\title{
ARROZ E COCA: ANÁLISE DE UMA EXPERIÊNCIA ENTRE COLONOS DO ORIENTE BOLIVIANO
}

\section{FIDEL OSCAR HOYOS BONILLAS}

Orientador: Prof. Dr. ORIOWALDO QUEDA

Dissertação apresentada à Escola Superior de Agricultura "Luiz de Queiróz", da Universidade de São Paulo, para obtenção do Titulo de Mestre em Agronomia, Área de Concentração: Economia Agrária.

\author{
PIRACICABA
}

Estado de São Paulo, Brasil

Novembro - 1992 
Ficha catalográfica preparada pela seção de Livros da Divisão de Biblioteca e Documentação - PCAP/usP

Hoyos Bonillas, Fide1 Oscar

H868a Arroz e coca: análise de uma experiência entre colo nos do Oriente Boliviano. Piracicaba, 1992.

$p$.

Diss.(Mestre) - ESALQ

Bibliografia.

1. Arroz - Aspecto político-sócio-econômico - Bolívia 2. Coca - Aspecto político-sócio-econômico - Bolívia I. Escola Superior de Agricultura Luiz de Queiroz, Piracicaba CDD 338.17318 
ARROZ E COCA: ANALISE DE UMA EXPERIENCIA ENTRE COLONOS DO ORIENTE BOLIVIANO

FIDEL OSCAR HOYOS BONILLAS

Aprovada em: $19 / 01 / 1993$

Comissao julgadora:

Prof. Dr. Oriowaldo Queda ESALQ/USP

Prof. Dr. Carlos Jose Caetano Bacha ESALQ/USP

Prof. Dra. Vera Marisa Henrique de Miranda Costa UNESP

\author{
Prof. Dr. ORIOWALDU QUEDA \\ Orientador
}


Aos meus pais pelo apoio moral, sentimental e material que sempre me ofereceram.

À minha esposa Margoth e aos meus filhos: Leomardo e Tomio

Alberto pela compreensăo e companhia.

$\grave{A}$ memória do meu filho Miguel Angel 


\section{AGRADEC IMENTOS}

A Escola Superior de Agricultura "Luiz de Queiró" e ao Departamento de Economia e Sociologia Rural por terem aberto suas portas e permitido usufruir da valiosa experiência na Area de Economia Agrária;

Ao Conselho Britânico por ter proporcionado os meios econômicos durante a realizaçăo do curso, e, em especial, à Sra. Rozanne M C L Zachetti pela atençao com que me brindou ao longa de minha permanência no Brasil;

Ao Centro de Investigación Agricola Tropical (CIAT) e à Missáo Britainica em Agricultura Tropical em Santa Cruz, Bolivia, pela oportunidade que me deram para aprofundar meus conhecimentos;

Ao Dr. Prof. Oriowaldo Queda, meu agradecimento especial nao so pela sua criteriosa orientaçă mas, tambem, pela sua qualidade humana e espirito solidario demonstrado nos momentos dificeis;

Aos Drs. Carlos José Caetano Bacha, Dalcio Caron e Manoel Cabral de Castro pelas criticas e sugestoes oportunas que contribuiram para o aprimoramento do presente trabalino;

A todos as meus colegas do curso, especialmente a Nelson, Newton, Pery, Weimar, Juvenal e Alfredo pela sincera amizade e companherismo que fizeram ainda mais grata minha estada no Brasil;

Aos demais profesores e funcionários do Departamento de Economia e Sociologia Rural. 


\section{INDICE}

PAGINA

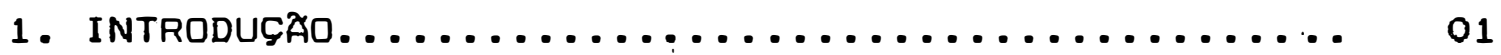

1.1 o problema.......................... 01

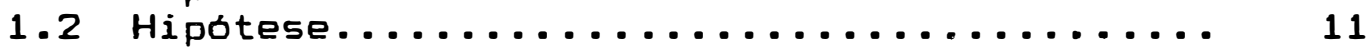

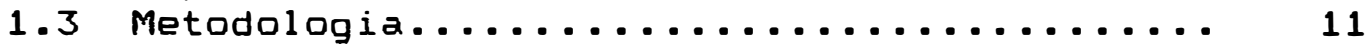

1.3 .1 Antecedentes.................. 12

1.3.2 Localizaçao geográfica e estrutura fundiária....................... 16

1.3.3 A escolha de Yapacani............. 18

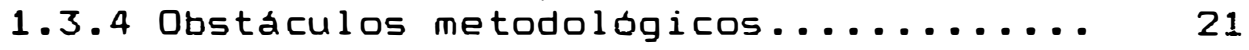

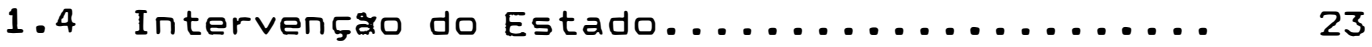

1.4 .10 planejamento................ 24

1.4.2 A "Estrategia de Desenvolvimento"... 26

1.4 .30 planejamento como processo de

intervençao racional............ 28

2. A CULTURA DA COCA..................... 33

2.1 Antecedentes da cultura da coca na Bolivia. 34

2.2 Breve historia da cocaina............. 37

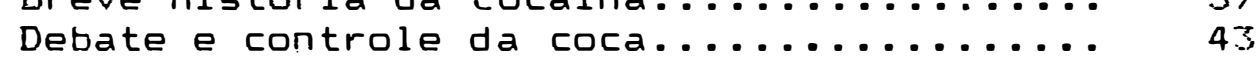

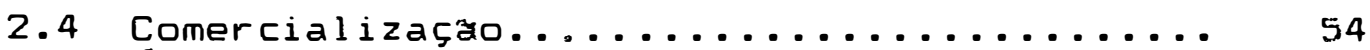

2.5 Areas de produçăo de coca............... 58

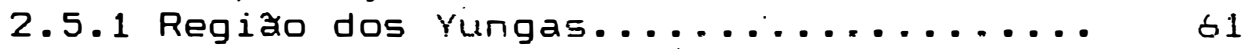

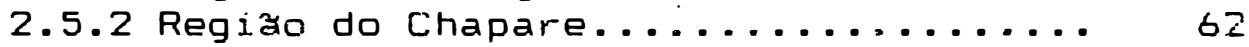

2.5.3 Regiao de Yapacani............... b2

3. O DESENVOLVIMENTO AGR FCOLA DO DEPARTAMENTO DE

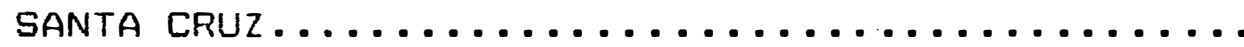

3.1 Antecedentes..................... 65

3.1 .1 o "Plano. Bohan".................. 66

3.1 .2 A Revoluçao Nacional de 1952........ 70

3.1 .3 A Reforma Agrária.............. 72

3.2 Evoluçao da estrutura agrária........... 74 
vi

PAGINA

3.3 Categorias sócio-econâmicas de produtores

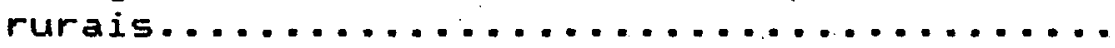

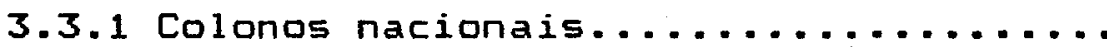
78

3.3.2 Empresários nacionais............. 83

3.3.3 Colonos estrangeiros............... 85

3.4 A situaçao atual dos colonos nacionais...... 86 3.4.1 0 arroz: cultura central nas unidades

produtivas...................... 86

3.4.2 A "crise do pousio" e a procura de

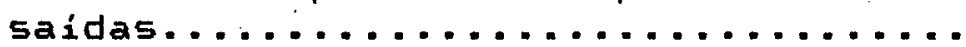

3.50 periodo 1978-1982: a crise politica e a economia da coca e seus derivados.........

3.6 Algumas prováveis conseqüencias da carência de "planejamento".....................

89

94

97

4. A colonta de YAPACANI........................... 101

4.1 Aspectos culturais da colonia de Yapacani.. 101

4.2 Arroz e Coca: opcao caotica perante a

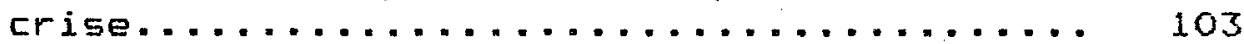

4.3 Desenvolvimento dirigido vs. desenvolvimento

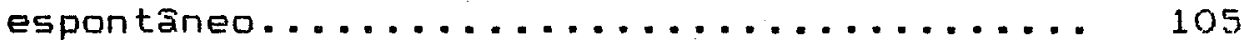

4.4 Resultados do Estudo Empirico............. 108

4.4:1 Estrutura da produção antes da erradicaçao................... 109

4.4.2 A marginalizaçåo dos nao-produtores

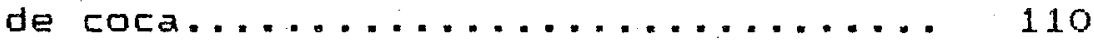

4.4.3 Renda do Capital na cultura da coca.. 4.4.4 Renda do Capital na cultura do arroz. 118 4.4.5 Dutras opcoes de produça.......... 119 4.4.6 Destino incerto do credito.......... 120 4.4.7 A oppao de continuar produzindo coca

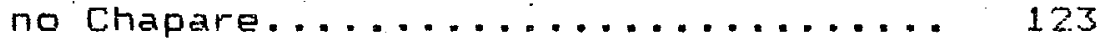

4.4.8 A dificuldade de erradicaça definitiva da cultura da coca....... 124

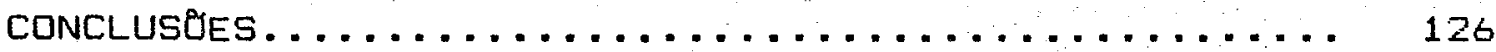

BIBLIOGRAFIA 133

APENDICE $1 \quad 139$

APENDICE $2 \quad 147$ 
TABELA 01. Exportaçao de coca boliviana, periodo 1902-1925...................

TABELA 02. Exportaçao de coca da Bolivia, periodo 1944-1948..................

TABELA 03. Volume e valor das exportaçoes da coca boliviana, periodo 1938-1952.....

TABELA 04. Volume e valor da coca boliviana exportada, periodo 1968-1976........

TABELA 05. Area de produçăo de coca na Bolivia, segundo regiao, periodo 1968-1987...

TABELA 06. Area, volume e participaçăo percentual das regibes de produça de coca,

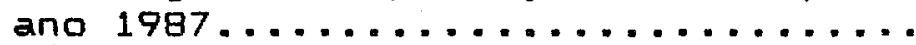

TABELA 07. Departamento de Santa Cruz: distribuicáo da populaçăo por Provincias..

TABELA 08. Evoluça dos preços da coca na Bolivia......................

TABELA 09. Familias da cidade de Santa Cruz segundo nivel de potreza, 1988.......

TABELA 10. Area media do arroz e da coca segundo sub-regides de Yapacani.........

TABELA 11. Precos medios da folha de coca na regiao do Chapare, periodo setembro/87 -

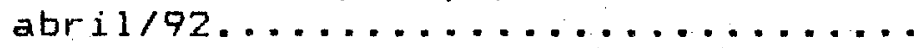

\section{LISTA DE QUADROS}

QUAADRO O1. Bolivia: exportaçaes e importaçoes,

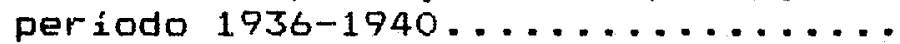

QUADRO 02. Cidade de Santa Cruz: evoluçao da populaçă, periodo 1900-1988. 
QUADRo oj̉. Renda do capital "com controle quimico"

PAGINA para a cultura da coca en Yapacani..

QUADRO 04. Renda do capital "com controle manual" para a cultura da coca em Yapacani..

QUADRO 05. Renda do capital para a cultura do arroz

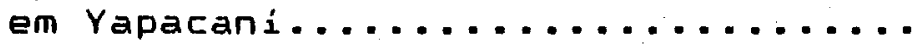

\section{LISTA DE TABELAS DQ APENDICE 1}

TABELA I.1. Santa Cruz: número e área das unidades agropecuarias por Provincia, segundo uso da terra..................

TABELA I.2. Provincia Ichilo: número e área das unidades agropecuárias por tamantio das propriedades sequndo uso da terra...

TABELA I.3. Evolução da populaçăo das áreas urbanas do Cantao Sáo Carlos, Provincia Ichilo,

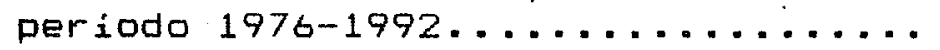

TABELA I.4. Santa Cruz: participaça no PIB nacional,

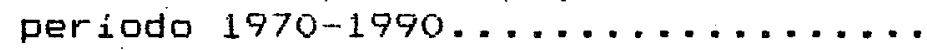

TABELA I.5. Preços do arroz e valor da diaria, periodo 1961-1989...............

TABELA I.6. Moradias segundo carencia de servicos básicos na cidade de santa cruz....

TABELA I.7. Populaçzo segundo niveis de pobreza; tamanho e renda média mensal, em dolares por familia e "per capita".. 


\section{ARROZ E COCA: ANALISE DE UMA EXPERIENCIA ENTRE COLONOS DO ORIENTE BOL IVIANO}

Autor: Fidel Oscar Hoyos Bonillas

Orientador: Prof. Dr. Driowaldo Queda

RESUMO

Este trabalho analisa o desenvolvimento do núcleo de colonizaçao, chamado Yapacani, conduzido por agricultores familiares'na regiao norte do Departamento de Santa Cruz, Bolivia. Este projeto nacional de colonizaça pretendia redistribuir a populaça camponesa boliviana visando aumentar a producao agropecuaria nacional. o projeto, a partir da decada de 1960, encorajou a migraço de camponeses, radicados no ocidente e carentes de terras, para as extensas áreas do oriente boliviano.

Com o aumento da producăo domestica foi possivel reduzir as importaçoes, atingindo um dos objetivos centrais dos planos de governo daquela epoca. No entanto, uma vez esgotado este modelo de substituiço de importaços, as diversas colonias assentadas no Departamento de Santa Cruz ingressaram numa crise, gerada pela reduça dos preços 
dos seus produtos, principalmente o arroz. No caso da colônia de Yapacani esta crise foi maior devido a fragilidade do seu solo, tornando-se praticamente inviável a melhoria tecnológica.

Surge, assim, na metade dos anos setenta, uma variável nao contemplada nem pelos planificadores nem pelos colonos: a demanda internacional por cocaina alterou os preços domésticos da folha de coca (materia-prima da cocaina), dando um estimulo extraordinario aos potenciais produtores.

Os solos de Yapacani, marginais para a cultura do arroz, se revelaram muito bons para a cultura da coca. Assim, paradoxalmente, foi a cultura da coca e nao os planos propostos pelo governo que permitiu á maioria dos colonos estabilizar seus sistemas de producaro. Com a renda gerada pela coca, a maioria dos colonos de Yapacani conseguiu iniciar a criaçao de gado bovino, diversificando e mel horando, assim, sua renda.

No entanto, diante das pressoes internacionais visando a reduça das plantaças de coca, no territorio nacional, o governo decidiu intervir novamente na colonia de Yapacani. Desta vez, através do uso do credito e da aça militar indireta. o proposito explicito desta nova 
intervençăo era $a$ de promover $a$ desenvolvimento autosustentado da colônia, mediante um programa de substiituiça da cultura da coca.

Esta dissertacao está sendo realizada dois anos após o inicio da execuçao do programa de erradicaçăo da coca, na colónia de Yapacani. Conseqüentemente, as mudanças ainda estao em curso nesta colônia. A renda gerada pela coca, para os colonos que optaram pela erradicaça voluntaria, foi substituida pela indenizaçăo e créditos. 0 problema era prever em que medida as investimentos feitos para substituir a coca permitiriam aos colonos um desenvolvimento auto-sustentado no longo prazo.

Os resultados deste estudo sugerem que, durante a nova intervençăo feita pelo governo, o principal objetivo foi a erradicaçao da coca e nå a promoçao de um verdadeiro desenvalvimento alternativo da colonia de Yapacani. Destarte, é previsivel que mais cedo ou mais tarde os colonos voltem a produzir coca. Para tanto, basta que a rentabilidade desta cultura permaneca elevaida e que faltem opgres viaveis do ponto de vista ténico, economico e legal para a maioria dos colonos. 


\section{RICE AND COCA: AN ANALYSIS OF AN EXPERIENCE INVOLVING PEASANTS IN EASTERN BOLIVIA}

Author: Fidel Dscar Hoyos Bonillas

Adviser: Prof. Dr. Oriowaldo Queda

SUMMARY

This research analyses the development of the settlement nucleus called Yapacani, conducted by family farmers in the northern region of the Santa cruz Departament, Bolivia. This national colonization project intended to redistribute the Bolivian peasant population whith the aim of increasing the national agricultural production. From its inception inthe sixties, the project encouraged landless peasants living in the western region to move to extensive areas in eastern Bolivia.

The increased domestic production enabled a substantial reduction. in imports, which was one of the main objectives of the governmental plans at that time. However, once this import substitution model was exhausted, the various colonies settled in the Santa Cruz Departament faced 
a crisis caused by a decline in prices of their products, mainly rice. In the case of the Yapacani colony, the crisis reached greater proportions since the poor soils made technological improvements practically impossible.

A variable not anticipated by planners or peasants came forth in the mid-seventies: the international demand for cocaine altered domestic prices for coca leaves (raw material for the production of cocaine). This resulted in an extraordinary stimulus for potential producers.

The Yapacani soils wich were marginal for rice production proved to be quite suitable for coca cropping. Thus, paradoxically, it was coca cropping rather than the plans proposed by the government that enable most of the peasant to stabilize their production system. With the income generated by coca most of the Yapacani peasants started raising cattle, thus diversifying and improving their income.

However, in view of the international

pressure for reducing coca cropping in the national territory, the government decided, once again, to intervene in the Yapcani colony this time by garanting credit and using indirect military action. The explicit purpose of this 
new ention was to promote the self-sustained development of the colony by implementing a coca replacement program.

This dissertation is being conducted tho years after the inception of the coca erradication program in the Yapacani settlement. Consequently, the changes are still underway. The income generated by coca for peasants who chose to voluntarily eradicated that crop was compensated by granting indemnity and credit. The problem faced was to predict to what measure the investments made to replace coca would enable a long term self sustained development for peasants.

This study suggest that the main objective of the latest government intervention was the eradication of coca rather than the promotion of real alternative development of the Yapacani settlement.

Thus, it is predictable that, sooner or later, the peasants will resume their coea cropping activities. For this, it is only necessary that the profitability brought by this crop remain high and the feasible alternatives, from the technical, economic, and legal point of view, are not available to most of the settlers. 


\section{LISTA DE ABREVIATURAS}

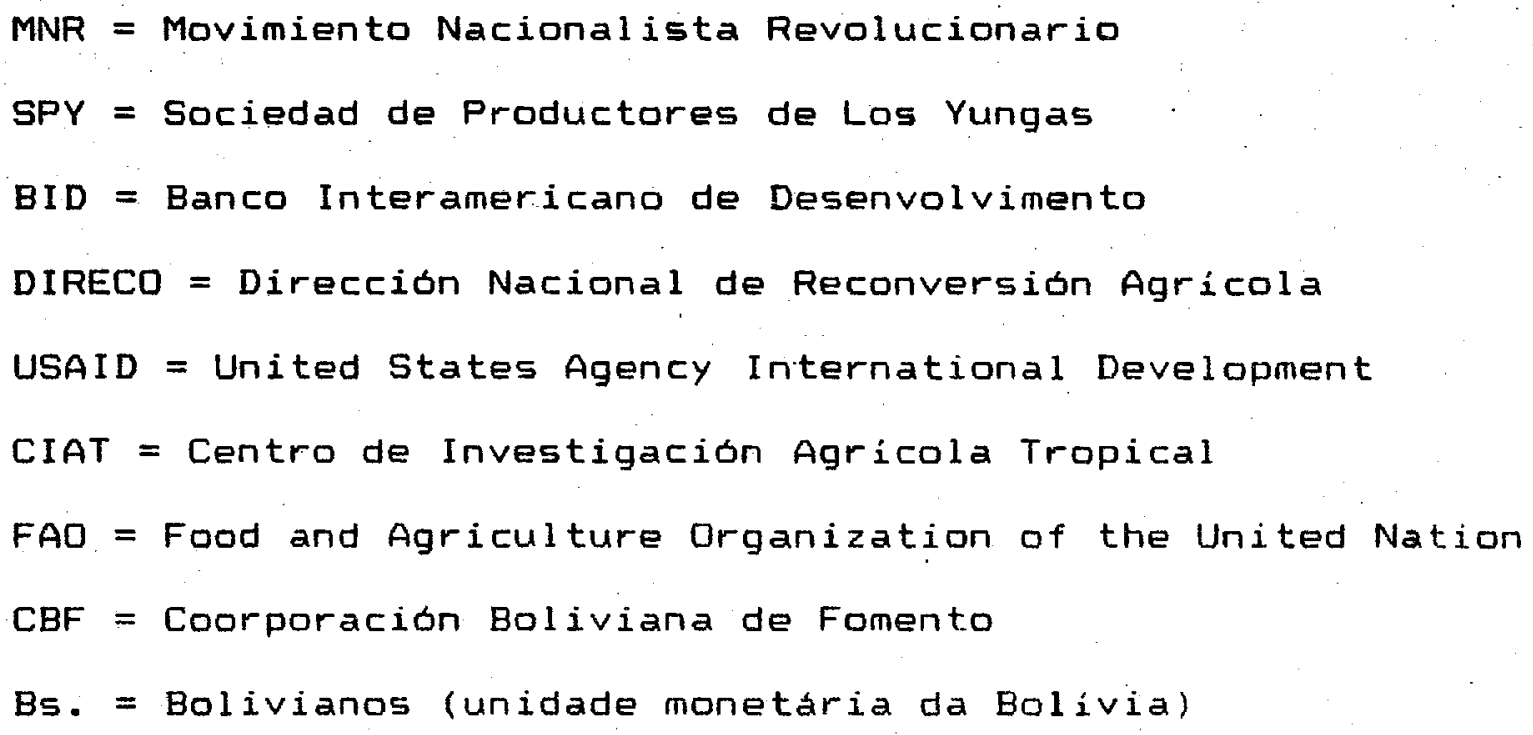




\section{INTRODUÇÃo}

\subsection{O problema}

Em 1952, ano da Revoluça Nacional e da tomada do poder pelo Movimento Nacionalista Revolucionario

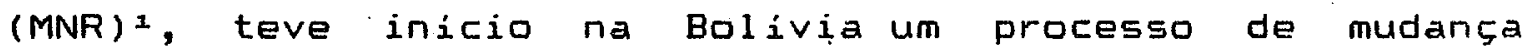
estrutural de significativa importancia historica, politica, social e económica para o pais. o novo Estado de 1952 renquadrado no modelo latimo-americano de capitalismo dependente) pretendia conduzir o pais a uma melhor integraçao aos novos padroes da modernizaço diante da hegemonia norte-americana, depois da Segunda Guerra Mundial. En 1942, a sociedade boliviana manifestava uma rigidez na sua estrutura produtiva e de poder. Essa rigidez foi salientada pela Missáo Norte-americana ao fazer um diagnostico da economia boliviana daquela épocas. Este trabalio apontou o obstáculo que significava, para o

1 Partido policlassista fundado en 1941. Foi o promotor da Revoluça de 1952 e adquiriu grande popularidade depois de decretar a Hacionalizaçao da Mineraçăo, o Voto Universal e a Reforma Agrária.

z Esta Missaro foi presidida por Merwin Bohan. O Informe apressentado ao governo pela Missao, que passou a ser conhecido como "0 Plano Bohan", teve grande influencia nas estrategias, planos e projetos do Estado boliviano a partir de 1952. 
desenvolvimento das forças produtivas do pais, a excessiva concentraçao da atividade económica e do poder politico na área da mineraçăo.

Baseado nestas premisas, o Estado de 1952 criou as condiçoes para uma maior participaçăo mobilizaça da populaçăo camponesa no mercado de trabalho e de produto. Esta permanecia, até entao, en condiçăo de servilismo nos latifundios e nas comunidades3 tradicionais dos al tiplanos. Praticava-se uma economia de subsistencia precaria, com poucas possibilidades de formaçao de capital, devido aos serios problemas de escassez de terra (minifúndio) e a concentraçă da renda, que ocasionavam uma baixa demanda efetiva por bens de origem agropecuaria.

Como medidas imediatas o Estado decretou a Nacionalizaçao da Mineraça (em 1952) e a Reforma Agrária (em 1953). Estas medidas foram complementadas com a construça da estrada Santa Cruz-Cochabamba que i igou o Oriente e o Ocidente bolivianos, assentando-se assim as bases para a execucao posterior do Projeto Nacional de Colonizaça.

Feita a ligaça dos Altiplanos e Vales interandinos com as planicies tropicais, teve inicio um processo de colonizaça daregiao norte doDepartamento de Santacruz".

- Entende-se por "comunidade" uma concentraçăo de povoadores nativos en certas areas impostas pela Coroa espanhola, por motivos de segurança. No entanto, nela coexistem elementos das comunidades preexistentes no Pera (ayllu) e no Mexico (calpulli) com outros originários da Espanha (FURTADO 1978, p:19).

4 Nome genérico pelo qual é conhecida a açzo do governo de fomento as migraçaoes do altiplano, vales e também do exterior (Canada e Japao), principalmente para o Departamento de Santa Cruz. Este foi o mecanismo 
Entre os objetivos explicitos mais importantes dos planos governamentais, contidos na estratégia do novo Estado de 1952 , temos: a) a substituiçao de importaçöes de produtos alimentares de origem agropecuária, suscetiveis de serem produzidos na regiao do Oriente boliviano, principalmente no Departamento de Santa Cruz, onde, ao contrário do Altiplano e Vales inter-andinos, a terra era abundanteo; b) melhorar as condiçôes de vida da maioria camponesa através de sua incorporaçăo ao mercado.

Nao obstante, por causa de diferentes circunstancias politicas, sociais e economicas, os objetivos do governo so foram atingidos parcialmente. No ambito das colonias nacionais assentadas no Departamento de Santa Cruz, os frágeis suportes institucionais, a marginalizaçăo da grande maioria dos camponeses no acesso aos serviços de credito e assistencia técnica, e a rapida saturaçao do mercado domestico, entre outras causas, deram lugar a entraves tecnológicos dificeis de serem superados pelos agricultores colonizadores. Estes, alem das dificuldades

utilizado para asmentar um grande namero de produtores agropecuarios naquele Departamento.

- De acordo com a oivisao politico-administrativa, a Bolivia está dividida en nove Departamentose estes, por sua vei, se dividen em Provincias. Departamentos e Provincias equivalem a Estados e Municipios, respectivamente, no sistema federalista brasileiro.

- Cabe esclarecer que, no Oriente boliviano ainda que abundante, a terra nem sempre estava livre. Dai, a necessidade da Reforma Agrária para viabilizar a colonizaçăo desta regiăo. 
descritas acima, defrontavam-se com um ambiente tropical desconhecido e que exigia uma série de importantes mudanças tanto mas técnicas de produçao quanto na própria alimentaça e no vestuário.

Desta maneira, a maioria dos colonos nacionais, assentados na regiao norte de Santa cruz, simplesmente passou de uma situaçăo de servilismo ou minifúndio fisico no altiplano e vales, prevalecente arites da Revoluçao do 52, a uma situaçă de minifúndio técnico? no tropico.

Esta situaçao passou a constituir um grave problema econamico, social e ecologico. É que, devido as 'dificuldades de estabilizaçao de suas unidades de produçao, os colonos optaram pela pratica da clásica agricultura itinerante ou emigraram as cidades proximas, agravando o problema urbano do desemprego e marginalidade social ja existente.

Conscientes deste problema, muitas instituiçoes governamentais e nă-governamentais empreenderam diversos esforcas com o objetivo de consolidar

7 Entenda-se por esta analogia o seguinte: a insuficiencia de recursos técnico-financeiros, da maioria dos colonos nacionais, passa a constituir um gargalo que inviabiliza uma utilizaçao maior da terra (mesmo sendo esta relativamente abundante) na area de colonizaçao (onde as parcelas tem uma área de 20 a $50 \mathrm{ha}$ ) com relaça a área no lugar de origem (ande as parcelas, na maioria dos casos; tem uma área de 0,1 a 3 hal. Sem acesso a tecnologia moderna só é possivel utilizar no máximo $10 \%$ da terra possuida, mediante a prática de uma "agricultura itinerante" a qual, segundo BOSERUP (1987, p.13), é comum nas áreas de baixa presszo demografica da América-Latina, África e algumas partes da Ásia. 
estas colonias. Procurava-se evitar tanto uma maior deterioraço social e economica dos colonos, quanto a pressao que estes exerciam sobre a expansăo da fronteira agricola e na periferia da cidade de Santa Cruz.

Entretanto, juntamente com estes esforços institucionais, surgiu uma variável imprevista tanto pelos planificadores quanto pelos próprios colonos: a elevaçao da demanda internacional de cocaina (cloridrato de coca). Esta atraiu capitais internacionais e empresários propensos ao risco, dando lugar a criação de uma poderosa rede de narcotráfico que opera, desde entăo, em diversos paises do mundo.

0 capital do narcotrafico encontrou na crise economica boliviana uma conjuntura altamente favorável para se desenvolver. Rapidamente, foram estabelecidos os mecanismos necessarios para estimular o fornecimento de materia-prima - das áreas deproduça tradicional de coca pelos camponeses, para a elaboraço de pasta básica e cocaina.

Uma outra variável, de grande importancia, foi o aspecto cultural. Como e sabido, o habito de mastigaçao da folha de coca tem raizes milenarias na populaçăo de origem andina. Ela se constitui praticamente em simbolo de identidade cultural. Assim, os colonizadores da regiao norte de Santa Cruz, provenientes das montantias e vales inter-andinos da Bolivia, continuaram com este hábito 
no trópico. Mesmo sendo a coca uma mercadoria comercializada legalmente no mercado, desde a epoca Colonial, a preços competitivos, a maioria dos colonos preferiu nao cultiva-la na sua propriedade.

No caso da colonia de Yapacani lobjetivo do estudo), a coca era cultivada por alguns agricultores desde - inicio deste assentamento. Isto foi devido a fatores climatologicos e edáficos favoráveis e, principalmente, pela influência da vizinha regiao do Chapare (maior centro produtor de coca na Bolivial. Mesmo assim, nesta fase, a cultura da coca era conduzida em pequena escala, principalmente para o consumo pessoal.

A elevacáo do preço da foltia de coca no mercado doméstico, provocada pela crescente demanda das unidades de processamento industrial clandestinas, instaladas na regiao, coincidiu, no ambito da colonia Yapacani, com a deterioraçao dos rendimentos da cultura de arroz, principal fonte de renda monetaria destes colonos. Como consequencia disso, a opçao de produzir mais coca passou a ser a decisao mais logica. Ainda mals se levarmos em conta que, até 1988 , nå havia no pais proibiçăo legal explicita para a plantaçao de coca. A proibiçao existente estava limitada a produçăo de pasta basica écocaina, nå sendo extensiva para a coca (artigos 9, 10 e 11, Titulo Primeiro, Cap. Primeiro da "Ley del Regimen de la coca.y sustancias controladas, 1988). 
Portanto, verifica-se que os colonos de Yapacani tiveram, ao longo do periodo de assentamento e consolidaçao desta colônia, duas propostas de açăo. Primeiramente, um plano de governo que os induziu (explicita e implicitamente) a produçăo de arroz e a fornecer força de trabalino a agricultura empresarial, so que com deficiente apoio en termos de suporte institucional, canais de comercializaçao, fornecimento de insumos e unidades de processamento industrial, que facilitasse o objetivo relacionado a produça.

Posteriormente, depois de esgotado o modelo de substituiçao de importaçoes (pelo menos no que se refere ao arroze a cana-de-açúcar), os colonos foram deixados expostos as "forcas de mercado". No entanto, aproximadamerite a partir da segunda metade da decada dos setenta, aconteceu um fenameno singular na Bolivia. O preço da folna de coca elevou-se consideravelmente no mercado doméstico. A causa fol a proliferaça de unidades de processamento industrial que transformavam a coca em cocaina. Esta producăo era destinada a satisfazer a crescente demanda deste produto no mercado internacional (principalmente EUA e Europa). O caráter ilegal desta atividade economica, que passou a ser denominada "narcotrafico", tornou ainda mais elevados os preços da follha de coca. Esta tornou-se inclusive um artigo fora das possibilidades econômicas dos camponeses ccisumidores, mas nao-produtores, de folha de coca. Isto significou um alto custo social dado que este produto é 
tradicionalmente considerado uma mercadoria básica na Bolivia..

No entanto, a oferta da coca mostrou ter uma alta elasticidade-preço (E) (E=17,6); em apenas 12 anos, a area plantada passou de 4.450 ha em 1971 para 60.956 ha em 1987 (cf. tabela 05, p.59) apesar da interferência de forças repressoras, tanto nacionais quanto internacionais. Isto fez com que o preço da coca, que passou de \$US 0,86 (estimado da tabela 08, 0.93 ) a \$US 1,58 neste periodo, voltasse a ser acessivel para os consumidores tradicionais bolivianos nos anos seguintes (cf. tabela $11, p .117$ ).

Este comportamento da oferta é claramente compreensivel do ponto de vista ecomómico. Us colonos, sujeitos do estudo, foram induzidos pelo mercado a introduzir ou a ampliar a area da cultura da coca: era esta a cultura que oferecia maiores margens de lucratividade, alem de ser uma cultura de baixa exigência de capital e conhecimentas tecnalogicos adicionais. Tampouco deve ser esquecido o fato de que era preciso, também, satisfazer as necessidades de autoconsumo de coca diante da súbita elevaço dos preços desta mercadoria no mercado.

Este inusitado fenómeno, que ainda continua afetando o desenvolvimento da colônia Yapacani, revela uma série de contradiçoes da politica econômica do governo. Comparando os objetivos explicitos e implicitos dos planos

- Ainda hoje, é freqüente que uma raçà de aproximadamente uma cinça de folhas de coca ( $38 \mathrm{gr}$ ), por dia de trabalho, faça parte do salário dos peơs nas fazendas da regizo do Chaco boliviano. Em outras regiaes, onde nao é comum esta modalidade, a coca é comprada pelo próprio trabalhador. 
de desenvolvimento executados antes do "auge da coca" com o tratamento diferenciado que atualmente recebe a colónia; vemos que houve simultaneamente uma mudança radical e contraditoria: os atuais planos de desenvolvimento alternativos resultaram numa espécie de prêmio aas supostos delinqüentes (produtores de coca en regibes declaradas ilicitas) e uma penalizaça aos supostos inocentes (agricultores que nunca produziram coca), devido a marginalizaçă destes ao processo.

Uma outra situaçao paradoxal tem a ver com o objetivo, expresso nos anteriores planos, de incorporar os colonos ao mercado. No entanto, justamente quando estes agricultores dao clara evidencia de sensibilidade, diante dos estimulos de precos, o governo viu-se obrigado a intervir - inclusive usando metodos coercitivos - nas decisoes destes colonos. a objetivo e evitar que eles obedecessem as sinalizaçoes que ainda apontam a coca como a cultura que mais responde a racionalidade economica.

Contudo, mesmo tomando medidas coercitivas, tudo indica que o problema da "coca excedente" em Yapacani, e no resto do pais, ainda está longe de ser resolvido.

Diante dos fracassos dos multiplos esforcos do governo na eliminaça deste problema, no minimo cabe

9 Chama-se "coca excedente" a produço de coca que se considera que é destinada principalmente a elaboraçăo de cocaina. Consequentemente ela e ilicita. 
formular a seguinte pergunta: será que as soluçoes propostas estao partindo de um diagnóstico certo?.

Assim, acreditamos que para entender melhor este problema, é aconselhável conduzir uma análise que inclua as múltiplas variáveis que direta ou indiretamente estao relacionadas com 0 aumento da produçăo de coca na colonia selecionada para este estudo. Neste sentido, a presente pesquisa tentara dar respostas as seguintes perguntas:

1. Quais os fatores históricos, politicos, sociais, culturais e económicos que explicam o aumento da cultura da coca mas unidades produtivas dos colonos de Yapacani, nos ultimos 15 anos?

2. Qual o grau de eficiencia do governo na execuçáo do plano de desenvolvimento proposto aos colonos?

3. Quais as implicaçøes do programa de erradicaça da coca na colônia de Vapacani para a vizinha regiao do Chapare? 


\subsection{Hipátese}

- fenameno do aumento da produçao de coca, na colónia de Yapacani, a partir dos últimos 15 anos, é uma conseqüencia lógica da irracionalidade, parcialidade e falta de continuidade con que foi encarada a "funça de plamejamento" por parte do. Estado boliviano.

\subsection{Metodologia}

- presente estudo analisa o processo de desenvolvimento socio-economico da colónia de Yapacani, localizada no Departamento de Santa Cruz. Esta colonia e fruto da execuço de un plano do governo, a partir da Revoluçao Nacional de 1952, que como foi visto acima, constituia intento deliberado para mudar a realidade socioeconômica boliviana.

Enquanto a organização do trabalio, temos neste primeiro capitulo a definiço do problema, a hipotese e a metodologia utilizada. Também se inclui nesta introduça, o marco teórico do estudo. a segundo capitulo tem a finalidade oe esclarecer ao leitor nao familiarizado com a cultura andina alguns aspectos historicos, culturais, politicos e económicos referentes à cultura da coca.

No terceiro capitulo, se descrevem as mudanças politicas e económicas acontecidas no pais e o papel do Estado como ente planificador do desenvolvimento da sociedade boliviana, a partir da decada de 1950. Também 
neste capitulo se faz uma caracterizaçao dos diferentes grupos de agricultores do Departamento de Santa Cruz e se analisam as circunstancias socio-econamicas dos colonos do oriente boliviano em geral.

No quarto capitulo, a análise é focalizada na Colônia Yapacani. Aqui sao descritas com maior detalhe as circunstâncias que rodeiam os colonos de Yapacani e sao apresentados os resultados do trabalino de campo. Finalmente, com base neste e nos capitulos anteriores sao formuladas e apresentadas as conclusôs do estudo.

\subsubsection{Antecedentes}

A partir dos primeiros anos do presente século, durante a presidência de Jose Manuel Pando, a area compreendida entre Yapacani e Porto Grether foi considerada como "area de: colonizaça". O interesse da Bolivia em patrocinar programas de assentamento e colonizacao, em geral inviaveis naquela epoca, obedecia aos constantes problemas limitrofes com os paises vizinhos e que motivaram perdas territoriais importantes. Ficava evidente o frágil dominio que 0 Estado boliviano exercia sobre suas fronteiras amazonicas e o virtual isolamento das extensas "planicies tropicais" (FIDER 1976, citado por ABREGO et al1i 1990, P.12).

Segundo DANLLER (1984), foi a partir da perda territorial do Chaco, no conflito belico com o Paraguai (que 
ocorreu no periodo de 1933 a 1935), que o Estado procurou, com maior decisao, al ternativas de integraçă do Oriente com o Dcidente do Pais. Tem inicio, entao, alguris projetos de colonizaça e liberaçă de grandes extensbes de terras que, em geral, nao foram exploradas.

o primeiro intento sério de colonizaçăo, na provincia Ichilo (Departamento de Santa Cruz), de acordo com MANZANO (1964), teve inicio em 1937 com o assentamento "German Bush" constituido por 40 ex-combatentes da Guerra do Chaco. A cada colonizador foram cedidas glebas de 50 ha localizadas en ambos os lados do chamado "caminho central" que une Yapacani a Porto Grether.

Em 1940, segundo este mesino autor, ja haviam sido assentados 200 colonos; a maioria deles de origem oriental e ex-combatentes da guerra. Mas, a falta de uma politica de apoio, por parte do governo, inviabilizou esta tentativa de assentamento. Foi assim que em 1950 so moravam 20 familias mesta colónia. A causa do exodo, da maioria das familias, foi que a partir de 1945, o exercito deixou de fornecer provisoes, apoio técnico, administraça e apoio na comercializaçao para os colonos. Uma outra causa de abandono foi a falta de uma ponte sobre o rio Yapacani que facilitasse o transporte e comercializaçă da produço da colônia (MANZANO op cit).

Entretanto, como será visto no capitulo 3 , as idéias impressas no chamado "Plano Bohan" já começavam a ter 
eco nos circulos politicos e acabaram por se constituir nas bases da politica econômica do partido gestor da Revoluça Nacional de 1952, - MNR. Assim, um dos componentes da estrategia de desenvolvimento, posta em pratica pelo MNR, foi a "marcha para o Oriente" atraves da politica de deslocamento da populaçao e assentamentos de colonos, na regiao norte do Departamento de Santa Cruz.

Na base desta politica agraria foram feitos grandes esforcos para converter esta regiao em um polo de desenvolvimento economico macional. Apesar disso, o passar do tempo revelou que os objetivos implicitos desta politica acabaram levando a marginalizaçao da grande maioria de colonos migrantes dos serviços de assistencia social, técnica e econônica. Foram criadas assim as circunstâncias para o que viria a acontecer posteriormente (nos ultimos 15 anos, aproximadamente) na colónia de Yapacani.

En 1961 foi elaborado o "Plano Nacional de Desenvalvimento Económico e Social 1962-1971" que contemplava a migracăo de cem mil familias as regiojs tropicais do pais, atraves de um programa de colonizacăo semi-dirigida. Na epoca, segundo NELSON (1973), era um dos maiores da América Latina. A execuça destes planos teve inicio em 1962 sob a direçao da Corporaça Boliviana de Fomento (CBF), encarregando-se destes programas, em 1965 , o Instituto Nacional de Colonizaça (INC).

De acordo com ARRIETA et alli (1990), a abertura das estradas, tanto interdepartamentais como de 
penetraço na regiao Norte do Departamento de Santa Cruz e a conclusáo da ferrovia com o Brasil e com a Argentina, propiciou o rápido crescimento do fluxo de migrantes.

Diante desta situaçao"... o. Banco InterAmericano de Desenvolvimento (BID) concedeu em 1963 dois empréstimos de 6,5 e 2,6 milhoes de dolares a CBF, para a execuçăo de um Plano Decenal de colonizaçao semi-dirigida. o Plano consistia no assentamento, a partir do Altiplano, de 8.000 familias num periodo de 2,5 anos, das quais 2.500 estavam destinadas a Yapacani" (NELSON op cit, p.105).

Desta maneira, na area de Yapacani, a CBF iniciou em 1966, conjuntamente com o exercito, um programa de recolonizaçao e de melhoramento do caminho central da colonia. Os objetivos, segundo o citado aütor, foram:

1) Unir as populaçôs de Santa Cruz-Yapacani-Porto

Villarroel-Villa Tunari-Cochabamba;

2) propiciar o desenvolvimento agropecuário;

3) estabelecer empresas madeireiras.

A área de colonizaçăo de Yapacani foi parcelada de modo que as propriedades individuais tomaram a forma de "teclado de piano", cam lotes de 20 a 30 hectares. No entanto, quando o projeto estava en andamento, percebeuse que os cálculos sobre a capacidade do solo estavam errados. Grandes áreas que se achavam. aptas para producan de bananas e outras culturas resultaram viaveis so para a criaçao de gado em parcelas de 50 ha. Foi assim que em 1970. 
alguns colonos pediram ao INC uma compensaço de 30 hectares adicionais a área inicialmente cedida. Eles alegavam a escassa quantidade de vegetaça original para a produça de arroz, em sistema de pousio, na parte sul e a má drenagem do setor Norte. Essa solicitaça, en muitos casos, foi atendida (NELSON, op cit).

Nåo obstante, o projeto conseguiu assentar 3.604 familias, mas este número foi diminuindo na medida em que o apoio institucional reduzia. Assim, ao termino de alguns anos, $32 \%$ das familias (ou 1.157 familias) haviam abandonado a colônia (CASTILLO e CAMPEN, 1981). De acordo com. BLANES et alli (1984) citado por THIELLE (1990, p.29), em algumas áreas os abandonos aconteciam devido as inundaçees. Entre 1964 e 1970, o projeto reportou que $39 \%$ dos que chegavam, abandonavam, mencionando como causas deste fenâmeno: i) falta de vias de acesso transitáveis, ii) terra nao apta para agricultura, e iiil falta de água potável.

1.3.2. Localizaçăo geográfica e estrutura fundiária

A colônia de Yapacani está situada a $130 \mathrm{~km} \mathrm{a}$ Deste da cidade de Santa Cruz (ver mapa 1), no Cantao Sao Carlos, da Provincia Ichilo, do Departamento de Santa Cruz. Ela se localiza entre os paralelos $17^{\circ} 1^{\prime}$ e $17^{\circ} 22^{\circ}$ latitude Sul, ertre os meridianos $63^{\circ} 40^{\prime}$ e $64^{\circ} 23^{\circ}$ de longitude Qeste do meridiano de Grenwich, a uma altitude de 280 metros acima do nivel do mar. 
A área abrange desde a localidade de Santa Fé (km 0) ate Porto Grether ( $\mathrm{km} \mathrm{60),} \mathrm{ocupando} 49 \%$ da superficie da provincia (1.423.000 ha). Para fins administrativos divide-se em três sub-areas: "faixa norte", "faixa central" e "faixasul".

De acordo com o segundo e último: Censo Nacional Agropecuario de 1984 (o primeiro foi realizado em 1950, quando nao existia a Erionia de Yapacani), na Proviticla Ichilo existiam 4.605 unidades agropecuárias; $11 \%$ do total departamental. Aquelas unidades agropecuarias abrangiam 220.263,69 ha, ou seja 4\% da area do Departamento de Santa Cruz, com uma media de 48 ha por unidade agropecuaria, enquanto a area media das unidades agropecuarias do departamento era 130,5 ha.

Do total da area da Provincia, 48\% 520 utilizados com agricultura, ocupando o primelro lugar (com $17,33 \%$ ) en termos da area agricola total do Departamento de Santa Cruz (ver tabelas I.1 e I.Z, no apendice 1 ).

A colonia encontra-se lóalizada ra regiao ecologica denominada "bosque umido tropical", com uma temperatura media de $24^{\circ} \mathrm{C}$ e uma precipitacao média anual de $3000 \mathrm{~mm}$. A "faixa central" e plana e atualmente encontra-se totalmente desmatada. Na "faixa sul" a topografia e acidentada; existem pontos que apresentam entre 5 e $40 \%$ de inclinaçæo, apresentando afloramonto de pedras em diversas partes da superficie. A "faixa norte" apresenta problemas de inundacao durante boa parte do ano (Hoyos et al1i, 1987). 


\section{Das três sub-áreas da colônia, a "faixa} central" e a "faixa sul" sao as mais dinamicas em termos de produçao e comercio. A recente construçao da estrada Chimore-Yapacani, que liga as cidades de Cochabamba e Santa Cruz, propiciou novos atrativos para a populaço migrante.

No recente censo populacional realizado em junho de 1992, o Cantao Sao Carlos da Provincia Ichilo foi a localidade de Yapacani que experimentou a maior taxa de crescimento entre no periodo $1976 / 1992$ (ver tabela I.3, no apêndice 1). Isto confirma o grande dinamismo da colonia durante o periodo en que a cultura da coca foi importante fator de atraçao de colonos.

\subsubsection{A escoliha de Yapacani}

Em primeiro lugar, convem esclarecer que a colonia de Yapacani nao constitui un caso representativo da. Bolivia e tampouco do Departamento de Santa Cruz. Ela foi selecionada por uma serie de aspectos que, na opiniao do autor, sao de interesse nao so individual mas tamben comuniterio, nacional e internacional..

O interesse individual surgiu por causa dos vínculos. profissionais com esta colonia. o autor foi responsável pela elaburaçao de diagnósticos socio-económicos para o planejamento de pesquisas agricolas a serem realizadas nesta localitade. Dadas as múltiplas e.idencias da presença da cultura da coca, embora nao suscetiveis de 


\section{MAPA 1. LOCALIZAÇÃO DAS ÁREAS DE COLONIZAÇÃO NACIONAL NO DEPARTAMENTO DE SANTA CRUZ, BOLIVIA.}

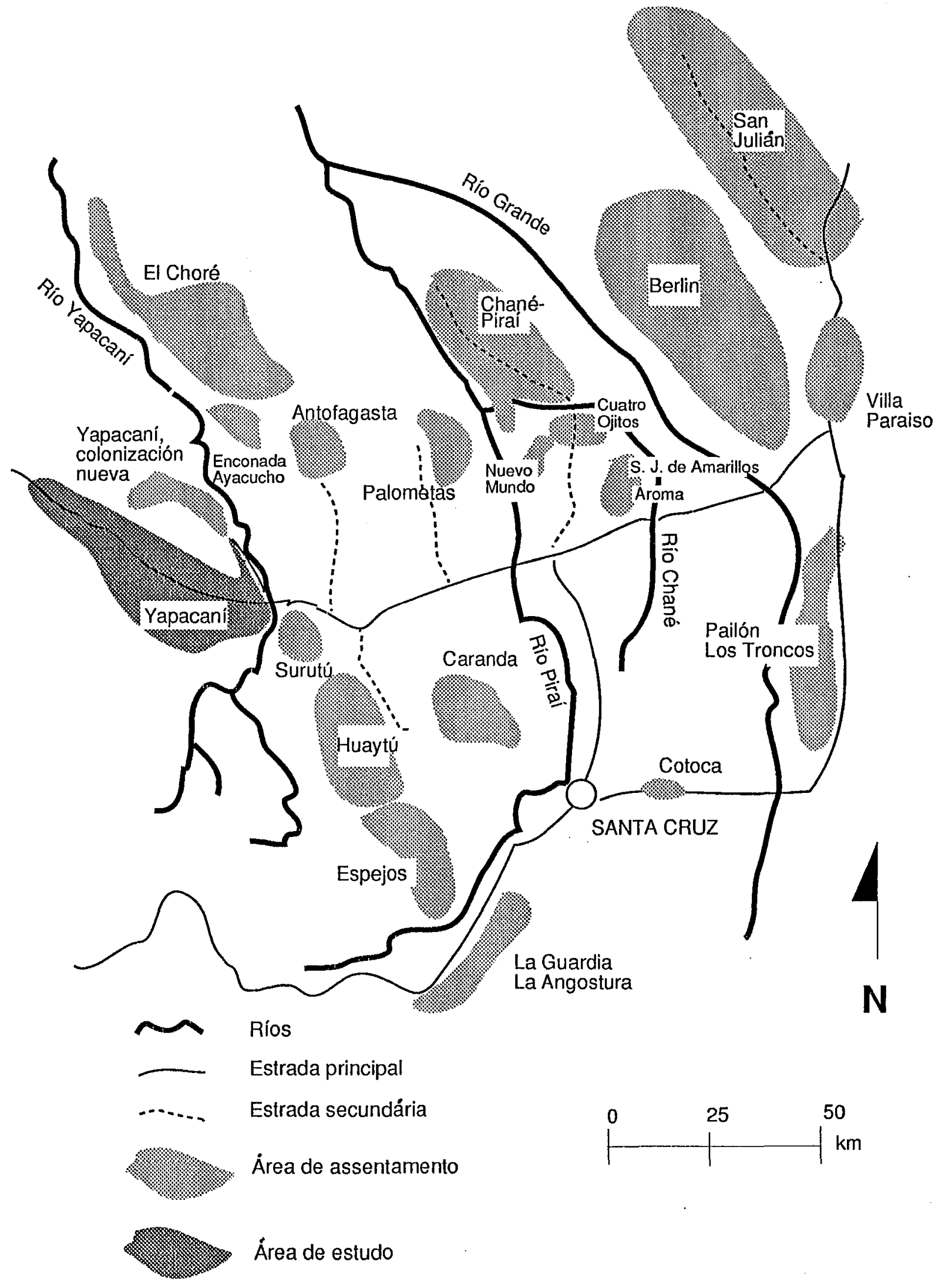


verificacko objetiva, resultava cada vez mais dificil entender as mudanças sociais, económicas, tecnologicas, culturais, etc. que estavam acontecendo nesta colonia.

$$
0 \text { interesse comunitario leva em conta que o. }
$$
trabalho do autor, nesta colônia, nao teria sentido se se limitasse a apresentaçao de informes carentes de conteúdo social e solidário. Deve ser enfatizado, também, que o argumento que defende ser inviável a realizaçao de um estudo. quantitativo do problema, nao justifica deixar de levar em conta as tendencias perigosas de desenvolvimento da colonia. Sera que a interpretaçao da realidade e somente possivel na presença de informaçao quantificavel? Se for assim, o pais estaria diante de um obstaculo permanente e de grande magnitude, enquanto a cultura da coca permanecer "proibida".

o interesse nacional esta no fato de que a experiencia de erradicacao de coca na colonia de rapacani, embora represente apenas $2 \%$ da produçao nacional, constitui a primeira experiencia na Bolivia. Os resultados desta experiencia sem dúvida serao de grande importancia para o tratamento da regizo do Chapare. Nesta regiao, onde se produz $90 \%$ da coca boliviana, o programa de erradicaça forçada está previsto para julho de 1993.

o inteiesse internacional se deve a que boa parte do problema é comum en diversos paises do mundo, mudando talvez só o cenário e os atores. Assim mermo, este problema tem a ver, embora de modo tangencial, com a grande 
preocupaçå mundial existente na atualidade decorrente do abuso dos consumidores e produtores de cocaina; os primeiros tentando maximizar seu bem-estar e os segundos tentando maximizar o seu lucro.

Finalmente, de modo mais direto, os acontecimentos registrados nesta colónia, ao longo de sua relativamente curta existência, revelam os perigos potenciais insuspeitados que podem existir quando se executam planos e projetos de desenvolvimento econámico sob uma ofica excludente. Isto é, quando na se considera o inter-relacionamento das múltiplas variáveis endogenas e exógenas que entram em jogo na hora de alterar, através de planos e projetos, o curso da realidade de uma comunidade, de um pais ou de uma regia.

\subsubsection{Obstáculos metodológicos}

Vale a pena salientar que o discurso oficial, onde o termo "marcotrafico" e utilizado habilmente para simplificar excessivamente a realidade, deu uma visao unidimensional a criminosa a um fenomeno extremamente complexo, com o simples proposito de justificar a aça repressiva como única soluça. Esta ir.tervençao criou uma serie de contradiçoes nas leis bolivianas. Por exemplo, dependendo da localização de suas plantaçoes, us produtores de coca sao ou nao sao considerados delinquentes.

Um obstáculo metodologico, decorrente do anterior, esta relacionado precisamente com o problema de 
dados na hora de se fazer uma analise quantitativa. A proibiço legal da cultura da coca na colónia de Yapacani, embora vigente desde 1988, foi aplicada apenas em julho de 1990; a partir desta data o agricultor que tinha plantas de coca nesta colónia passou a ser considerado delinqüente pelas leis bolivianas. Nestas circunstancias, obviamente resulta dificil, quando nao inviável, fazer um estudo empirico com pretensoles de rigor cientifico.

Nao obstante, considerou-se que esse obstáculo nao poderia ser definitivo para pesquisar os aspectos qualitativos relevantes do problema en questao. Diante desse inconveniente, optou-se por uma metodologia de tipo histórico-estrutural apropriada a analise das mudancas na estrutura económica e social que aconteceram no pais e mais concretamente na colónia de Yapacani, ao longo das ultimas tres decadas. Utiliza-se como fio condutor da pesquisa o plano de governo que deu origem a esta colonia.

A revisao dos antecedentes historicos, politicos, sociais e culturais que deram origem a atual realidade da colonia de Yapacani foram obtidos atraves das fontes secundarias de informaçós (censo agropecuário, censo populacional, o "plano Bohan", etc.l. No raciocinio analitico foi usada toda a informaçao disponivel, incluindo um estudo socio-económico desta colonia realizado em 1987 , no qual este autor participou.

Cabe esclarecer que por causas climaticas (excesso de chuvas na colônia Yapacani) nao foi possivel 
realizar as entrevistas inicialmente planificadas. No entanto, o estudo complementou-se com depoimentos informais de pessoas residentes nesta colônia (extensionistas, colonos dirigentes, funcionários de instituiçoes governamentais e nao-governamentais e alguns colonos), atraves dos quais se tentou resgatar informaçles necessálias para dar respostas as interrogaçues esboçadas na definiçăo do problema. Estas informaçdes foram obtidas entre os dias 1 e 15 do mes de abril de 1992 .

A complexidade do problema estudado tornou imperativo um esforço para entender a globalidade. do problema em questao, evitando tanto quanto possivel cair em abstraçôes. Do contrário, isto e, se a analise ficasse limitada a parcialidade do problema so se poderia chegar a conclusoes tambem parciais. Se bem que en alguns tipos de problemas uma resposta parcial pode ser suficiente, no caso abordado, uma análise parcial pode ser até contraproducente. Assim demonstra o fato de que as multiplas soluçes praticadas até noje, para controlar a produçao, comercio e consumo de coca e cocaina, năo só fracassaram, nesta tentativa, como estao até estimulando o problema.

\subsection{Intervençăo do Estado}

Para os fins do presente trabalio e necessário dispor de el amentos teoricos que permitam entender as decisoes tomadas pelo Estado boliviano de 1952. 
Poderemos, assim, ter elementos de juizo na hora de fazer as avaliaç̣es correspondentes. Com este propósito, tentaremos entender o significado de um "plano de gaverno" e as conseqüências derivadas de sua aplicaçăo.

\subsubsection{O Planejamento}

Certamente, a historia da economia mundial tem se caracterizado por oscilar de um extremo concorrencial a um outro extremo estatizante. Na opiniao de LANGE (1972), sendo o planejamento um meio de subordinar a açao das leis económicas em direçao a vontade humana, esta atividade foi, no passado, relacionada mais com economias socialistas do que com economias de mercado.

No entanto, no presente século, a partir da crise do sistema capitalista de 1929 e da Segunda Guerra Mundial, o Estado readquiriu importancia como ente planificador do desenvalvimento economico e social nos paises capitalistas.

De acordo com RAMOS (1983), esta tendêncla dos paises centrais nao demorou muito tempo em se manifestar, tambem, nos paises terceiro-mundistas. Ds paises desenvalvimentistas que surgiram na periferia do sistema capitalista mundial tiveram como funça principal, via de regra, a utilizaçao de todos os instrumentos da politica económica para elevar ao máximo a taxa de crescimento da renda per cápita. 
No entanto, como sera visto no presente trabalho, o crescimento econômico é uma condiçăo necessária mas nå suficiente para medir a evoluçá de uma determinada sociedade.

Um conceito de planejamento que responde a uma visao global da realidade foi apresentado por SZMRECSANYI (19.79), que entende o planejamento como "... todo um processo de intervença racional do Estado na vida sócio-economica". Desde este ponto de vista, para o citado autor, a atividade de planejamento é relativa ao tempo e espaço, isto e, ".. a natureza, os objetivos, as finalidades, os instrumentos e as funçoes do planejamento variam de acordo com o contexto sociareconómico a que se aplica. Variam principalmente com relaça ao regime politico vigente $e$ o estagio de desenvolvimento socio-economico alcançado" SZMRECSANYI (op cit, p.4-5).

Porem, e inegável que existe uma grande dificuldade na hora de explicitar os objetivos, pelo menos na fase de inicio do processo de planejamento. Esta dificuldade surge do fato de neste processo serein postos em evidencia os conflitos de intereses existentes na sociedade. - seguinte comentário sobre o caso boliviano, feito por TORANZO (1989, p.148), e uma constatacao desta dificuldade: "O peso da tradiçao de incapacidade de formulaço de um projeto nacional e de promover politicas económicas coerentes e tao grande que tanto a direita quanto a esquerda ficam prisioneiras dessa temivel acumulaça histórica". 
- Planejamento, conseqüentemente, deve ser entendido como um processo de gradativa integraçao/articulaçăo dos intereses contrapostos a presentes en uma dada sociedade.

- que até agora aconteceu, pelo menos na maioria dos paises latino-americanos, submetidos, até bem pouco tempo a regimes ditatoriais, foi a adoçao e execuça de planos elaborados e impostos de fora. Sen dúvida, este fato postergou ainda mais a surgimento de um verdadeiro processo racional de intervericao do Estado na realidade destes paises.

\subsubsection{A "Estratégia de Desenvolvimento"}

Uma estrategia estabelece a orientação fundamental do desenvolvimento ao apresentar as principais caracteristicas da sociedade que se preteride atingir no futuro. Náo so esboça a imagem-objetivo da sociedade a que se aspira, mas especifica os caminhos e meios gerais para atingir o objetivo. É obvio que, ra imagem-objetivo se expressa a ideologia das classes dominantes e, tambem, se sintetiza o carater de suas relaços coni as demais classes.

Assim, na opinizo de RAMOS (op cit, p.11), "...nao e possivel elaborar uma "estrategia" sem fazer referencia prévia aos objetivos da politica economica de um pais. Estes ultimos, por sua vez, referem-se aos resultados que o Estado espera lograr através da aplicaçao de seus 
poderes, faculdades ou capacidades no campo da produçao e da distribuiça".

A caracteristica mais importante dos objetivos se refere a sua correspondencia com um contexto sócio-histórico determinado. Q caráter historico significa que os objetivos náo tem aplicaçăo ou validez universal. Tem sua vigência circunscrita a condiçoes particulares de tempo e espaço. o caráter social expressa os interesses de fraçôs e classes sociais que constituem uma formaçao social determinada. Os objetivos tampouco sao resultado do trabalho técnico ou de recomendaçôs apresentadas por uma equipe de técnicos especializados na formulaçao de politica economica (RAMOS op cit, p.13).

A justificativa, em termos téricos, vem da ciencia oficial que os respalda. os objetivos devem sustentar-se num conjunto de conhecimentos teoricos sistemáticos que expliquem a realidade e enumciem as leis de seu funcionamento. Aqui está implicito o conteúdo ideológico, pois toda teoria e, de acordo com RAMOS (op cit, p.14) e HUNT (1989, p.22), também, ideologia.

De outro lado, deve ficar claro que os objetivos nao sao por natureza complementares ou conflitivos. Em un certo momento histórico e diante de problemas especificos, os objetivos poden parecer conflitivos; mas, noutro momento historico e diante de Froblemas distintos, tais reiaçoes podem transformar-se em complementares. Assim, por exemplo, tem sido freqüente a 
complementariedade entre os objetivos de crescimento e ocupaçao, sobretudo quardo existe un alto nivel de desemprego e subemprego; mas também existem relaçâs de conflito quando o aumento da ocupaçăo leva ao sacrificio da taxa de crescimento e vice-versa.

E importante tambem salientar o fato de que "... a formulaçao dos objetivos sofre a influencia das deficiencias teoricas na interpretaçao da realidade, e a limitaçăo dos recursos que muitas vezes obriga a priorizar uns objetivos em lugar de outros". (RAMOS op cit, p.22).

\subsubsection{0 planejamento como processo de intervençao}

raciona 1

De acordo com a concepgào de planejamento adotada no presente trabalno, elimportante destacar o fato de que no processo de intervençăo do Estado na socjedade riăo e a elaboraçăo de planos e programas de desenvalvimento o elemento mais importante, mas sim a contiruidade do proprio processo de intervença do Estado. Nao e a certeza e a correta elaboraçao dos planos o que garante o sucesso da intervença do Estado, mas sim os reajustes e a circularidade do processo, onde as tentativas sejam permanentemente avaliadas e reformuladas.

No esquema de planejamento elaborado por SZMRECSANYI (op cit, p.14), săo definidos cinco estágios ou fases interdependentes que mostram a importancia da 
circularidade e o dinamismo do processo de planejamento (ver grafico 1). Estas fases sao descritas do seguinte modo:

"a) diagnóstico da evoluçao do complexo socio-econamico (sistema, setor ou regiao) que se pretende influenciar, isto é, modificar ou consolidar através do planejamento;

b) formulaçao de uma politica de desenvolvimento para o complexo;

c) elaboraçao do plano propriamente dito;

d) execuçæo do plano;

e) avaliaçao periodica dos resultados obtidos; e

f) progressiva reformulaçao do diagnostico, da politica de desenvalvimento, dos objetivos e dos instrumentos do plano"(SZMRECSANYI op cit, p.12). 
GRÅF ICO NQ 1

esquema básico de plamejamento

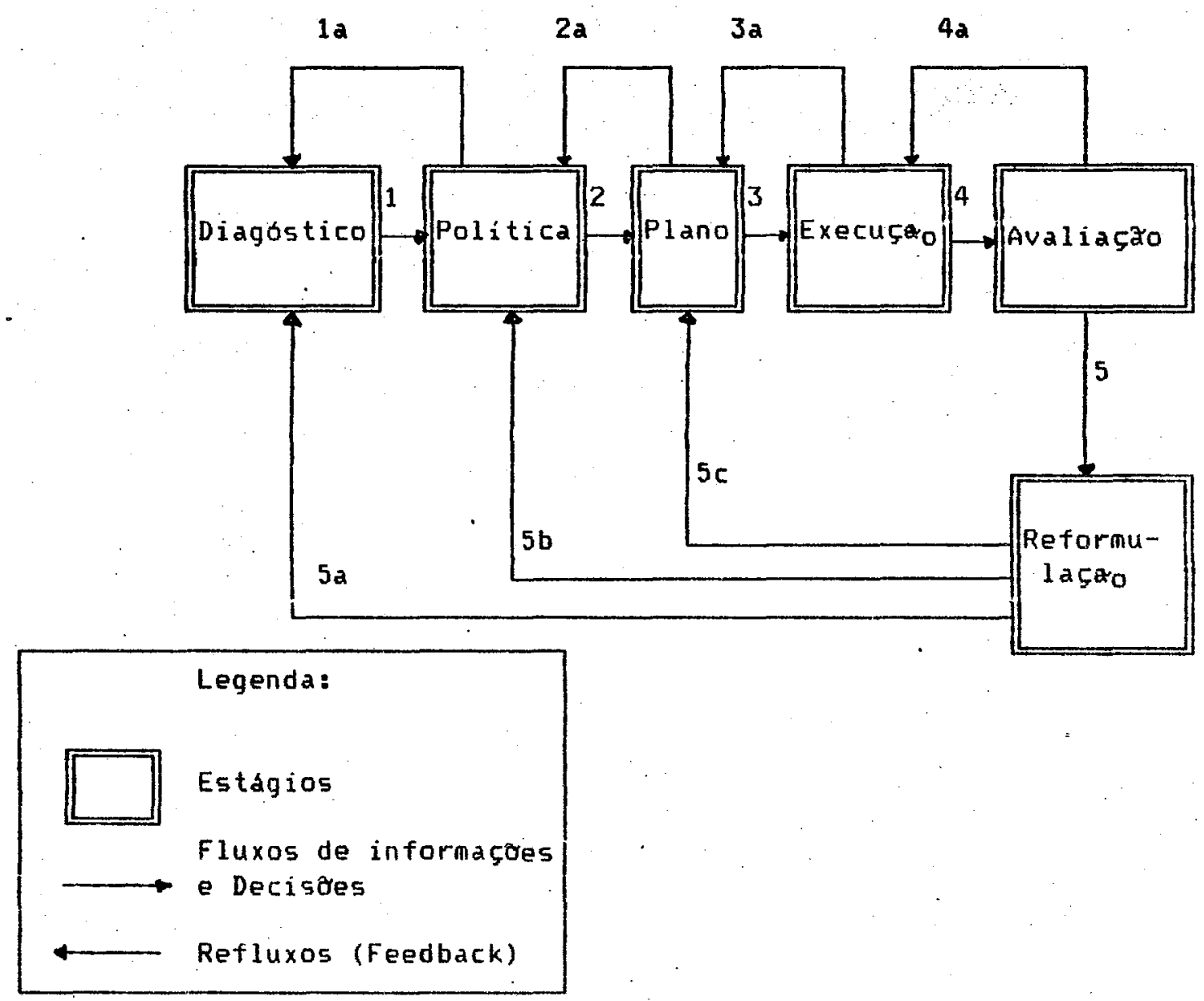

Fonte: SZMRECSANYI 1979: 14

De acordo com este esquema, fica evidente a importancia do dinamismo que deve ter o processo de planejamento. o esquema salienta o carater circular do processo onde a retro-alimentaço de cada uma das fases coristitui uma constante ao longo do processo. 0 resultado deste modo de encarar o. desenvolvimento de un pais veve ser, no longo prazo, a institucionalizacao de um processo 
iterativo de planejamento, onde as diferentes fases do processo estejam em permanente interdependencia e permitindo niveis cada vez maiores de articulaça dos intereses dos diferentes grupos da sociedade.

o ponto de partida do processo de planejamento e o diagnóstico. Só e possivel tratar um paciente após conhecer a sua situaçao inicial. Neste ponto é importante destacar que a omissao de alguma parte do sujeito, decorrente de uma visao parcial e excludente, pode trazer graves conseqüencias nas fases posteriores do processo de planejamento.

o passo seguinte, uma vez realizado o diagnóstico, formular uma politica de desenvolvimento para - complexo socio-económico, cuja evolucăo futura se pretende planejar.

De acordo com o citado autor, "... a elaboraça do plano propriamente dito tem inicio com a escolha de seus objetivos e instrumentos. Confrontando as conclusdes do diagnostico com os principios definidos na politica de desenvolvimento econamico e social, chega-se a uma lista de objetivos para a evoluça futura do complexo (sistema, setor ou regizo) que se pretende submeter ao planejamento. Esses objetivos costumam ser simultaneamente quantitativos e qualitativos (...). Uma vez selecionados os objetivos, cabe escolher os instrumentos mais adequados a sua realizaçao. Essa escoltha requer. um grande discernimento, 
na apenas das metas alcançáveis no horizonte do plano, como dos fatores econômicos, sociais e politicos que estao em jogo. Ná há planejamento socio-econamico que beneficie a todos indistintamente. Cada objetivo e cada instrumento do plano sempre envolvem un juizo de valor" (SZMRECSANYI op cit, P.15-6).

Finalmente, e importante no presente trabalio prestar atençăo nas sequintes colocaçöes deste mesmo autor: "A viabilidade de um plano so e efetivamente testada atraves de sua execuçao (...). A continuidade do planejamento também é interrompida quando nao ha uma avaliaça dos resultados da execucazo dos planos e programas. E dessa avaliaçao que fluem os reajustes necessários a boa execuça do plano através do tempo. Dela resulta tambem, a mais. longo prazo, a reformulaça do diagnóstico inicial, da politica de desenvolvimento, e do proprio plano. Uma reformulaça levada as ultimas consequencias acaba conduzindo a elaboraçao de um novo plano (...). "(ZSMRECSANYI op cit, p.17-9. us gritos. sao de F.O.H.B.). 


\section{A CULTURA DA COCA}

Certamente a realidade nao é o que é, mas o que as pessoas acreditam que ela seja. As vezes este fato pode perpetuar um erro; pois, como disse o sociologo norteamericano W.I. Thomas (citado por DEL OLMO, 1991, p.31-2): "se os homens definem uma situaçao como real, entao ela será real pelas suas conseqüencias". Com relaçao a cultura da coca, a opiniăo pública internacional tem uma informaçăo distorcida da realidade. No entanto, e com base nessa informaça que tem-se formado um juizo sobre o problema da coca e seus derivados.

$$
\text { Em vista disso, este capitulo visa esclarecer }
$$

- leitor nao familiarizado com a cultura andina le talvez influenciado pelo discurso oficial e pelas informaçes geralmente tendenciosas da imprensa oral e escrital, sobre alguns aspectos historicos, politicos, culturais, sociais e económicos a respeito da cultura da coca e que sao importantes para a compreensao do presente trabalho. 


\title{
2.1. Antecedentes da cultura da coca na Bolivia
}

\begin{abstract}
Estima-se que a cultura da coca vem sendo conduzida pelos nativos da regiag andina nos últimos cinco milenios, ou seja, desde a epoca pre-incaica. A folha de coca é tradicionalmente usada de múltiplas maneiras pelos camponeses de quase todo o territorio boliviano. No entanto, vale a pena esclarecer que o consumo da foltha de coca nao tem nada a ver com a imagem existente, atualmente, no ambito da opiniao pública internacional $1 \%$.
\end{abstract}

Em um importante estudo antropologico, sobre - Uso tradicional da foliha de coca na Bolivia, CARTER e MAMANI (1986, p.17) apontam o seguinte: "A utilizaçao mais comum da folha de coca e para a mastigaço, embora seja, também, utilizada como medicamento, energético e como integrador social nas comunidades tradicionais. E tambem. utilizada como cataplasma, en infusao, como meio de adivinhaçă do futuro, de fazer diagnósticos de doenças, de aplacar a ira dos maus espiritos, sendo definitivamente um auxiliar no confronto com o mundo incerto e ameaçante".

0 Mabito do "aculli"l dos habitantes andinos tem despertado, desde os primeiros tempos da

10 A opinia pública internacional trequentemente confunde coca com cocaina, ou "cocaismo" (consumo de coca) com "cocainismo". (consumo de cocaina). Isto equivale a confundir o vinho com a uva. o qual e um grande erro, contribuindo para justificar uma intervenço externa na sociedade boliviana.

11 Palavra quechua que denomina a pratica da mastigaço da folina da coca. Do ponto de vista quimico, o "aculli" é um processo complexo onde intervém, além da cocaina, pelo menos outros 13 alcaloides, vitaminas, minerais e bleos essenciais. Ha opinizo de CAHELAS e CANELAS (1983, p.84-85), ainda sxo desconhecidos os efeitos que pode ter esta combinaçăo de elementos; isso sem levar en conta a açzo da saliva, os diferentes sucos gastricos a reativo alcalino (cinza de certos cactus) com que é mastigada e consumida a folha da coca. 
Conquista da America ate os tempos atuais, uma inesgotavel controversia entre cientistas de diferentes áreas, na qual podem ser observados elementos de alto conteúdo ideologico. A origem deste debate acha-se na afirmaça de que a folha de coca tira a fome dos mastigadores.

De un lado temos a teoria dos efeitos nocivos da coca na alimentaçao, apresentada principalmente por GUTIERREZ. Segundo este autor (1944, p.5), "o mastigador da coca a consome para anular a desagradável sensaçao que produz a inaniçæo crônica. Mas a consumo da droga1a ocasiona, depois de alguns anos, a perda do apetite". mastigador viciado, afirma ele, prefere a droga a comida, estabelecendo-se assim um circulo vicioso: começa a mastigar coca para suprimir a fome, provocando a perda do apetite, e se acaba comendo ainda menos, por causa do consumo da coca.

De outro lado, temos autores, como BUCHARD (1983), que sustentam que os componentes nutricionais da coca poderiam ser muito significativos quer como complemento da dieta, durante periodos de escassea aguda ou crónica de alimentos, quer pela vital importancia no tratamento favoravel de possiveis problemas permanentes e generalizados do metabolismo dos nitratos de carbono, entre os camponeses dos Andes. Segundo esta otica, a coca nem ocasiona perda do

1 - Note-se que é utilizado o termo "droga" como sinónimo de foltha de coca, o qual, segundo especialistas na materia como BURCHARD (1983, p.165) e MAYER (1983, p.226), es farmacologicamente incorreto. Foi o estatuto legal internacional, no qual se enquadra a coca, que deformou os efeitos fisicos e psiquicos objetivos da folha de coca. 
apetite nem reduz a ingestao de comida. Os ingredientes da folha de coca teriam uma importancia crucial nos problemas de hipoglicemia que estao presentes na populaçao camponesa dos Andes. Assim mesmo, o alto conteúdo de calcio, tanto na folha quanto na cinza utilizada na mastigaço da coca, pode ser de vital importancia no tratamento da intolerancia a lactose que é muito freqüente nos povos andinos.

Observa-se que o crescimento da produçao de coca coincidiu com o auge da mineraça, que seguiu o descobrimento dos ricos filoes de prata de Potosi, no ano de 1545. A exploraça mineral requeria o concurso de um segmento importante da populaçao nativa, e os espanhois perceberam a necessidade da coca como ingrediente indispensável para mobilizar a mao-de-obra, convencidos de que os nativos nao realizariam nenhum tipo de trabal ho sem o uso da folha de coca. A coincidencia do "boom" da mineraça e da produça da coca, no passado, sugere a existencia de uma relação entre ambas as produçees (CARTER e MAMANI, op cit, $P .72)$.

Com o decorrer dos séculas, segundo FERNANDEZ (1932), a coca continuou desempentiando um papel primordial na indústria da mineraçao. Os centros de mineraçao destacaram-se sempre como os maiores consumidores de coca do pais. Tal foi a quantidade consumida pelos trabalhadores das nitinas que, como conseqüência da virtual paralisaçao destes centros de produçao, durante a grande depressao muridial, a 
demanda de coca se reduziu consideravelmente. Chegou ao ponto de provocar uma aguda crise economica nos Departamentos produtores de la Paz e de Cochabamba. De acordo com BALCAZAR (1956), isto motivou o governo da Bolivia, mediante o decreto de 4 de agosto de 1940, a declarar a coca artigo de primeira necessidade, ordenando sua venda obrigatória en todas as empresas mineiras e ferroviárias.

Uma outra funçao da coca muito citada quando se fala da populaçao indigena, e a relacionada com as viagens pelos acidentados caminhos andinos. Segundo MORTIMER (1974), desde muito tempo atrás, perdura o costume dos viajantes en deixar o "bolao da coca" mastigada em pequenos montoes de pedras que se encontram nos caminhos estreitos dos Andes, como oferenda ao espirito que cuida do lugar.

Tamben se sabe que, dada a caracteristica de fácil negociaçao da coca, foi utilizada entre os indigenas como um meio de pagamento.

E interessante salientar que grande parte dos costumes descritos acima ainda permanecem vigentes apesar jo passar do tempo. Para uma boa parte da populaça indigena boliviana praticamente nao existe nentum ato da vida domestica, social ou religiosa no qual a cora esteja ausente.

\subsection{Breve história da cocaina}

Segundo CANELAS e CANELAS (1983, p.326)," "o principio ativo da cocaina foi isolado por Federico Gaedile, en 1855, que o chamou de eritroxilina. Mas, o exito final e atribuido a Alberto Niemann, da Universidade de Gottingen 
(Alemanha), que a caracterizou quimicamente e a chamou de cocaina. Posteriormente, o neurologista italiano Paolo Mantegazza fez uma contribuiçao muito importante a psicofarmacologia da cocaina". Estes e outros autores como ARNT (1991), concordam ao afirmar que a monografia de Mantegazza influenciou um grande número de pesquisadores, incluindo Sigmund Freud.

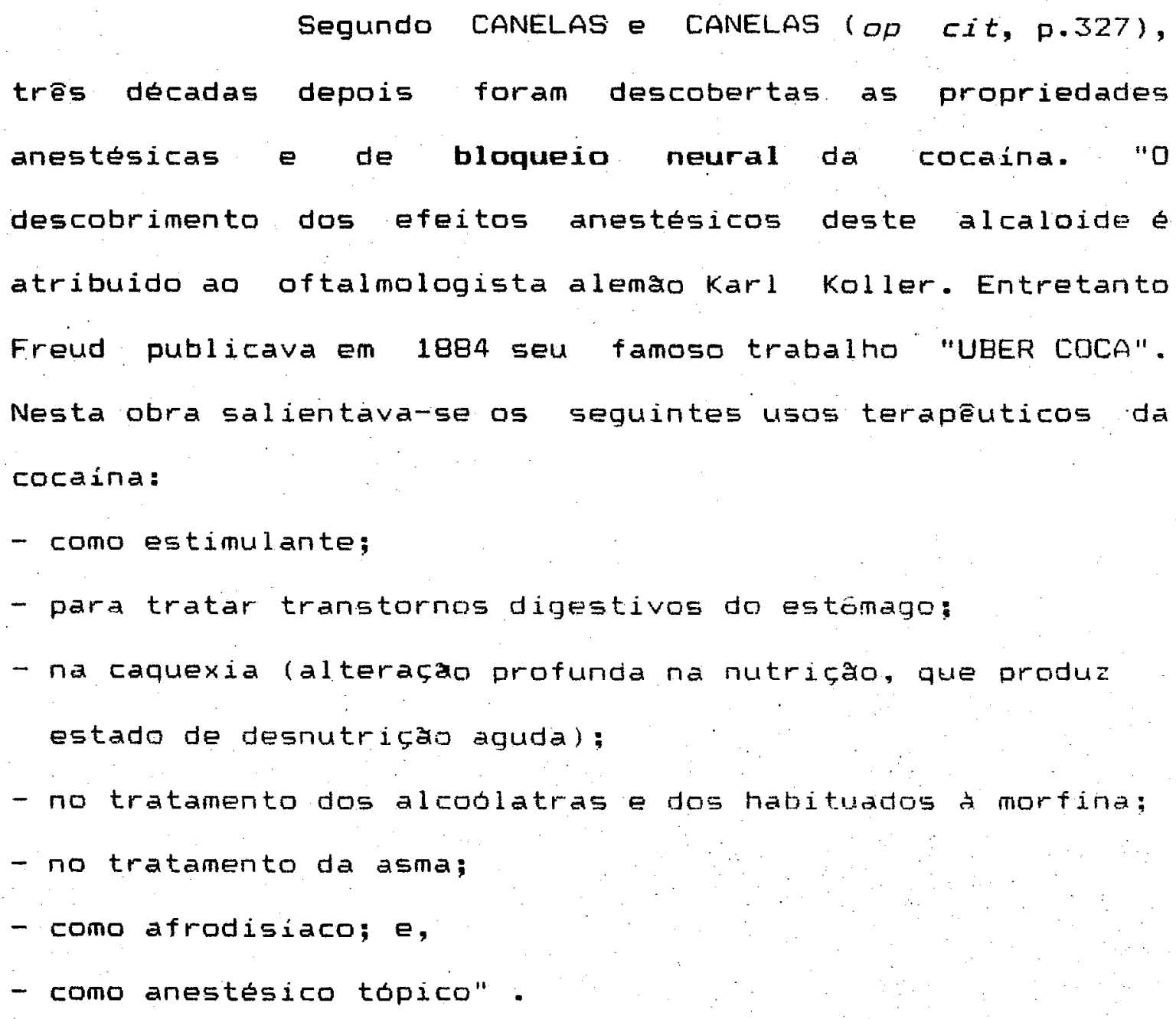

Ainda estes autores sustentam que tanto Freud quanto outros medicos e pesquisadores nao limitavam o uso farmacológico da cocaina a sua recontiecida eficiencia como 
anestésico tópico e para o bloqueio neural na cirurgia, mas tambem acreditavam que a eocaina era util na cura de uma variedade de doenças. Ela parecia ter uma aparente base objetiva porque, devido a sua condiçao de estimulante, fazia desaparecer os sintomas de muitas das citadas doenças, ainda que naturalmente sem cura-las (CANELAS a CANELAS, op cit).

Como resultado da extensao do uso farmacológico da cocaina veio a abuso e a dependencia patológica. Em 1891, segundo ARNT (1971) e CANELAS e CANELAS (1983), haviam aparecido perto de 200 informes de intoxicaçao sistemática com cocaina, incluindo 13 mortes. Inclusive um dos pacientes de freud morreu por causa de uma dose excessiva que ele mesmo receitou.

Foi assim que chegou, no final do século, a primeira "epoca de ouro" do uso macico da cocaina, tanto na Europa quanto nos EUA. Apareceram remédios patenteados, tônicos e bebidas nao-alcodicas. Segundo os autores citados, "... muitos cientistas de grande reputaca alardeavam as qualidades das folhas de coca e da cocaina é, junto a eles, alguns novelistas e dramaturgos usaram a cocaina como elemento de suas tramas. Sobre este fertil terreno veio a chamada livre empresa, aproveitando a virtual iṇexistencia de regulamentos legais sobre a produçao e venda de remedios e bebidas refrigerantes que continham substâncias estimulantes" (CANELAS e CANELAS op cit, p.329). Na Europa, un quimico da córcega, chamado Angelo Mariani, pode ser considerado como a personificaçao 
do sucesso comercial desta primeira fase de popularidade das folhas de coca e da cocaina. Segundo ARNT (op cit), foi o primeiro importador de folhas de coca, com as quais fabricou um vinho que batizou com o seu nome e que adquiriu rapida fama, chegando a se constituir na bebida predileta de muitos personagens importantes da época, tais como o Papa Leao XIII - Júlio Verne e Tomas A. Edison.

Ainda que o exito de este vinho tivesse sido indiscutivel, foi a Coca -Cola, introduzida pela primeira vez no mercado norte-americano em 1886, que atingiu uma maior fama internacional. Este produto perdura ate hoje como simbolo da presenca norte-americana em praticamente todo o planeta. De acordo com CANELAS e CANELAS (op cit, p.331), citando PHILLIPS e WYNNE (1980)1." "seu criador foi um quimico de Atlanta, John Styth Pemberton. a xarope originalmente continha cocaina, cafeina e extratos de nozkola, e agua gasosa ou outra agua carbonatada. Neste primeiro estagio, a Coca-Cola foi promovida como um tónica. para todas as afecços nervosas -neuralgia, nisterij, melancolia, etc. Dois amos depois, seu novo proprietario, 0. Chandler, suprimiu todas as referencias a suas supostas virtudes medicinais e a promoveu simplesmente como uma "bebida refrigerante e excitante". Nao obstante, continuou contendo cocaina até 1903, ano em que esta foi substituida

$1:$ PHILLIPS, J. and WYNNE, R. Cocaine: the mystique and the reality. Hew York, 1980 . 
por um tempero "descocainizado" das folhas de coca, fato este sujeito ao controle federal até $1969 "$.

Contudo, apontam ainda estes autores, quase com a mesma rapidez se passou de un extremo para outro. A cocaina depois de ser considerada a panacéia universal passou a ser considerada como a pior praga conhecida pela humanidade. Uma das causas para esta mudanga tao radical foi a justificada reaçao médica e popular aos excessos da epoca dos medicamentos patenteados.

A publicidade desfavorável com respeito ao consumo da cocaina e a legislaçao especifica que punha fora da lei seu consumidor, distanciaram-na do âmbito da respeitabilidade entre 1920 e 1960 . Este prolongado periodo de tempo, associado ao seu elevado custo e a disponibilidade de anfetaminas, a partir de 1930, determinou que o consumo nao-médico da cocaina ficasse restrito a alguns setores: aos grupos snobs da alta sociedade, aos elementos opulentos do sub-mundo do tráfico de outras drogas ilicitase, principalmente, aos músicos, as estrelas do cinema e alquns escritores, ou seja, uma minoria ànda que muito visivel (CANELAS E CANELAS oP cit).

Mas, a partir de 1960,0 consumo ilicito da cocaina mos EUA tem voltado a usufruir de um inesperado e acumulativo ressurgimento. Este pais tornou-ie o mercado mais importante para os narcotraficantes, ainda que o tráfico ilicito deste estimulante tambem abranja outros paises industrializados. 
No que diz respeito as causas do

reaparecimento súbito da cocaina nos EUA, os autores de

"Cocaine: the mystique and the reality" citados por CANELAS

e CANELAS (op cit, p.336), enumeram:

- "como pano de fundo deve ser considerada a nova posiça

- econámica dos EUA. No contexto internacional, o pais converteu-se na primeira potencia mundial. Sem esta opulência, parece obvio que o "cocainismo" nao teria alcançado tanto sucesiso. Neste pais o preço de uma grama de cocaina chegou a ser até cinco vezes maior do que o de uma grama de ouro.

- A Guerra do vietna, que converteu en heroinómanos um número indeterminado de soldados norte-americanos. Estes tiveram acesso a heroina nos prostibulos de Saigon e outras cidades vietnamitas a um custo infimo. No retorno, provavelmente se converteram em adeptos da cocaina pelo sentimento de euforia que conseguian com este produto.

- A repressao policial, obviamente necessaria, contra o tráfico ilicito de anfetamina que havia atingido extremos alarmantes e, convém destacar, sao estimulantes que têm os mesmos, efeitos euforicos da cocaina ainda que com uma toxicidade bem maio:- Dai, a facilidade com que os adeptos da anfetamina optaram pela cocaina.

- A simultanea conjuntura da oferta oportuna e sustentada pela maciça emigraça cubana anticastrista de 1960. Muitos deles integravam os diversos niveis da máfia cubana e 
levaram, aos EUA, o hábito do uso da cocaina, a sua pericia no tráfico e suas conexoes sul-americanas".

Para concluir, e interessante 0 seguinte comentário de JORDAN (1990) sobre a cocaina: "em milhares de anos a coca nao mudou os aspectos sdcio-culturais do mundo andino, adaptados a uma economia de pobreza social devido a baixa potencialidade agricola do solo. Mas a cocaina em menos de duas décadas conseguiu mudar parâmetros de renda, riqueza, qualidade de vida, conduta familiar e social, acesso ao crescimento, mesmo nas sociedades mais tradicionais" (JORDAN op cit, p.11).

\subsection{Debate e controle da coca}

A folina de coca tem sido objeto de um prolongado debate que se iniciou,pouco depois da conquista espantiola no século XVI, isto e, antes do descobrimento da cocaina. Este debate tem-se intensificado durante certos periodos com a concurso de movimentos proibicionistas. No entanto, em outras epocas era praticamente esquecido o problema.

Segundo GAGLIANO (1963), a primeira cruzara proibicionista teve inicio como resultado do grande debate, no seculo XVI, que relacionava a coca com a religiao nativa. Esta associaçă converteu a coca en objeto de ataques por parte de alguns membros do clero espanhol. Estes consideravam a coca como um "agente do diabo" e que dificultava a conversao dos indios ao eristianismo. 
Recomendava-se, entao, a destruiçăo de todas as plantaçoes de coca e a proibiço de seu consumo. Nem todo o clero adotou uma posiçao tåo extrema; pelo contrário, alguns já pensavam que a coca era uma fonte eficaz de nutriça e energia para os trabalhadores indigenas. Contudo, o Conselho Eclesiástico de Lima, em 1552, condenou o consumo de coca nos rituais religiosos, solicitando a coroa $e$ aos funcionarios coloniais a proibiçao de seu cultivo e consumo. A oposiço clerical ao consumo de folha de coca levantou uma forte reaçao entre os cultivadores desse produto, os quais organizaram um "grupo de pressao" que se colocou en defesa da folha de coca. Este grupo respondia as acusaços proibicionistas, que consideravam o consumo de coca uma mera superstiçao, insistinda nos beneficios para o indio e que Deus havia proporcionado a planta para consumo dos nativos. Sem dúvida, como apontam CARTER e MAMANI (1986), o argumento mais persuasivo, empregado pelos defensores da folha de coca, era de indole economica. Afirmavam que a coca era absolutamente essencial para que os indios realizassem qualquer tipo de trabalho, seja ra mineraça ou na agricultura, e que sem ela, a economia peruana paralisaria e o dano teria sido grande para a Coroa espantola.

Dado que, na opiniao dos citados autores, o sistema colonial espanhol estava mais interessado em conseguir beneficios do que a "salvaçao de almas", os ataques contra a coca se apaziguaram. Na metade do seculo 
XVII, a primeira cruzada contra a coca terminou em derrota. Contudo, o fracasso da primeira batalina proibicionista no Peru, nao significou o fim da guerra. Ainda que a maioria dos espantídis tenha se convencido da inutilidade de combater - habito do consumo de coca entre os indios, permaneciam os que deploravam tal prática e continuavam atacando-a esporadicamente.

Segundo os mesmos autores, "o primeiro seculo de independencia constituiu um periodo en que a coca teve muito pouca oposiça na Bolivia. Um estudo da legislaçao boliviana do século XIX năo revela nenhum intento de restringir ou controlar a coca, afora aquele relacionado aos impostos. No entanto, isto nao significa a ausencia de criticas contra a indústria da coca" CARTER e MAMANI (OD cit, p.133).

E importante destacar que neste periodo tal indústria estava nas maos da Sociedade de Proprietários de Yungas (SPY)14, que era constituida por pessoas de grande influencia politica no pais. Uma vez que estavam en jogo seus intereses econámicos e de poder, eles utilizaram

14 A SPY, criada en 1830, era uma associaçăo de fazendeiros da Provincia dos Yungas de La Paz que praticamente tinham o monopólio da produção da coca na Bolivia até a Reforma Agrária de 1953. Segundo CARTER e MAMANI (op cit, p.93), os fazendeiros dos yungas nao só doninavam a Provincia, mas tambem exerciam uma considerável influencia na politica dos Departamentos e inclusive da naçzo. Alguns deles, como Andrés Santa Cruz, José Ballivián e José Luis rejada Sorzano, chegaram a ser presidentes da Bolivia. 
habilmente diversos argumentos relacionados com o caráter. cultural e o proprio valor nutritivo da folha de coca.

Entretanto, os intentos de erradicar ou reduzir drasticamente o cultivo e consumo da coca surgiram novamente no século $x x$, como resultado de presseses internacionais. De acordo com NACIONES UNIDAS (1950, p.40) "Na Conferência Internacional do Ópio, celebrada en Genebra entre novembro de 1924 a fevereiro de 1925, a delegaça boliviana defendeu a produçă de coca, mas no fim, assinou um protocolo que a classificava como droga nociva".

Segundo SPY (1928), este tipo de pressao motivou a SPY a empreender uma prolongada campanta na defesa da coca. A SPY justificava que a cocaina nao constituia um problema na Bolivia, pois, a produça total de coca era consumida na forma tradicional. Negando que a coca fosse uma droga, a SPY salientava o fato de que a quantidade de cocaina ingerida por um indigena ao longo de um ano era tåo reduzida que nå significava problema algum para as defesas do organismo. Além do mais, defendiam.o valor da coca como nutriente baseados numa análise quimica feito por um laboratório americano a pedido da embaixada boliviana, em Washington. A análise revelava que a folha de coca continta vitaminas $A, B 1, B 2, C E$, niacina e outros compostos importantes (yer maiores detalines sobre coca e nutriça no apendica II, p.151). A SPY argüia que a coca era responsavel pera boa saude dos trabalhadores da mineraça e camponeses bolivianos, apesar de sua deficiente alimentaça, clima 
hostil e falta de higiene. Por ultimo, a SPY alertou o governo para que adotasse uma posiçao mais firme diante das pressoles exercidas por organizaçøes internacionais, e defendeu a necessidade de um estudo cientifico da folha de coca que permitisse esclarecer o preconceito que prevalecia en tais instituçoes.

Na opiniăo de QUIROGA (1990), é possivel que as pressôes da SPY tenham contribuido para que o governo boliviano nao ratificasse o protocolo da Segunda Conferencia do Opio (1927). Ficou acertado que o governo nao se comprometeria a restringir a cultura da coca no pais nem proibiria seu consumo entre a populaçao indigena. Nao obstante, en 1936, os governos do Peru é da Bolivia assinaram um acordo para formular uma legislaço social destinada aos indigenas e encontrar meios para a erradicaçao do alcoolismo e o "consumo descontrolado da coca". Assim mesmo, na primeira lei anti-droga da Bolivia (1939), a lista de drogas proibidas incluia a cocaina e a ecgoninax=, mas nao menciona a folha de coca.

15 De acordo com BLRCHARD (1978), "a ecgonina é o produto terminal co processso de hidrolise e de metabolismo resultante da mastigaça da folita da coca misturada com substancias alcalinas (cal, cinza, etc.). Assim,..., devido a este fenómeno a quantidade de cocaina que ingere o mastigador de coca e insignificante se comparada com a quantidade de ecgonina. Um estudo mais recente,..., ten mostrado que a ecgonina e 80 vezes menos tóxica do que a cocaina. Hlém disso, ele demonstra que a aça euforica e anestésica da molécula de cocaina so pode produzir-se quarido ela está intacta" (BURCHARD 1978, $p: 164-65$ ). Com base nestes argumentos farmacologicos, pode-se concluir que existe uma grande diferência entre "cocaismo" e "cocainismo". 
Mas, de acordo com MENDOZA (1941), a oposiç\%o a coca na Bolivia era cada vez maior. En 1940 o primeiro Congresso. Médico Nacional, reunido na cidade de La Paz, declarou sua aversao a produçá e consumo da foltha da coca. No ano seguinte, a quarta Conferência Panamericana da Cruz Vermelha, reunida em Santiago de Chile, instou o governo boliviano e a Cruz Vermelha a diminuirem gradativamente o consumo da coca entre os indigenas. Os ataques se basearam, fundamentalmente, nos supostos efeitos nocivos derivados da ingestao crónica de cocaina, resultante da mastigaça habitual da coca. Argumento que, como foi visto acima, eum claro equivoco (cf. notas de rodape no 12 e 15 ).

Diante da oposiçăo tanto interna como externa, a SPY continuou seus esforços na defesa da indústria da coca. Em 1948, segundo SPY (1948), esta organizaça solicitou ao governo que apresentasse um estudo completo sobre a coca nas Naçbes Unidas, e que a delegaça boliviana propusesse a exclusac da folla de coca da lista de drogas proscritas preparada pela Segunda Conferencia de óplo de 1927 .

A resposta do governo, de acordo com CARTER e MAMANI (1986), foi pedir a inclusao da Bolivia no estudo das Naçoes Unidas sobre os efeitos do consumo da coca que a ONU havia aceitado conduzir jor solicitaça peruana. A comisszo de estudo da onU passou tres meses, em fins de 1949, no Peru e na Bolivia pesquisando os efeitos do consumo 
da coca e as possibilidades de limitar sua producaro controlar sua distribuiça. Qs integrantes da comissao mantiveram conversaçoes oficiais de toda indole, mas escasso contato com os consumidores. Com estas abservaços superficiais, chegaram a conclusao de que a coca era daninha pela relaça direta que tinham seus efeitos com as da cocaina, mesmo que a mastigaçăo da folha năo levasse a dependencia no "sentido medico" da palavra. Os efeitos negativos da coca foram definidos como: (1) inibiça da sensaçao de fome, (2) induçăo de mudanças năo desejadas de carater intelectual e moral; $e$ (3) reduça do rendimento econámico do trabalino produtivo, mantendo desta maneira o baixo nível econômico de vida. A recomendaçăo da comissao, como soluçao para o problema, foi melhorar as condiçoes de vida da populaçăo consumidora e simultaneamente iniciar um programa governamental para a supressăo do cultivo e consumo da coca.

Na opiniao de QUIRogA, com a dissoluço da SPY, depois da Reforma Agraria de 1953, o governa boliviano se propos a controlar a produça da coca de acordo com a Convençao de 1925, teoricamente 1 imitando novas plantaçoes e fomentando o cultivo de frutas e de cafe. Aparentemente nao se tratou de um intento muito serio, pois continuaram as pressaes internacionais. Em 1961 a convençao Única das Nagoes Unidas sobre Drogas e Narcoticos incluiu a coca na lista de drogas proscritas, submetendo-a a controle "obrigatorio" mais rigoroso. Pela primeiravez, as partes interessadas se viram obrigadas a tomar medidas que 
restringissem e controlassem o cultivo da coca, e assumiram a obrigaçao de abolir o hábito da sua mastigaça num prazo de 25 anos.

No entanto, de acordo ainda com CARTER $E$ MAMANI (op cit), en 1964, o Grupo Consultivo Inter-americano sobre a Problema da Folha de Coca, reunido em Lima e patrocinado pela oNU, recomendou com "urgencia" a substituiçao da coca por outras culturas a a proibiçao do pagamento de haveres na forma de "drogas nocivas" (cf. nota de rodape $n .9$, cap.11. Ao mesmo tempo instou a todos os paises a ratificarem a Convença única de 1961 e a criarem comissoes nacionais para o controle de narcoticos. A Bolivia foi censurada pela sua negligência medianté uma resoluçao apresentada pelo Brasil, e apoiada pela Argentina, Chile, Colambia e Equador. Tal resoluçăo solicitava ao governo boliviano a multiplicaçăo dos seus esforços no sentido de abolir o hábito da coca, na mesma linha de medidas impostas ao Peru.

Como foi visto, as pressoes internacionais aumentaram durante a. década de 1970 como consequencia do incremento do consumo de cocaina nos Estados Unidos e na Europa. Dai que, em 1973, a governo novamente decretou a erradicaço paulatina da coca e criou a Direcăo Nacional para o Controle de Substäncias Perigosas (DNCSP). Esta instituicao assumiu a responsabilidade do combate a produçao, ao cultivo, a distribuiçă e a venda destas drogas. En resposta às pressaes dos EUA, o governo boliviano 
adotou a politica de controlar o tráfico ilegal de cocaina e começou a examinar a possibilidade de substituiçao da coca por culturas alternativas. Em dezembro de 1974, de acordo com WHITAKER e VILLEGAS (1976), foi aprovado um projeto de 8 milhoes de dólares, cujo objetivo era determinar a viabilidade de um programa de longo prazo que controlasse e reduzisse a produça da coca no pais. Este projeto piloto, iniciado en 1975, levou a posteriores acordos bilaterais firmadas em 1977, 1978 e 1979. Nesses acordas, os EUA proporcionavam uma importante ajuda financeira a DNCSP na luta contra a comércio da droga, incluindo 11 milhoes de dolares para projetos de desenvolvimento agricola na regiao dos Yungas de La Paz e na regizo do Chapare de Cochabamba.

Contudo, as fortes pressoes domesticas e internacionais, pela falta de consideraça para com os consumidores tradicionais e as implicaçoes sociais desta nova campanha contra a coca, forçaram uma revisao do objetivo a longo prazo que propunha a total erradicaça da cultura no pais.

Segundo CARTER e MAMANI (op cit, p.138-9), "em 1976 foi reatualizada a lei de narcoticos de 1973 . a novo decreto declarava que se racionalizaria, isto e, que se controlaria de tal maneira a produço da coca que o destino fosse so o mercado legal, a demanda interna, sem excedentes para a produça de cocaina. Esta meta seria atingida seguindo o programa de substituiçăo de cultivos. Como primeiro passo, todos os produtores da coca tinham a 
obrigaçao de registrar seus plantios na DNCSP ou arriscar-se a que fossem destruidos. Os plantios nao. registrados poderiam sofrer intervençă e serem expropriados pelo governo".

Posteriormente, em 1978, de acordo com QUIROGA ( $\left.a_{p} c i t\right)$, a governo ordenou o registro e a expediço de licença pela DNCSP, a todas as pessoas envolvidas na venda da coca. Declarou ilegal o transporte de qualquer quantidade da coca dentro do pais sem a correspondente foltia de tránsito outorgada pela DNCSP. O decreto provocou um energico protesto do Oitavo Congresso Nacional de Medicina Natural y Cultural Aymara e Inca celebrado no Tiawanaku.

Apesar dos protestos, o projeto continuou seu curso. En fins de. 1980 se completou a fase de pesquisa e estava tudo preparado para levar a cabo "um projeto em todos os niveis de diversificaçă agricola na regiăo do chapare" que tinha sido elaborado no ano anterior pela Agencia Americana para o Desenvalvimento Internacional (AID) (CARTER e MAMANI op cit, p.139). No entanto, todo o programa de atividades foi suspenso a partir do "golpe de estado" protagonizado pela junta militar que, segundo a opiniao geral, esteve diretamente relacionada com os mais importantes traficantes de cocaina da Bolivia.

Pressoes internas, unidas a dependencia do pais da assistencia econamica e militar dos Estados Unidos, apontam CARTER a MAMANI (1986), convergiram para o "golpe de 
estado" en agosto de 1981 que se supunha havia expulsado do governo os agentes dos traficantes de cocaina. a novo regime revelou intençoes de renovar a luta contra a coca e a cocaina. Em principios de 1982, uma nova lei de narcoticos decretou o estabelecimento do monopolio estatal para a compra e venda da coca. Tambem fez concentrar a produçao nos Departamentos de La Paz e Cochabamba, converterido em ilicitas as plantaçoes da coca nos outros departamentos.

Vale a pena salientar que esta lei teve que ser modificada antes de ser posta em vigor definitivamente. Ela foi decretada diante da grande ameaça que se começava a vislumbrar no caso da expansao da cultura da coca, nas regioes nao tradicionais do pais. Este foi justamente o caso da colonia de Yapacani no Departamento de Santa Cruz e algumas outras de menor importancia.

De acordo com a narraçao feita, o debate em torno da coca e a nutriçăo vem de longe, resultando incompreensivel que ainda permaneca sem resoluçăo. A maioria dos raciocinios, respondem, no melhor dos rasos, a uma interpretaça simplista e excludente da realidade. Ignora-se toda uma gama de fatores socio-culturais, economicos e inclusive fisiológicas.

Os autores de "Bolivia: coca cocaina" assinalam que "... a satanizaçao da mastigaçao da fol ha constituia um meio cômodo de evasáo da realidade da classe dominante boliviana, que viu nesta questao uma justificativa ideologica de sua dominaçao. Năo era pois a dupla exploraço 
social e racial a responsável pelo atraso, pela desnutriçă, pela insalubridade e pelo analfabetismo das maiorias indigenas bolivianas, senao a cocamania" (CANELAS e CANELAS $1983, P .110)$.

Como se pode ver, a condenaço da coca por parte da sociedade dominante, antecedeu e é independente da condenaça atual por parte dos paises capitalistas industrializados. 0 que estes fizeram foi proporcionar novos argumeritos para o ataque frontal contra o habito nativo que sempre resultou desagradável para brancos e mesticos.

\subsection{A comercializaçăo}

Durante o periodo colonial, os informes espanhóis descreviam o comercio da coca como sendo uma das grandes atividades comerciais da regiao andina. A coca, segundo CARTER E MAMANI (1986), era considerada responsável pela prosperidade da cidade de La Paz, considerada uma das mais ricas do Peru daquela epocals. Antes do auge da cocaina no mercado internacional, a producáo da coca na. Bolivia era destinada principalmente ao consumo domestico, e. uma pequena parte era exportada oficialmente a paises como Peru, Chile, Argentina, EUA, e outros. Durante a epoca colonial, os produtores de coca tentaram desenvolver o comercio com outros paises, mas so conseguiram comercializar

16 Durante a Época Colonial a atual Bolivia era conhecida como o "Al to Peru" pertencendo a uma mesma divisao politica com o "Baixo Peru", que é a tual República do Peru. 
alguma coisa nas provincias do norte da regiao do Rio da Prata.

A Independência, aponta DALENCE (1975), nao paralisou as exportaçoes. Houve eventuais interrupçes do comercio devido a problemas politicos com paises vizinhos, ocasionando dificuldades aos produtores e aos comerciantes da cidade de La Paz. Em 1846, a Bolivia exportou 7851 cestos 17 da coca ao Peru e 1200 cestos a Argentina.

Ja no presente seculo, de acordo com SPY (1928), a Bolivia exportou perto de $30 \%$ de sua produçao de coca as regibes produtoras de açúcar e de maça do Norte argentino e as minas de nitrato de Atacama no Chile; ambas as regiees contavam com grandes contingentes de trabal hadores bolivianos.

Entre 1920 e 1925 foram colhidos, na Bolivia, $16.346 .115 \mathrm{~kg}$ de folthas de coca. Desse total, a Bolivia exportou $13.22 \%$ (ou $2.161 .243 \mathrm{~kg}$ ) da seguinte forma, de acordo com a tabela 01 , apresentada a seguir:

$17 \mathrm{Na}$ época colonial um cesto equivalia a 20 libras, mas a partir do século XX foi alterada esta relaça passando a equivaler um cesto a 24 libras ou $11,04 \mathrm{~kg}$. 
Tabela 01. Exportạ̧a de coca boliviana, periodo 1920-1925

\begin{tabular}{lcc}
\hline Pais & Volume $(\mathrm{kg})$ & $\%$ \\
\hline Argentina & 1.897 .544 & 86,86 \\
Chile & 280.536 & 12,98 \\
Equador & 190 & 0,009 \\
Alemantia & 2.889 & 0,130 \\
Inglaterra & 84 & 0,004 \\
\hline Total & 2.161 .243 & 99,983 \\
\hline
\end{tabular}

Fonte: Carter e Mamani, 1986: 120

A "indústria da coca"19 na Bolivia, segundo os autores citados acima, foi afetada pela depressao dos anos 1930. Ela paralisou parcialmente a atividade da mineraçào causando uma aguda retraçăo no consumo doméstico deste produto. Isto aumentou a importancia relativa das exportaçes à Argentina, principal comprador da coca boliviana.

Em 1946, a Argentima, na tentativa de evitar a fuga de divisas, limitou consideravelmente sua importaça de coca a $410.000 \mathrm{~kg}$ e aumentou a vigilancia na fronteira com a Bolivia para evitar o contrabando deste produto. Consequentemente, as exportaçues bolivianas diminuiram de forma semelhante ao consumo Argentino, como se mostra na tabela 02, a seguir:

\footnotetext{
10 Por "industria da coca" Jeve-se entender, no presente trabalho, as atividades de produçao, secagem, empacotamento e comercializaçao da "folha de coca", tradicional e legalmente realizadas no pais, desde a época colonial. Nao deve confundir-se com o "processo de elaboraça da cocaina", que é uma atividade relativamente recente e considerada ilicita na Bolivia.
} 
Tabela 02. Exportaçao de coca boliviana, periodo 1944-1948

\begin{tabular}{l|c|c|c|c|c|c|c}
\hline \hline ANO & $\begin{array}{l}\text { Produc. } \\
\text { tot.de } \\
\text { coca t }\end{array}$ & $\begin{array}{c}\text { Coca } \\
\text { expor- } \\
\text { tada }\end{array}$ & $\begin{array}{l}\text { \% do } \\
\text { total } \\
\text { prod. }\end{array}$ & $\begin{array}{l}\text { Valor. da } \\
\text { coca ex- } \\
\text { port. (Bs) }\end{array}$ & $\begin{array}{l}\text { Valor tot. } \\
\text { de export. } \\
\text { agric.(Bs) }\end{array}$ & $\begin{array}{l}\text { Export.Coca } \\
\text { como\% da } \\
\text { export.Agr. }\end{array}$ \\
\hline 1944 & 4.651 & 444,06 & 9,5 & 12.450 .368 & 188.463 .245 & 6,6 \\
1945 & 4.434 & 417,19 & 9,4 & 5.407 .190 & 227.468 .790 & 6,8 \\
1946 & 4.857 & 418,12 & 8,6 & 19.134 .662 & 243.011 .269 & 7,9 \\
1947 & 4.533 & 385,71 & 8,5 & 15.367 .184 & 103.981 .564 & 14,8 \\
1948 & 4.229 & 361,36 & 8,4 & 13.983 .969 & 57.782 .560 & 24,2 \\
\hline
\end{tabular}

Fonte: Naciones Unidas, 1950: 91

Em fins de 1946, de acordo com SPY (1933), o valor de un tambor (46 kg) baixou de Bs 1200 a Bs 600 em menos de 6 meses. No ano seguinte, para superar esta situaça, a Bolivia e a Argentina assinaram um tratado de comercio no qual a última se comprometia a comprar um minimo de $600.000 \mathrm{~kg}$ de coca anualmente.

Tabela 03. Volume e valor das exportaçaes da coca boliviana, periodo 1938-1952

\begin{tabular}{lll}
\hline Ano & $k g$ & Valor (U5\$) \\
\hline 1938 & 392.737 & 269.855 \\
1939 & 406.314 & 213.753 \\
1940 & 402.672 & 217.160 \\
1941 & 347.250 & 190.080 \\
1942 & 339.190 & 204.172 \\
1943 & 380.473 & 191.435 \\
1944 & 444.064 & 260.487 \\
1945 & 406.397 & 317.075 \\
1946 & 418.122 & 400.336 \\
1947 & 385.714 & 321.513 \\
1948 & 251.358 & 292.573 \\
1949 & 316.479 & 505.266 \\
1950 & 214.198 & 341.327 \\
1951 & 119.010 & 190.781 \\
1952 & 166.208 & 467.094 \\
\hline
\end{tabular}

Fonte: Carter e Mamani, 1986: 122 
Como se pode ver na tabela o3 acima, a exportaçao de coca boliviana continuou diminuindo até a década dos 50. Já na decada dos 60 as exportaçoes foram aumentando. Em 1976, como se pode conferir na tabela 04, a seguir, a Bolivia exportou um total de $867.992 \mathrm{~kg}$ de folhas de coca, dos quais, segundo CARTER e MAMANI (1986), 799.592 kg $(92,12 \%$ do total exportado) foram destinados a Argentina e $68.400 \mathrm{~kg}$ (que representou $7,88 \%$ das exportaçoes de coca) aos Estados Unidas.

Tabela 04. Volume e valor da coca boliviana exportada, 19681976

\begin{tabular}{l|c|c|c|c}
\hline Ano & $\mathrm{kg}$ & Valor & US*/kg (*) & $\begin{array}{c}\text { indice } \\
(1968=100)\end{array}$ \\
\hline 1968 & 671.328 & 555.565 & 0,83 & 100 \\
1969 & 750.711 & 621.502 & 0,83 & 111 \\
1970 & 530.959 & 601.365 & 1,13 & 79 \\
1971 & 632.623 & 741.959 & 1,17 & 94 \\
1972 & 700.800 & 847.800 & 1,21 & 104 \\
1973 & 803.551 & 964.261 & 1,20 & 120 \\
1974 & 938.507 & 1.121 .729 & 1,19 & 139 \\
1975 & 819.927 & 1.028 .770 & 1,25 & 122 \\
1976 & 867.992 & 1.041 .936 & 1,20 & 129 \\
\hline \hline
\end{tabular}

Fonte: Carter e Mamani, 1986: 123

(*) Coluna calculada por F.O.H.B.

\section{5. Áreas de produçăo de coca}

Na Bolivia existem tres areas de produça de coca: i) a regiao dos Yungas, no Departamento de La Paz, ii) a regiao do Chapare, no Departamento de Cochabamba, e iii) a reyiao de Yapacani, no Departamento de Santa Cruz (ver mapa 2, p.60). Devido as pressoes internacionais para eliminar a 
produçan de coca excedentel-, as legisladores bolivianos definiram un criterio de discriminaça destas areas em funçao, principalmente, da antigüidade da cultura da coca, em cada uma destas regibes. Assim, na atualidade a produçăo de coca na Bolivia e: licita, na regizo dos Yungas; ilicita, na regizo de Yapacaní; e, licita até o mês de julho de 1993 , מa regizo do Chapare.

$\mathrm{Na}$ tabela os se mostra a evoluça da area plantada com coca no país, segundo as regibes. No caso da colonia de Yapacani nao existem dados disponiveis antes de 1986. Isto foi devido ao fato de que esta nao era uma regiao tradicionalmente produtora de coca no ámbito nacional.

Tabela 05. Area de produçao de coca na Bolivia, segundo regiao, periodo $1968-1987$.

\begin{tabular}{l|c|c|c|c}
\hline ANOIREGIAO & $\begin{array}{c}\text { VUNGAS } \\
\text { (ha) }\end{array}$ & $\begin{array}{c}\text { CHAPAFE } \\
\text { (ha) }\end{array}$ & $\begin{array}{c}\text { YAPACANI } \\
\text { (ha) }\end{array}$ & TOTAL. \\
\hline 1968 & 1.700 & 1.300 & $n . d$. & 3.000 \\
1971 & 1.800 & 2.650 & $n . d$. & 4.450 \\
1975 & 1.600 & 9.685 & $n . d$. & 11.285 \\
1980 & 6.418 & 16.370 & $n . d$. & 22.789 \\
1985 & 6.675 & 37.611 & $n . d$. & 44.286 \\
1987 & 8.913 & 51.198 & 845 & 60.956 \\
\hline
\end{tabular}

Fonte: Estrategia Nacional del Desarrollo Alternativo: $1.990, \mathrm{p} .43$

Ministerio de Asuntos Campesinos e Agropecuarios

19 Na Bolivia se denomina "coca excedente" aquela produça de folhas de coca cujo destino é a elaboraço ilegal de cocaina e næo o consumo tradicional de coca in natura da populaçăo. 
MAPA 2. REGIÕES PRODUTORAS DE COCA NA BOLIVIA, 1992

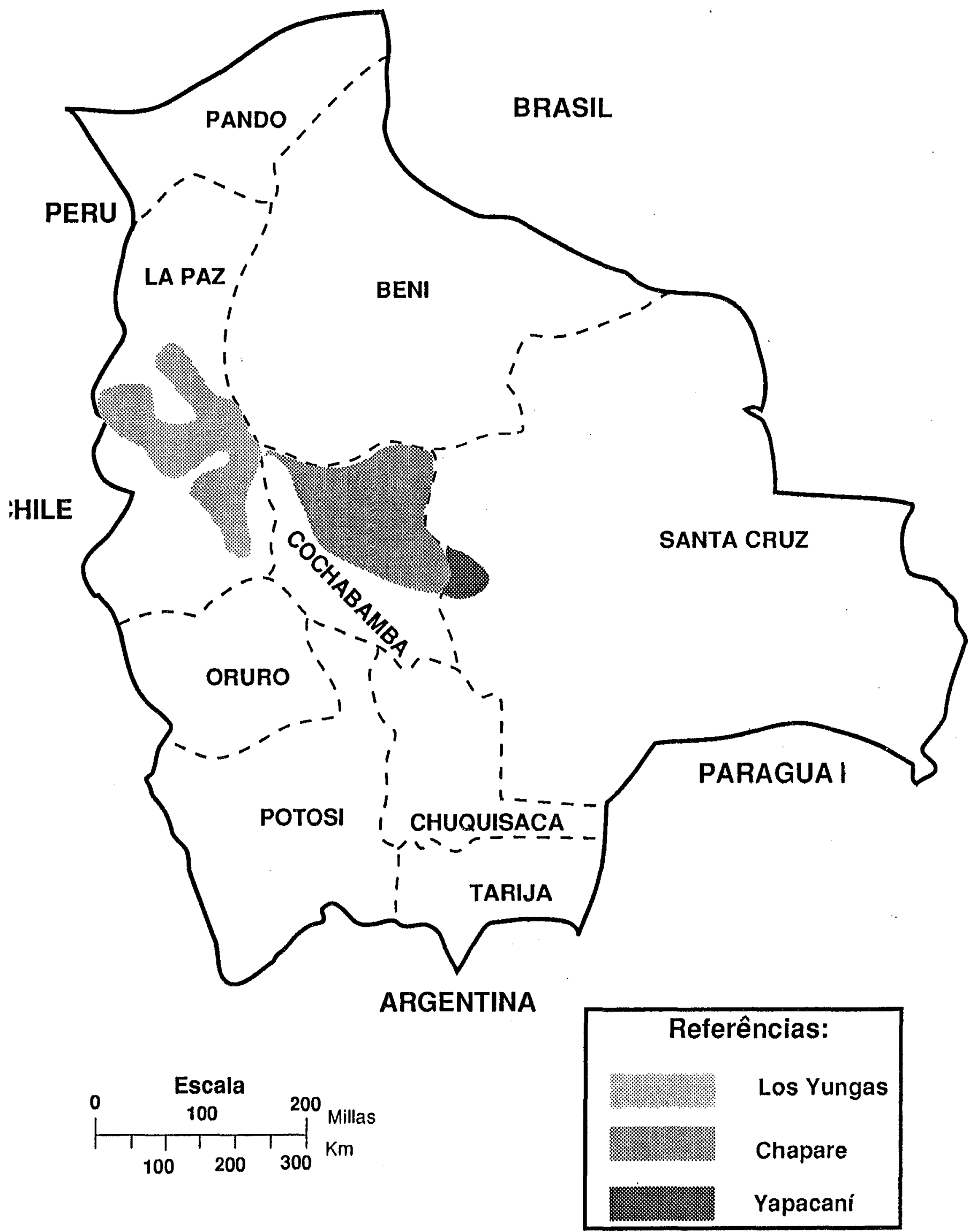


Como se pode ver na tabela 06, a seguir, a colônia de Yapacani representa só un por cento da área plantada com coca existente no pais, e $2 \%$ do volume da coca produzida em 1987. No entanto, sua importância radica em que, de uma parte, Yapacani poderia ter-se constituido num exemplo para outras colonias do Departamento de Santa Cruz. De outro lado, do ponto de vista do programa nacional de erradicaçao da coca, a experiência de erradicaçao executada na colonia Vapacani sera de grande importancia para a erradicacao da coca na regiao do Chapare, que e a principal regiao produtora de coca da Bolivia.

Tabela 06. Area, volume e participaçao percentual das regióes produtoras de.coca, ano 1987.

\begin{tabular}{|c|cc|cc|cc|c|c}
\hline GdelRegiao & Chapare & $\%$ & Yungas $\%$ & YAPACANf $\%$ & TOTAL \\
\hline Area (ha) & 51.198 & 84 & 8.913 & 15 & 845 & 1 & 60.956 \\
Prod. $(t)$ & 141.511 & 93 & 8.343 & 5 & 2.183 & 2 & 151.992 \\
\hline
\end{tabular}

Fonte: Elaboraça propria com base na Estrategia Nacional del Desarrollo Alternativo 1990: 44

Ministerio de Asuntos Campesinos e Agropecuarios.

\subsubsection{Regian dos Yungas}

Os Yungas de La Paz e uma regiăo considerada, na Bolivia, produtora tracicional de coca. Esta cultura foi importante, nesta regiao, desde epocas anteriores a conquista espanhola. Este produto, dada sua sigrificaçao 
económica, passou a ser de interesse para os conquistadores durante a época colonial. Posteriormente, a partir da Independencia da Bolivia, a produçao da coca passou as maos de fazendeiros estabelecidos nesta regiao. Como foi visto na seço 2.3, ate antes da Reforma Agraria (em 1953), os principais produtores da coca na Bolivia eram grandes fazendeiros que gozavam de poder politico, os quais criaram a famosa SPY.

Depois da Reforma Agraria de 1953, a produço de citricos e café foi incrementada as expensas da coca na maior parte dos Yungas. Os camponeses desta regiao preferiram reduzir o risco, evitando a excessiva especializaça numa única cultura. a governo boliviano em resposta ás pressges internacionais para controlar a produçao de coca, realizou alguns esforços nesta direça.

Atualmente a produçao de coca desta regiao continua sendo destinada principalmente a tradicional consumo doméstico. Devido a qualidade da sua folna de coca, ela é a preferida pelo consumidor tradicional, refletindo-se esta preferencia no seu preço maior en relaçá ao preço da coca produzida em outras regides do pais.

\subsubsection{Regizo do Chapare}

A producăo de coca no Chapare é relativamente recente se comparada com a regizo dos Yungas. A colonizaçăo da regiao do Chapare teve inicio na decada de 1910. No inicio, a cultura da coca era, ainda que importante, so um dos componentes da estrutura produtiva dos colonos do 
Chapare. Na década de 1960, segundo.flores e BlANES (1984), a cultura da coca já estava consolidada como uma importante fonte de renda monetaria. Contudo, a área média ocupada inicialmente era relativamente pequena (aproximadamente 0,5 ha). A partir do aumento súbito dos preços, ocasionados pela demanda de cocaina no mercado internacional, a tendência dos produtores foi produzir a maior quantidade de coca possivel, nao so paramelhorar a renda familiar mas tambem com o objetivo de diferenciaça social.

Ao contrário do que aconteceu nos Yungas e em Yapacani, o Chapare tem um economia orientada para fora. A maior parte do dinheiro gerado no chapare, pelos colonizadores, nao fica nesta regiao. Dai que, atualmente, os colonizadores nao têm mais interesse na melhoria da infraestrutura social. Para eles, na opiniao de florese Blanes (op. cit., p.140), "... o Chapare representa algo assim como um "centro de mineracao" onde se deve procurar tirar o máximo lucro possivel no curto prazo".

\subsubsection{Regiao de Yapacani}

Na regiao de Yapacani a produçao de coca foi ainda mais recente do que no Chapare. É que a solonizaçao de Yapacani foi ainda posterior a do Chapare. A produçao de coca nas unidades produtivas de Yapacani teve importancia apenas a partir da segunda metade da decada de 1970. 
Uma vez que a colónia de Yapacani encontra-se localizada no Departamento de Santa Cruz, onde o hábito de consumo de coca entre a populaçao nativa (guaranis) nå é ancestral como no caso da populaça de origem andina (quechuas e aymaras), considerou-se que a produçao de coca deveria ser proibida. Baseados neste argumento os legisladores declararam ilicita a produçao de coca na colonia de Yapacani. Deste modo, nesta colônia, procedeu-se a erradicaçao total da cultura da coca, a partir de jultio de 1989. 


\section{D DESENVLLVIMENTO AGR ICOLA DQ DEPARTAMENTO DE SANTA CRUZ}

\subsection{Antecedentes}

Segundo. LORA (1980), até fins do século passado, a Bolivia caracterizava-se por ter uma economia pre-capitalista. As relaçees sociais de produça na agricultura e na mineraça se baseavam no trabalio servil. A partir do inicio do presente seculo, com a articulaça do pais ao mercado mundial, como produtor de minerais, os centros urbanos comesaram sua transformaça experimentando uma relativa modernizaçao. No entanto, este pracesso nao toi dinamico devido a presença da economia de "enclave" consolidada na exploraça de minerais e geograficamente concentrada no Altiplano boliviano (principalmente nos Departamentos de Potosi. de La Paz e de orurol.

De outro lado, a organizaçao da produçao na agricultura, ate 1953 , continuava fundamentada no regime de servilismo. A falta de dinamismo neste setor se reflete na baixa taxa de crescimento da populaçao do Pais. Segundo MERIDA e SALDIAS (1991), entre 1900 e 1950 , esta foi $1,11 \%$ a.a. 


\subsubsection{Q "Plano Bohan"}

Em 1942 foi elaborado e apresentado ao governo boliviano o chamado "plano Bohan". Tal documento consta de um diagnóstico da economia boliviana ate aquela epoca, com enfase na analise dos cinco anos que vao de 1936 a 1940. Dele origina-se uma serie de recomendaçoes sobre estrategias, planos e projetos.

A importancia deste informe reside em ele ser a primeira tentativa, realizada no pais, para romper a politica oficial da dependendencia da economia na exploração e exportaçao de seus recursos naturais, principalmente os minerais.

No que diz respeito a agricultura, o "Informe Bohan" foi o primeiro a recomendar a substituicaro de importaçoes de alimentos ou produtos de origem agropecuaria. Deveria ser utilizada a capacidade financeira e administrativa do Estado para promover o auto abastecimnto. Com isso, as divisas obtidas pela exportacao de minerais, antes destinadas a importacăo destes produtos, seriam destinadas as outras importaçes mais produtivas, aumentando-se assim os baixos niveis de consumo de alimentos da populaçăo boliviana.

No conjunto, o "Informe Eohan" desenhou para a agricultura boliviana um modelo de desenvolvimento que, na opiniao de ARRIETA et alli (1990), parecia baseado nos conceitos de "desenvolvimento para dentro" e de "substituiçao de importaçles", caracteristicos do pensamento 
económico da CEPAL 20 , alguns anos antes da fundaçåo desta instituiçao. Este fato, surpreendente a primeira vista, e explanado do seguinte modo: "... a crise mundial dos anos 1930, ao provocar a diminuiça da entrada de divisas, somadas as restriçoes impostas pela segunda Guerra Mundial impuseram, na realidade latino-americana da epoca, a necessidade de superar os obstáculos para conseguir no exterior os bens e serviços necessários" (ARRIETA op cit, P.75)

o diagnastico do "Informe Bohan" enfatiza a extrema dependencia da economia boliviana decorrente de sua rigida condiça monoprodutora. O informe apontava o perigo que representava a dependencia da economia em suas exportaçoes de minerais; pois a.média änual da receita em divisas disponiveis, levando en conta a populaça total nacional (3.472.000 habitantes), representava so US\$7.48 por habitante/ano.

No quadro 1 apresentamos o saldo medio das importaçoes e exportaçóes. da Bolivia no periodo de 1936 a 1940. Entre as importaçes se destacam os produtos agricalas.

as Comiszo Economica para America Latina, organismo especializado das Naçôes Unidas para assuntos econônicos da regizo, criado en 1948. 
Quadro 01. Bolivia: exportaçoes e importaçoes

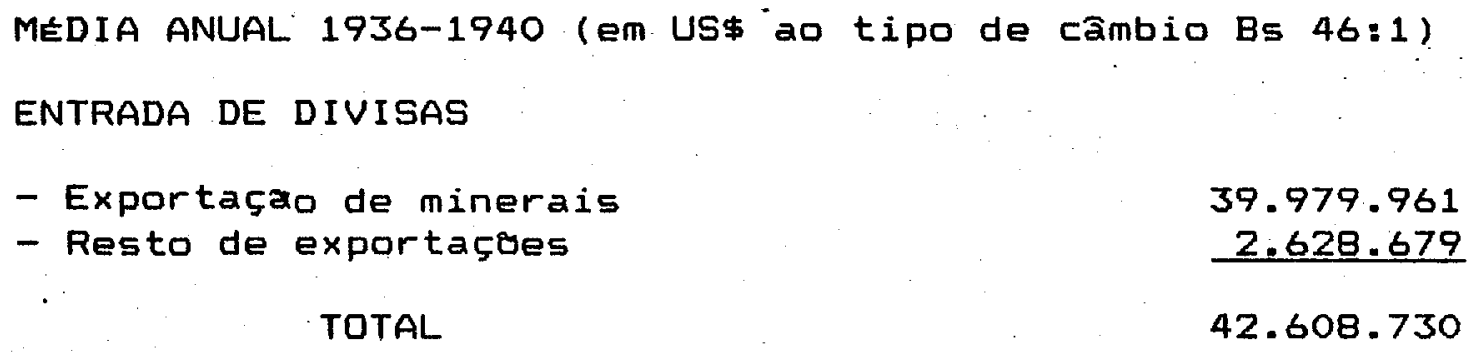

TOTAL

SAFDA DE DIVISAS

- Reposiça de maquinária e materiais, remesas ao exterior

- Importaça de produtos agricolas

13.992 .965

- Importaçao de manufaturas e outros

10.587 .809

- Disponivel p/gastos fiscais e do governo TOTAL

$\frac{12.590 .908}{37.171 .682}$

37.171 .682

$\frac{5.337 .048}{42.608 .730}$

42.608 .730

Fonte: Arrieta et alli, 1990: 77

$$
\text { En tais condiçôes, um - desenvolvimento }
$$

agricola que permitisse a substituiçao de importaçôs era uma necessidade do ponto de vista economico. Para atingir tal objetivo, o informe recomendava uma agressiva e ativa intervençå do Estado. No entanto, um investimento prévio deveria ser feito, na construçao de estradas que permitissem a articulaçă do pais, ligando, especialmente, a regiæo ocidental com a regiao oriental do país.

Noutros aspectos, o Estado devia modificar a sua politica impositiva, cedendo as terras privadas improdutivas (a maioria) para quem pudesse trabalha-las e redistribuindo a populaçao onde fosse necessário. Deveria, também, modificar sua politica de preços, estabelecenda 
estimulos para a produçao, mas sem subsidiar culturas de baixa produtividade.

Igualmente, teria que assumir a construça e administraçao de complexos agroindustriais bem como a produça direta das matérias-primas (caso do açucar), enquanto a produça privada nao se desenvolvesse o suficiente pará o auto-abastecimento. Recomendava, tambem, que o Estado se encarregasse da comercializaçao direta da produça, bem como da aquisiçao de equipamentos e insumos.

Por liltimo, BDHAN atentou para a urgente mecessidade da redistribuiça geografica da populaçăo rural do pais. A esse respeito, ele disse o seguinte: "Há um excesso de populaça agricola india em algumas partes da Bolivia apenas conseguindo uma auto-subsistência miserável. Esta populaçao poderia tornar-se colonizadora da Area de Santa Cruz, assumindo que a adaptaçăo ao novo ambiente seja viável. Nă sendo isto possivel, uma outra alternativa poderia envolver a participaçao de familias agricolas de outros paises para que se transferissem para Bolivia" BOHAN (op cit, p.142). E claro, entao, que existia no pais uma verdadeira necessidade de promover a colonizaçao do oriente boliviano para resolver o problema de escassez crónica de forca de trabalho desta regizo.

E preciso destacar o'fato de que em nenhuma parte do "Plano Bohan" se considerou a possibilidade obvia de que os potenciais rigrantes tornariam as áreas ocupadas em áreas potenciais de produçao de coca, dada a longa 
tradiçao de consumo deste produto, por parte da população de origem andina.

Era por demais sabido, naquela epoca, que a folna de coca constituia praticamente uma "mercadoria básica" na economia boliviana; o que implicava que o translado maciço da populaçăo andina para o Oriente boliviano so seria viável com um adequado fornecimento de coca. Se por qualquer circunstancia o preço desta mercadoria subisse, era dbvio que os colonos a produziriam para seu auto-abastecimento.

Como foi visto no capitulo anterior, quando indigenas bolivianos partiram para trabalhar nas colneitas dos paises vizinhos (Argentina e Chile), tais paises viramse diante da necessidade de importar coca para atrair esta forca de trabaliho barata.

Este fato émais uma evidência historica de que quando estiveram em jogo os interesses do "modelo de acumulaçao capitalista", pouca atencăo mereceram os argumentos eticos que em outras circunstancias foram utilizados com grande alarde.

\subsubsection{A Revoluçăo Nacional de 1952}

Diversos autores concordam en assinalar que o conflito belico (1932-1935) com o Paraguai (a Guerra do Chaco) foi um acontecimento de grande repercuço poíitica no interior do pais. A necessaria unificaça nacional, para 
enfrentar o inimigo comum, propiciou a uniao entre pessoas de classes sociais e de regibes diferentes até entao antagónicas, dando lugar assim ao surgimento do Movimento Nacionalista Revolucionário (MNR) partido "policlassista". Este partido politico assumiu a liderança no posterior processo de insurreicăo popular que culminou na Revoluçao Naciorial de 1952.

Na opinizo de FERNANDEZ et al1i (1991), o MNR tentava articular interesses sociais extremamente diversos dada sua ampla convocacaro sobre os atores sociais mobilizados, como parte de uma politica unificadora que no futuro resultou ser frágil. Isto devido a que nem todos os atores convergiam no "projeto politico" de construçao do capitalismo, tendo o Estado como única via para o desenvolvimento econamico e social do pais.

No dia 9 de abril de 1952, depois de sangrentos combates en diversos pontos do pais, o MNR assumiu o comando da Naçao com um maciço respaldo das populaçoes mineira, urbana e camponesa.

Tres meses depois, em 21 de julho, decretouse o Voto Universal, que incorporou mais da metade da populaçă adulta, especialmente camponesa, ao exercicio deste direito constitucional; en 31 de outubro do mesmo ano, decretou-se a Nacionalizaçæo das Minas: a 2 de agosto de 1953, decretou-se a Reforma Agraria (ABREGO op. cit, p:B3).

Na opiniao de PANIAGUA citado por FERNÁNDEZ (op cit, p.30), "a ruptura do modelo, através da aplicacáo 
tanto da. Nacionalizaçao das minas como da Reforma Agrária, foi um importante salto na consolidaçăo do mercado. Isto significava nao so liberar força de trabalio, mas tambem tornar viável, desde entao, o assalariamento geral e sobretudo a utilizaçao da moeda em quase todas as transaçôes".

\subsubsection{A Reforma Agrária}

Entre os abjetivos imediatos da reforma agrária se postulava: a) a resolucaa do problema da posse da terra; b) o melhoramento da qualidade de vida do produtor campones atraves da implantaçao de serviços produtivos e da substituiçăo de importaçoes; c) o melhoramento da produtividade e uma maior diversificaçao "e industrializaça da agropecuaria para garantir a seguranca alimentar do pais e gerar excedentes exportáveis.

No entanto, a partir do periodo pos-reforma, - camponés se converteu tanto no principal provedor de alimentos tradicionais, relativamente baratos, aos mercados urbanos; quanto no principal ofertante de forga de trabalino, tamben a baixo custo, ao estreito mercado de trabalho temporario criado pela agropecuaria e pela incipiente agroindústria capitalista.

Talvez por isso FURTADO (1978, p.301), conclui sua avalliaç da reforma agrária boliviana fazendo o seguinte comentário "... de um lado,' as comunidades rurais. nao estavam preparadas para aproveitar as oportunidades 
decorrentes das mudanças nas estruturas de dominação...; de outro lado, a Estado boliviano tampouco estava preparado para promover com êxito a criaçao de uma nova agricultura diferenciada da tradicional, capaz de produzir os excedentes necessários à expansao urbana".

Hoje, depois de quatro decadas da reforma agrária, o problema da insuficiencia de alimentos - para a grande maioria da populaçao rural boliviana - decorrente do modelo de modernizaçao com natureza concentradora de renda, ainda está latente. No caso dos colonos que conseguiram terra no Oriente boliviano se, no inicio, conseguiram certo alivio na sua pobreza, seus filhos agora sao tăo pobres quanto seus pais, devido a uma serie de fenomenos a serem analisados no capitulo seguinte. Eles se encontram diante de entraves tecnologicos e economicos dificeis de serem superados, pelo menos dentro do marco da legalidade.

Tal situaço, segundo GARCIA (1985, 0.48-9), se explica pelo fato de que "o objetivo final do modelo de modernizaçao náo e atingir un desenvolvimento globale harmonico da sociedade, mas a instrumentalizaça de um modelo de crescimento agricola capaz de responder, conjunturalmente, a domanda efetiva do mercado e as necessidades especificas do modelo de acumulaça:". 


\subsection{Evoluçao da estrutura agrária do Departamento de Santa Cruz}

A estrutura agrária do Departamento de Santa Cruz, antes da Revoluça de 1952, estava constituida por diferentes categorias de produtores agropecuarios, imersos em distintas formas de organizaça produtiva. 0 desenvolvimento da agropecuaria mercantil deste Departamento respondia as particularidades internas da região e do pais, pois os produtos de origem agropecuaria eram destinados exclusivamente ao mercado domestico.

Segundo SOLIZ (1991, p.35), "a causa do - particular desenvolvimento mercantil do Departamento de Santa Cruz, antes de 1952, foi o isolamento de que foi vitima com respeito ao poder do Estado oligarquico boliviano, prevalecente até. aquela epoca. o espaço territorial de dominacao ficava reduzido aos Departamentos produtores de minerais como La Paz, oruro e Potosi, e aqueles estreitamente ligados a estes Departamentos como Cochabamba E Chuquisaca".

So no final do seculo passado, no auge ta "borracha" no Norte do pais, o Departamento de Santa Cruz teve um breve florescimento. o significado foi, de acordo com MERIDA e SALDIAS (1991), uma reativaça da atividade agropecuária devido ao aumento da demanda de produtos agricolizs gerado por aquela atividade. No entanto, uma vez acabado o negócio da borracha, o Departamento voltou a situagao de isolamento e abandono anterior. 
De acordo com CORDECRUZ, "... até a metade do presente seculo, a cidade de Santa Cruz de la Sierra, capital do Departamento de Santa Cruz, tinha uma pequena populaçao carente de serviços públicos, sem indústrias e com um comercio incipiente orientado as necessidades limitadas de uma economia rural estagnada. Sua única comunicaçao com o mundo exterior era atraves de uma pessima estrada de terra (intransitavel em epoca das chuvas) a cidade de Cochabamba. Tampoco existia uma infraestructura viaria no interior do Departamento" (CORDECRUz 1975, P.8).

- rumo da economïa deste Departamento mudou consideravelmente a partir da Revaluçao Nacional de 1952 , quando o Estado oligárquico mineiro-latifundiario foi abalado. As principais medidas economicas que o novo Estado adotou foram inspiradas no "Plano Bohan". No quadro 02, pode-se observar a evoluça demografica da cidade de Santa - Cruz, no periodo 1900-1988. A elevada taxa de crescimento experimentada pelo Departamento de Santa Cruz, a partir da decada de 1950, e um bom indicador do processo inigratorio decorrente da diversifjcacao economica promovida pelo governo. 
Quadro 02. Cidade de Santa Cruz: evoluçao da populaçao, periodo 1900-1988

\begin{tabular}{|c|c|c|c|c|}
\hline \multirow[t]{2}{*}{ ANO } & \multirow[t]{2}{*}{$\begin{array}{l}\text { Populaçao da } \\
\text { cidade }\end{array}$} & \multirow[t]{2}{*}{$\begin{array}{l}\% \text { sob o total } \\
\text { do Departamento } \\
\text { de Santa Cruz }\end{array}$} & \multicolumn{2}{|c|}{$\begin{array}{l}\text { Taxa de } \\
\text { crescimento } \\
\text { cumulativa } \\
\text { anual }\end{array}$} \\
\hline & & & Periodo & $\%$ \\
\hline $\begin{array}{l}1900 \\
1950 \\
1976 \\
1988\end{array}$ & $\begin{array}{r}15.874 \\
41.461 \\
254.682 \\
570.335\end{array}$ & $\begin{array}{l}9,3 \\
16,9 \\
35,8 \\
51,4\end{array}$ & $\begin{array}{l}1900-50 \\
1950-76 \\
1976-88\end{array}$ & $\begin{array}{l}1,93 \\
7,23 \\
6,94\end{array}$ \\
\hline
\end{tabular}

Fonte: VARGAS 1991: 13

A implementaçao da Reforma Agrária e o "modelo de desenvolvimento", que visavam a substituiçao de importaçoes de produtos agricolas, inclüiram entre outras coisas uma rapida e adequada abertura de grandes areas cultiváveis até entao nå utilizadas.

Os principais fatores que tiveram um papel importante na iniciaça do processo de desenvolvimento regional, foram: "a conclusao de importantes obras de infraestrutura rodoviária e ferroviaria: a canalizaçao de assistencia tecnica e crediticia ao setor agropecuario da regizo; a politica de fomento da economia do açucar: o crescimento da exploraçao de petroleo: a imigraçao de agricultores de outras regibes e paises; a consolidaçáo de um marco institucional para o desenvolvimento e, a resposta positiva da iniciativa privada diante das oportunidades de investimento que começaram a se apresentar" (MERIDA e SALDIAS op cit, p.20) 
Apesar da falta de dados para estabelecer series historicas completas, alguns autores como ESCOBAR e SAMANIEGO (1981, p.17) assinalam que "...entre 1952 e 1954 - PIB deste Departamento passou de $2,6 \%$ a $9,1 \%$, en relacao ao PIB nacional. Logo, a partir da decada de setenta, esta porcentagem passou a estabilizar-se ao redor do 18\%" (ver tabela I.4, no apêndice 1 ).

Este desenvolvimento economico do Departamento de Santa Cruz provocou uma clara concentraça da populaçăo na chamada "área integrada", como se pode ver na seguinte tabela 07 .

Tabela 07. Departamento de Santa Cruz: distribuicăo da populaçao por provincias (porcentagens)

\begin{tabular}{|c|c|c|}
\hline PROV INCIA & 1976 & 1988 \\
\hline Populaça do Departamento & 710,724 & 1.110 .100 \\
\hline TOTAL & 100,0 & 100,0 \\
\hline Andrés Ibanez(*) & 44,5 & 58,4 \\
\hline Warnes (*) & 4,4 & 4,1 \\
\hline 0. Santistevan(*) & 11,1 & 10.4 \\
\hline $\operatorname{Sarah}(*)$ & 4,0 & 2,4 \\
\hline Ictilio(*) & 5.3 & 4,5 \\
\hline Sub-Total "Area Integrada" & 69.3 & 73,8 \\
\hline Chiquitos. & 4.7 & 2.3 \\
\hline Cordillera & 7.6 & 4,6 \\
\hline Velasco & 3,5 & $2 ; 7$ \\
\hline Vallegrande & 4,3 & 2,7 \\
\hline Florida & 3,0 & 2.0 \\
\hline Nuflo de Chávez & 4,7 & 3,2 \\
\hline Angel Sandoval & 1,1 & 0,8 \\
\hline M.M. Caballero & 1,8 & 1,0 \\
\hline Bush & - & 0,7 \\
\hline
\end{tabular}

Fonte: Elaboraçao propria com base em VARGAS 1991:10

(*) Provincias que formam parte da "area integrada" do Dpto. 
Como se pode observar na tabela acima, em 1976 e 1988 esta área concentrava $69,3 \%$ e 79,8\% da populaçao departamental, respectivamente.

\subsection{Categorias socio-econámicas de produtores rurais}

Segundo o lugar de origem, existem na subregizo integrada do Departamento de Santa Cruz tres categorias sócio-economicas de produtores: i) colonos

nacionaisłi; ii) empresários nacionais; $e$ iiil colonos estrangeiros. As caracteristicas mais importantes de cada um deles sao descritas a seguir.

\subsubsection{Colonos nacionais}

Entre as colonias nacionais, estabelecidas no Departamento de Santa Cruz, existem as dirigidas e as expontaneas. As dirigidas foram resultado das primeiras tentativas de colonizaçao do governo e contaram com uma planificaçăo e certo apoio técnico, economico e social. Já as sequndas nå tiveram tais facilidades. No entanto, foi a modalidade mais importante, a partir da dfeada de sessenta, pois os colonos expontaneos foram atraidos pelo dinamismo economico do Departamento.

\section{Em termos gerais a colono expontaneo} migrante: i) de outros Departamentos do pais, iil de outras Provincias do Departamento de Santa Cruz e, iiil da propria "area integrada". Trata-se de un produtor lou unidade

21 Esta categoria, a mais importante en termos sociais, esta constituida tanto por agricultores provenientes do interior do pais (Altiplano e Vales). como por camponeses do mesmo Departamento de Santa Cruz 
familiar) isolado ou temporariamente associado. Sua posse da terra é precária do ponto de vista juridico e também quanto ao uso da terra e da tecnologia empregada.

Desde o inicio utiliza recursos proprios oriundos da venda de pequenos excedentes elou da venda de sua força de trabaliho. Geralmente acupa os extremos da fronteira agricola e, conseqüentemente, as areas de pior infra-estrutura de transporte, de saude, de educaçao, etc.

- componente central de sua tecnologia é o "uso do fogo" complementado com algumas ferramentas como o machado, o facao e a enxada. Encontra-se marginalizado do credito oficial, mas nao do emprestimo lunto aos intermediários elou caminhoneiros. Seu vinculo com a mercado e geralmente indireto, tanto na hora de vender seus produtos quanto na hora de comprar seus insumos e bens de consumo.

Os colonos dirigidos, embora sujeitos ao mesmo padrao tecnologico do grupo anterior, tendem, pelo menos numa primeira etapa, a una maior estabilidade. A propriedade da terra, validada juridicamente, possibilita ocasionalmente obter algum credito do sistema financeiro nacional. No inicio do assentamento partem de uma base económica minima e recebem assistencia tecnica concedida pelas instituicoes organizadoras da colonizaçao.

Recebem serviças en termos de assistencia social, saude, educaçao, vias de acesso e transporte. No entanto, dada a falta de continuidade dos projetos e planos de governo (freqüentes nas economias latino-americanas), bem como o insuficiente suporte institucional, decorridas uma ou 
duas decadas de vida de uma colônia, torna-se dificil, para quem desconhece os antecedentes, encontrar diferenças entre uma colónia dirigida e outra expontanea.

De acordo com a classificacăo dos "sistemas de uso da terra"zi de BOSERUP (1987), no caso dos colonos nacionais, dirigidos ou expontāneos, e possivel identificar pelo menos duas categorias de produtores: il os que utilizam uma tecnologia tradicional, enquadrados no sistema "cultivo com pousio arbustivo"; e ii) os que usam diferentes graus de mecanizaça, enquadrados no sistema "cultivo com pousio curto".

\section{i) Produtores tradicionais ("pousio arbustiva")}

Em diferentes estudos, realizados nas areas de colonizaço do Departamento de Santa Cruz, tem aparecido, como caracteristica e problema central. a prática da "agricultura itinerante" baseada na tecnologia tradicional Ca "derrubada e queima" de florestas. Neste sistema, depois de aberta as clareiras nas florestas, as mesmas sao cultivadas com arroz por um ou dois anos, para logo serem abandonadas durante um periodo de o a 10 anos, dependendo de uma serie de fatores (clima, solo. mercado, etc.). Entre os problemas derivados desta pratica menciona-se,

az A classificaça de BOSERUP, em ordem crescente é a sequinte: "i) Cultivo com pousio longo ou florestal (20-30 anos de pousio); ii) Cultivo com pousio arbustivo (6-10 anos de pousio); iii) Cultivo com pousio curto (1-2 anos de pousio); iv) Cultivo anual (pousio menor que 1 ano); e, v) Cultivos maltiplos (sistema intensivo onde a mesma área suporta duas ou mais lavouras ano após ano)" (BOSERUP op cit, p.13-4). 
freqüentemente, o abandono de parcelas diante da dificuldade estrutural de inovaras.

No caso das colônias nacionais, segundo

Maxwell (1979), os fatores que explicam tal situaçă, såo os seguintes:

a) A escassez de capital e falta de acesso aos créditos de fontes oficiais que limitam a adoçao de nova tecnologia;

b) A falta de conhecimentos e experiência em culturas tropicais por parte dos migrantes do Altiplano e Vales, devido, em parte, aos insuficientes suportes institucionais fornecidos pela assistência técnica e pela pesquisa agricola;

c) A deficiente rede viária que limita o número de culturas comercialmente viaveis e que, ao elevar. os custos de transporte, reduz o retorno dos recursos -empregados pelo agricultor e sua familia;

d) O débil suporte de comercializaço que torna incertos os preços, tornando possivel uma transferencia de renda do agricultor para o intermediario e năo permitindo uma informaçå oportuna sobre o mercado; e

e) A má formulaçå dos planos originais das áreas de colonizaçao, que nå souberam eleger regiaes com melhores tipos de solos. Como resultado disso, muitas colonias estao localizadas en solos arenosos, nao apropriados para a cultura do arroz; outras encontram-se em lugares de 
precipitaçao pluvial insuficiente; e qutras ainda foram localizadas em áreas mal drenadas.

No entanto, resulta interessante confirmar que nas colónias nacionais existem também aqueles produtores que atingiram um maior grau de intensificaça nos seus sistemas de uso da terra, atraves da mecanizaçao parcial ou total. Dependendo de certas circunstancias favoraveis - tais como: bom acesso viario, disponibilidade de creditos com taxas de juros negativas, apoio técnico intensivo por parte de algumas instituiçoes nao-governamentais, etc. - alguns agricultores (aproximadamente $10 \%$ deles) encontram-se praticando sistemas mais intensivos de uso da terra, tais como "pousio curto" ou ainda "cultivo anual" (cf. nota. de rodape $\pi .221$.

\section{ii.) Produtores mecanizados ("pousio curto")}

A passagem da tecnologia tradicional a. mecanizacăo so e viavel quando convergem pelo menos algumas das vantagens assinaladas acima.

Noutras palavras, para transcender a fase de "pousio arbustivo" o agricultor precisa adotar nova tecnologia; no entanto, isso nao depende simplesmente de sua vontade mas de uma serie de fatores endogenos (capacidade técnica, base de recursos. saúde, etc.) e exogenos (mercado, preços, acesso a crédito e assistência técnica, etc.). 
De outrolado, nem sempre os colonos que atingem a mecanizaçao tem sucesso. STUTLEY (1982), baseado no seu estudo sobre mecanizaça feito na colónia ChanePirai, apontou como limitante desta opça tecnologica, a gradativa queda do rendimento da cultura de arroz. Segundo o citado autor, isto e resultado de uma combinaçao de fatores: i) crescente invasão de ervas daninhas, ii) perda da fertilidade do solo, e iii) compactaça do solo. Alén disso, aponta como problemas a monocultura de arroze a falta de uma cultura de inverno que permita tanto uma melhor distribuiçao dos custos fixos da maquinaria quanto a reduça da populaçao de ervas daninhas durante esta epoca do ano.

Dai ser reduzido o. numero de colonos racionais que atingem este nivel tecnologico e de capitalizaçao. Quando isso acontece, emerge simultaneamente um processo de diferenciaça social no interior da colonia.

\subsubsection{Empresarios nacionais}

O setor de empresarios nacionais tem origem na dissoluça da "Fazenda Tradicional". A partir da Reforma Agraria, o Estado estava disposto a reconhecer a posse da terra a pessoa que nela trabalhasse. Com issu, a presenca na fazenda de camponeses em condiczo de pedes ou "tolerados"ie era uma verdadeira ameaça para a integridade daquela.

Em vista disto, segundo ARRIETA et alli
(1990), teve inicio a expulsao da "fazenda" tos all

24. Camponeses que moravam no interior das fazendas na qualidade de colonos, com consentimento do proprietário. 
assentados. Mas, de outro lado, os camponeses ao serem expulsos viram a possibilidade, nao so de abandonar a "fazenda", a qual encontravam-se amarrados por diversos mecanismos, mas tamben de tornarem-se proprietarios de terra e produtores independentes; ou entao, de incursionar em novas atividades elou regibes como a povoado e a cidade. Destarte, a dissoluçao da "fazenda" foi pacifica. Tanto uns como outros acharam que ganhavam alguma coisa.

Uma vez dissolvida a fazenda como sistema, de acordo com a interpretaçao de ARRIETA (Op cit), aconteceu um fato interessante: tanto o fazendeiro quanto o pearo emancipado partiram da mesma base tecnologica. Ambos tiveram de concorrer no mercado, que ate entao era reservado ao patră elou aos intermediarios năo-camponeses.

Atualmente, de acordo com Horas et alli (1990), as chamados "empresarios nacionais" encontramise localizados nas áreas mais proximas dos centros urbanos e meinor dotadas de infraestrutura. Dada sua otima localizaçao, estas unidades empresariass tem um maior numero de opçdes de produça. Dai que, devido ao major risco, a cultura de arroz é geralmente cultivada so em terras baixas (suscetiveis de inundaça) onde năo e possivel estabelecer outra cultura. Outros produtores mantém o arroz como cultura pioneira em terras recém desmatadas, com o proposito de aproveitar a alta fertilidade do solo e a balxa incidencia de ervas daninhas, durante os primeiros anos de produça. Qbviamente, esta cultura tambem e produzida quarida, conjunturalmente, o seu preço se torna atrativo. 
Esta pode ser a razao, depois de quatro decadas, do empresariado nacional ainda manter muitas das caracteristicas tradicionais que fazem com que os seus custos (e riscos) de produçao sejam superiores aos dos colonos estrangeiros (Menonitas e Japoneses) que possuem a mesma qualidade de terras ou ainda inferiores.

\subsubsection{Colonos estrangeiros}

As colonias estrangeiras tiveram sua origem nos planos de diversificaçao económica e substituiçao de importaçôes executados pelo governo, a partir de 1952 . A ideia de atrair colonos estrangeiros para o territorio nacional era de que estes, alem de contribuir na produçao agricola, servissem tambem como agentes de difusao de novas tecnologias que pudessem ser adotadas pelos colonos racionais. No entanto, o ponto de partida quanto a base de recursas fai bem diferente.

As colonias estrangeiras, en termos de acesso ad capital, encontram-se mais proximas dos empresarios nacionais, só que possuem maior tradiçao agricola e conhecimento técnico.

A posse da terra está garantida juridicamente atraves das compras ao governo (no caso das colonias Menonitas e Russas) ou de dotaçdes (no caso das colónias Japonesas) 
No inicio, os colonos estrangeiros, sobretudo os Menonitas, utilizaram tecnologia intermediária (traçao anima1). Atualmente todas as colonias estrangeiras empregam tecnologia agricola moderna, com mecanizaça em praticamente todas as fases do cultivo. So costumam contratar força de trabalio para certas tarefas complementares, principalmente na capina e na colheita.

Outra diferença importante com relaço ao grupo anterior (empresarios nacionais), e a presença permanente do proprietário na unidade produtiva.

\subsection{A situação atual dos colonos nacionais}

Como foi antecipado, os colonos nacionais sao camponeses originarios do ocidente boliviano (Altiplano e Vales).

Uma vez que a cultura de arroz sempre foi importante para estes colonos, pois ela continua sendo cultivada mesmo com rendimento muito abaixo da media departamental, passa-se a descrever melhor certos aspectos relacionados com esta cultura.

\subsubsection{O arraz: cultura central nas unidades} produtivas

o arroz, segundo BUHAN (1942), era un dos dez produtos suscetiveis de serem produzidos internamente, aumentando-se a área elou o rendimento por área até o ponto 
de prescindir das importaçoes. Outros produtos agricolas, incentivados no Departamento de Santa Cruz, eram a cana-deaçúcar e o algodăo.

Quando se materializou a colonizaçao da zona Norte de Santa Cruz, as familias migrantes tiveram no arroz a principal cultura, já que ela era importante tanto no auto-consumo quanto na obtençao de renda. A opçao pela produçao de cana-de-açúcar foi mais dificil para a maioria dos colonos, dado que as terras aptas para tal cultura estavam principalmente nas mas dos antigos fazendeiros (agora pertencentes a categoria "empresarios nacionais") localizados ao redor das usinas - privadas e estatais instaladas na chamada "area integrada". Contudo, em termos de número de produtores do setor canavieiro, os colonos nacionais ainda constituen a grande maioria. Este fato foi muito bem utilizado pelos empresarios canavieiros na hora de negociar creditos, preços a custos de produçao com o governo. Este teve que assumir as perdas derivadas da bal xa competitividade do açucar nacional no mercado muridal. Conseqüentemente, o uso da estrutura de custos dos pequenos produtores como referência em tais negociaçöes, garantia uma margem dé lucro maior para os empresários nacionais.

Os primeiros inigrantes assentadọ na colonia

de Yapacani e outras colonias nacionais, que tiveram o privilegio de contar com floresta virgem e com um freco bom para a cultura do arroz, conseguiram atingir um grau razoavel de capitalizaçao. Inclusive alguns deles 
conseguiram passar a categoria seguinte (produtores mecanizados) ou viraran prosperos empresarios no setor comercial elou de serviços do "Comando" (principal centro urbano da colônia Yapacanil e outros povoados.

Ate aproximadamente a metade da decada dos 70, os preços do arroz eram atrativos e permitiam aos agricultores obter certa margem de lucro (ver tabela I.5, no apêndice 1, P.144). Nao obstante, a partir deste momento a demanda interna deste produto começou a se saturar e consequentemente deu lugar a uma queda no seu preço.

Cabe assinalar que na saturaçao do mercado doméstico de arroz, os "colomos japoneses" e os "empresarios nacionais", tambem estabelecidos mesta regiao, capitalizados e mecanizados, contribuiram aumentando sua produçao tanto pela via de incorporaçao de novas áreas quanto pela adoçao de novas tecnologias (novas variedades, controle quimico de pragas, etc.).

A saturaça da demanda domestica do arroz coincidiu com os problemas de reduça de rendimentos experimentados pels.s colonias nacionass mais antigas. Entre estas, a colónia Yapacani foi talvez a mais afetada, devido a. seus frágeis solos, principalmente da parte sul, que começaram a dar claras mostras de esgotamento. As altas precipitaçoes pluviais ( $3.000 \mathrm{~mm} / \mathrm{ano}$, em media) associadas ao relevo acentuado que cäracterizam estas areas, agora sem floresta, contribuiram a rápida degradacao do solo, que por sua vez, gerou uma sensivel reduçæo no rendimento do arroz. 


\subsubsection{A "crise do pousio" e a procura de saidas}

Em decorrencia do panorama mostrado na seçao anterior, a maioria dos colonos de Yapacani ingressou numa etapa muito dificil, vendo-se obrigados a procurar outras vias de desenvolvimento. Alguns tentaram sair deste impasse atraves da mecanizaçao, mas o resultado foi ainda pior. A perda de nutrientes do solo foi facilitada com o revolvimento da terra aremosa, caindo dramaticamente os rendimentos apos o primeiro ario de lavoura mecarizada. Dutros iniciaram um processo de diversificaça, introduzindo gado de leite e/ou de corte, incentivados pela assitencia tecnico-financeira de algumas instituicoses naogovernamentais presentes na colonia (Projeto Heiffer, FAO). Outros simplesmente limitaram sua producao ao ambito da subsistencia. Qutros ainda optaram pela emigraçăo para os centros urbanos ou procuraram terra virgem na fronteira agricola. Aqueles assentados nas proximidades do rio Yapacani tiveram sucesso com as plantaçes de banana, devido Mo enriquecimento do solo acarretado pelos sedimentos acumulados pelo rio. Por último. naquela epoca ja existiam tamben alguns agricultores que haviam encontrado ria cultura da coca uma forma de tornar relativamente estavel sua unidade produtiva.

As multiplas alternativas em experimentacao eram permanentemente avaliadas de modo informal pelos agricultores. Esta procura de alternativas passou a ser preocupaçao tambem de diversas instituiçoes governamentais e 
nao-governamentais (CIAT, CORDECRUZ, FAO, CIPCA, PROJETO HE (FFER ) .

Em 1978, a Centro de Investigación Agricola Tropical (CIAT), com assessoramento da Missao Britânica (MB), fez um diagnóstico de toda a área de colonizaça do Departamento, detectando aquilo que os agricultores $j$ á ha algum tempo estavam sentindo. Este diagnóstico batizou este impasse técnico-econámico dos agricultores, das diversas areas de colonizaçao, com o nome de a "crise do pousio". Acreditava-se que a causa do problema era principalmente de origem técnica. o argumento era que o insuficiente periodo de pousio fazia com que a ervas daninhas nao fossem razoavelmente eliminadas, dificultando assim o seu controle. Isto trazia como conseqüencia uma elevaçao dos custos de produçao, provocando ao mesmo tempo, uma queda no rendimento. das culturas.

Tambern existia a ripotese de que a carencia de nutrientes do solo cobertos com capoeiras era uma das causas importantes na queda dos rendimentos do arroz. No entanto posteriores estudos do CIAT mostraram que esta hipotese nao era constatável na maioria dos casos.

Em uma recente reavaliaçá da tese da "crise do pousio", THIELLE (1991) sustenta que tal teoria nao levou em conta a questao dos preços relativos da cultura de arroz, sendo esta a variável chave que explicaria, de modo mais consistente, o ingresso dos agricultores na referida "crise 
do pousio". Isto e, ná era so um problema de origem técnica, mas una combinaçao desta com a saturaçao do mercado que originou a "crise dos agricultores", pois ocasionou uma queda no preço e tornou inviável a inovaçao tecnológica nesta cultura. Cabe esclarecer que a saturaçao do mercado do arroz foi principalmente devida ao aumento da superficie e complementarmente ao aumento do rendimento por area dos agricultares mecanizados do Departamento, tanto estrangeiros quanto nacionais.

No entanto, parafins do presente estudo, o que realmente interessa e mostrar que os colonos de Yapacani, mais a grande maioria dos colonos do resto do Departamento, e a populaçao do pais em geral, enfrentavam na metade da decada de 1970 uma situaça. de aquda recessào económica. A zona de colonizaçao nacional foi praticamente abandonada a sua sorte. Neste momento estavam dadas as condicoes para que estes colonos se tornassem um contingente de forca de trabalho sustentadora dos mercados informals.e ilegais de trabalino.

No caso especifico da parte sul da colonia de Yapacani o panorama era talvez mais dramatico: os rendimentos da cultura do arroz eram comparativamente inferiores $(1.000-1.200 \mathrm{~kg} / \mathrm{ha})$ aos de outras areas de colonizaçao e da propria colonia de rapacani (1.800-2.200 kg/ha) (HOYOS et al1i, 1987).

Foi justamente a partir deste momento que teve inicio a atividade do narcotráfico de forma 
significativa no ambito nacional, tendo seu centro de operaços na regiao do Chapare. Os colorios de Yapacani que mantinham estreitos vinculos de amizade e parentesco com colonos daquela regizo vizinta, na qual o modelo de exploraçao agricola com o componente da coca, como eixo, já era bem conhecido, logo perceberam a viabilidade deste modelo na própria colonia de Yapacani. Foi assim que teve inicio um intenso processo de transferência tecnologica, de modo informal, que sem duvida teve um grande sucesso. Com o passar do tempo o preço da coca foi aumentando ate atingir niveis altamente satisfatórios para os produtores $=0$. No entanto, como se pode ver na tabela 08 , a seguir, nos últimos anos houve uma queda no preço devido à intensificaçao da interdiçao.

- Convém esclarecer, no entanto, que para os camporioses localizados em regiäes näo-protutoras de coca, a subita elevaça do preço da coca constituiu talvez o maior sofrimento de suas vidas. 0 presente autor tem informacoos de camponeses da Provincia Cordillera do Departamento de Santa Cruz, que durante a segunda metade do ano de 1979 (ano em que se intensificou visivelmente o narcotrafico), a coca toi substituida por "chicletes" durante varias semanas: 
Tabela 08. Evoluçăo dos presos da coca na Bolivia

\begin{tabular}{c|c}
\hline Ano & US\$/kg \\
\hline 1976 & 0,86 \\
1985 & 1,65 \\
1986 & 1,64 \\
1987 & 1,59 \\
1988 & 1,38 \\
1989 & 1,27 \\
1990 & 0,52 \\
1991 & 1,00 \\
\hline
\end{tabular}

Fonte: Elaboraçao propria com base em:

- LA ECONOMIA... (1991): p. 17

- DIRECO

E preciso esclarecer que os precos da coca obedecem não só a fatores de mercado. Eles saao altamente sensiveis a influencia de fatores relacionados ao clima socio-politico, particularmente as medidas de interdiçao do narcotráfico. Dai que, como apontam FLORES e BLANES (1984, p.174-5), ".. os preços acima sofrem grandes variaçoes ao longo do ano e, inclusive, ao longo do mês. Por exemplo. em abril de 1983, o preço passou de Bs. 1.09/kg de foltia de coca para Bs. $0.43 / \mathrm{kg}$ e en agosto do mesmo ano, o preco baixou de Bs. 3,04/kg a so Bs. 0.87/kg".

No entanto, dadas as vantagens ténicas e a escassez de opçôs agricolas, a coca năo demorou muito tempo em tornar-se o mais importante componente das unidades de produça da colonia Yapacani. As unidades produtoras de banana, como é sugerido na análise realizada pelo CIAT, em 1987, talvez se constituiram em uma exceça.

A incorporaçao da cultura da coca ra estrutura de produça significou para a grande maioria dos colonos de Yapacani, una saida vitoriosa da "crise do 
pousio". Ela garantiu, pelo menos no curto prazo, uma estabilidade das suas unidades produtivas e de toda a colonia, pois esta passou a ser uma regiao de absorçao de migraçöes.

\section{5. o periodo 1978-1982: a crise politica e a economia} da caca e seus derivados

É preciso relacionar agora as mudancas na estrutura de produça que estavam acontecendo nas áreas produtoras de coca com os acontecimentos sociais, politicos e económicos que o pais estava vivendo neste periodo.

De acordo com ARRIETA (op cit, p.121), "o conteúdo central dos confusos acontecimentos politicos que determinaram a queda do Governodo Gal. Hugo Banzer, bem como a variada sucessao de golpes, contragolpes e eleiçaesze, que tiveram lugar entre 1978 e 1982, nao e

26 A cronologia, ano por ano, a seguinte:

1978. Banzer e destitusdo por Pereda (21 de Julho); Pereda pelo Gal. Padilla ( 24 de novembro), o qual convocou as eleicoes.

1979. Eleiçaes. Diante da falta de vencedor absoluto $(51 \%)$, o Congresso deve eieger entre os candidatos mais votados. Depois de seis votaçoes sem acordo, toma posse o presidente do Congresso, Dr. Guevara ( 8 de Agosto). O Cel. Natusch depäe Guevara ( 1 de novembro). Ante a repulsa geral, entrega o poder ao Congresso, que nomeia a presidente das Càmaras, Sra. Gueyler (16 de novembro). Convocatória de eleiçơs.

1980. Eleiçöes ( 29 de junho). Nova falta de maioria absoluta. 0 Congresso se prepara para eleger o Presidente. O Gal. Garcia Mesa se adianta e depore Gueyler (17 de julho).

1981. Ante um levantamento da Guarniçăo Militar de Santa Cruz, dirigida pelo Gal. Natusch e o Cel. Añez, Garcia Mesa renuncia. Una Junta de Comandantes (4 de Agosto) designa Presidente um de seus integrantes, Gal. Torrelio (4 de setembrol.

1982. O Cel. Rico Toro, Comandante do Colegio lilitar de La Paz, se 
outro sená a resistência a abertura democratica e o "retorno aos quarteis" das forgas Armadas. Esta resistencia. foi exercida por certos grupos economicos, dos quais alguns militares faziam parte".

Na opinizo de ARRIETA (Op cit, p.121), "..este retorno à democracia, náo so era fruto longamente perseguido pelos movimentos populares, pelos partidos politicos, pelos setores de empresarios e pelos militares "constitucionalistas", como tambem resultado da pressäo externa, principalmente por parte dos EuA e da Comunidade Económica Europeia (CEE)".

Ainda o mesmo autor aponta o sequinte: ". mas ma realidade nacional havia um novo elemento. Dentre aqueles que resistiam as mudangas estavam os que nao o faziam por razbes exclusivamente politico-ideologicas ou na defesa de interesses minoritarios. Por baixo destas classicas motivacoes existia aqora um novo fator resporisay pela consolidaçăo e expansab da economia informal ou paralela" (ARRIETA op c1t. p.121). Surgia. agora. a producac e comercializacao de alcaloides, lou mais exatamente, da materia-prima para obte-los) a partir da folna de coca e da

proclama Presidente (19 de julho). Torrelio entrega a Presidencia do Gal. Vildoso. (21 de Jultio), que se viu obrigado a convocar o Congresso de 1980. Este, elege o vencedor da primeira maioria nas duas eleicoes consecutivas. Dr. Siles Suzzo ( 5 de outubro) que assume a Presidencia Constitucional ( 10 de outubro) (ARRIETA op cit, p.121). 
"pasta básica"z7. Essas, atividades passaram a ser genericamente conhecidas como "narcotráfico" e chegaram a ser reveladas ao público nacional e internacional no periodo de referência.

Poden ser muitas as causas que induziram o Pais a este processo, mas é indubitavel que a fracassada tentativa de desenvolvimento estabelecida pelo Estado a partir de 1952 e sustentada pelo apoio financeiro dos paises centrais, foi uma constante nao so na Bolivia como tambem no ambito da maioria das economiàs latino-americanas. Foi a partir deste momento que a Bolivia e outras naçoes ingressaram en um "novo modelo econamico de acumulaça capitalista", nao menos dependente que o anterior. Sobre o particular vale a pena a seguinte colocacao de SCHWARTz (1992, p.5): "Depois de uma decada de estagnaçăo econômica. a America Latina encontra nas drogas um modelo je crescimento que não cabe nas receitas convencionais de ajuste. Enquanto governos e economistas criam pacotes. modelos para o.mundo da economia formal, as sociedades encontram saidas para a sobrevivencia na realldade informal e paralegal".

Na nova divisao internacional do trabalio, aponta CAMACHO $(1991, p .98), "$ ".. a mäo invisivel do mercado

27 No processo de obtençăo de cocaina (cloridrato de cocaina). o passo inicial é a obtençăo de sulfato. Estima-se que de $300 \mathrm{~kg}$ de folhas de coca se obtém $3 \mathrm{~kg}$ de sulfato, de tres $\mathrm{kg}$ de sulfato se obtem $1 \mathrm{~kg}$ de "pasta básica" (óxido de cocaína), e, finalmente de un kg de pasta básica se obtém aproximadamente 900 gr de "cocaina" (BASCOPE 1982, p.24; FLORES e BLANES 1984, p.166-7). 
internacional encarregou-se, da mesma forma que fez no passado, de induzir os paises da periferia a produçao de materia-prima".

Ds camponeses produtores desta materia-prima țransferem excedentes a outros setores sociais, sem capacidade para negociar o valor do mesmo. A presença do capital do narcotráfico tem alterado caoticamente o padrao de desenvolvimento das regioes produtoras de coca. A subordinaça dos agricultores a este capital, assinalam FLORES e BLANES (1984), nå so provocou uma tendencia a monoproduçao de coca, mas tambem induziu as produtores ao processamento artesanal de "pasta básica", assumindo um risco cada vez maiorzo: De outro 1ado, MANSILLA e TORANZO (1991) advertem a decomposiçă dos vinculos primários com a terra e com a natureza assim como do sistema de solidariedade organica. Este universo tradicional foi substituido por uma modernidade de terceira categoria, que so possui as desvantagens e menhuma das virtudes do moderno capitalismo.

3.6. Algumas prováveis conseqüências da carencia de "Planej amento"

A partir dos diferentes planos de governo executados a partir de 1952, a denominada "área integrada" e

zo 0 ingresso ao "processe de verticalizaça" por parte dos produtores de coca, implica uma subordinaçao mais direta com o capital do narcotráfico e um enfrentamento aberto com as forças de repressão do governo. Maiores detalhes e inclusive evidencias fotográficas poden ser encontradas en CANELAS a CANELAS (op cit, anexos). 
a Cidade de Santa Cruz (capital do Departamento) transformaram-se num verdadeiro centro de absorçao de migraçäes.

- dinamismo adquirido pelo Departamento de Santa Cruz, segundo MERIDA e SALDIAS (1991), se reflete na taxa de crescimento da populaçao $(4,19 \%$ a.a.) que, para o periodo 1950-1976, e o dobro do experimentado pela população nacional. Muito mais importante foi a taxa de crescimento da populaçáo da cidade de Santa Cruz, da ordem de $7,23 \%$ a.a. Ela Ultrapassa claramente as taxas de crescimento das cidades de la Paz e Cochabamba, passando a ser, em 1976. a terceira cidade do pais en termos de populaça. Este fato revela a grande importáncia das imigraçoes no Departamento.

Entre 1976 e 1988, ainda de acordo com MERIDA e SALdias ( $O p$ cit), houve uma leve queda ma taxa de crescimento da cidade de Santa Cruz (cf. quadro 02, 0.76 ). No periodo 1976-1983, quando os primeiros sintomas da erise económica nacional se fizeram sentir (retraça das culturas da cana-de-açucar e algodao, inicio da inflaçao, etc.l, a taxa de crescimerito demografico total sofreu certa queda $(7,09 \%$ a.a.) e esta queda foi maior no periodo final durante a epoca da hiperinflaço $=15,22 \%$ entre $198 \%$ e 1988). Mesmo assim, neste periodo a cidade de Santa Cruz passou a ser a segunda cidade do pais, em termos de número de habitantes.

Nao obstante, este crescimento concentrado ma cidade de Santa cruz esta provocando um desenvolvimento 
caotico, com grandes deficits no fornecimento dos serviços sociais básicos. A seguir apresentam-se alguns indicadores que revelam a qualidade de vida que este dinamismo populacional oculta.

De acordo com o citado estudo de migraçao, emprego e moradia feito no centro urbano de Santa Cruz, temos o seguinte: .

Moradias

De acordo com VARGAS et alii (1991), a porcentagem de moradias deficientes e inaceitaveis englobava $30,8 \%$ do total de familias. No entanto essa porcentagem aumenta sensivelmente nos bairros periféricos (a urbanizaça dacidade tem forma anelada, partindo do núcleo central que constitui a área melhor dotada de infra-estrutura).

Disponibilidade de servicos básicos

No mesmo estudo de VARGAS ( $\left.O_{p} \sigma_{i t}\right)$, foi encontrado que $44,9 \%$ do total das familias da cidade carecem de agua encanada, no interior da moradia; $43,2 \%$ das moradias nao dispoem de banheiro para uso exclusivo dos membros da familia; $74,7 \%$ das moradias carecem de serviços de esgatos; e, finalmente, $14,6 \%$ das familias carecem de energia elétrica (isto acontece principalmente nos bairros novos) (ver tabela I.6, ro apendice 1, p.145). Nesta mesma tabela, tem-se que. $31,2 \%$ do total das familias da cidade de Santa Cruz carecem dos três se:-viços mais importantes para a saúde da populaçăo. De outro lado, observa-se também que a disponibilidade destes servicos diminui para os bairros afastados do centro da cidade. 


\section{Pobreza}

Com relaçao a pobreza, o citado estudo

revelou que $4,4 \%$ do total das familias de Santa Cruz. sæo familias indigentes; $35,9 \%$ sao familias pobires; e $56,1 \%$ das familias sao nao-pobres: Ver tabela 09 a seguir.

Imbela 09. Familias da cidade de Santa Cruz segundo nivel de pobreza, 1988

\begin{tabular}{lrr}
\hline NIVEL DE & TOTAL & DO TOTAL \\
POBREZA & FAMfLIAS & \\
\hline TOTAL & 120.006 & 100,0 \\
Indigentes & 5.274 & 4,4 \\
Pobres & 43.135 & 35,9 \\
Nao-pobres & 67,357 & 56.1 \\
Ignorado & 4,240 & 3,5 \\
\hline
\end{tabular}

Fonte: VARGAS 1991: 69

Observa-se, na tabela o9, acima. que $40,3 \%$ das familias da cidade apresentam renda insuficjente para cobrir suas necessidades basicas lou seja, sofrem de indigencia ou pobrezal. No entanto. se se considera a populaçao total (não so o mumero de familias), observa-se que esta porcentagem aumenta para $50,4 \%$. Isto é devido a conformaço mais numerosa das familias mais pobres (ver tabela 1.7 , no apēndice 1 , p.146).

\$0 criterio utilizado na determinaçäo da linhas de pobreza tol - sequinte: "i) Familias indigentes. Renda insuficiente fara alimentaço essencial minima; ii) Fanilias pobres. Renda acima da indigência mas insuficiente para gastos basicos de vestuario, moradia, educaço e outros; e iii) Familias nao-pobres. Renda superior ao custo. dos bens e servicos essenciais" (VARGAS op cit, p.68-9). 


\section{A colonia de yapacaní}

No presente capitulo serao reveladas as caracteristicas culturais dos colonos de Yapacani. A sequir, se situara esta coloria no contexto historico do Pais, relacionando-a com os planos do governo que lne deram origem. Serao mencionadas. tambem. algumas das circunstancias que propriciaram a consolidaçao das culturas de arroz e coca, prevalescente na maioria das unidades produtivas da colonia, antes. da execuça do programa de erradicacao de coca. Finalmente, serao apresentados os resultados do estudo empirico. Este estudo fol realizado numi momento de importantes mudancas da colenia de Yapacani, decorrentes da nova intervençao do governo.

\subsection{Aspectos culturais da colonia de Yapacani}

Uma das caracteristicas fundamentais do processo de coloniza-ao en Yapacani, ate os anos 1970, era sua configuraçao etnico-cultural. Fol um dos primeiros principais centros receptores da migraça do ocidente do pais. Os grupos de "quechuas" e "aymaras" mudaram as carateristicas da regiao, tanto no aspecto social quanto no 
fisico. o contorno natural foi alterado. 0 desmatamento da floresta e o desconhecimento de tecnicas apropriadas, para conduzir lavouras nos frageis solos com inclinaçoes pronunciadas e elevadas precipitaçoes pluviais, năo demoraram en traduzir-se em um esgotamento do solo. Houve, entao, uma queda sensivel na produtividade da principal cultura comercial e de auto-consumo dos colonos: o arroz. No aspecto cultural, os colonos de Yapacaní tiveram que assimilar certas mudanças na alimentaçao e na vestimenta. Tiveram que substituir, por exemplo, cereass como a quinua e tubérculos como a batata, tradicionalmente consumidos no lugar de origem. pelo arroz e a mandioca, respectivamente. Quanto as vestimentas, e provável que as mulheres tiveram que suportar o maior sacrificio. As tradicionais saias usadas no Altiplano nao as protegiam adequadamente da voracidade dos insetos do tropico, pelo menos durante o processo de adaptaça.

Porem, alquns. habitos eram demasiado importantes e praticamente nao tinham substitutos. Este toi - caso da mastiqaça da folta de coca. No entanto. os colonos de vapacaria tinham conhecumerito de que a coca era possivel de ser cultivada em rapacani, embora o produto fosse de menor qualidade en relaçao a obtida nas areas tradicionais dos Yungas de La Paz. Dai que alguns colonos decidiram introduzir plantas de coca, na colonia, para satisfazer suas necessidades de auto-consumo e, em alguns casos, tambem para a venda de pequenos excedentes no mercado. 
Como foi visto no capitulo anterior, este ultimo detaline cultural e o conhecimento da tecnologia da lavoura da coca pelos migrantes tornaram-se variaveis importantes no desenvolvimento socio-econámico desta colónia. Isto ficou evidente a partir do momento em que o crescimento da demanda provocou um aumento espetacular do preço da "foltia de coca".

\subsection{Arroz e coca: opçăo caótica perante a crise}

o "boom" do narcotrafico coincidiu com a
"crise do pousio" (maiores custos de producao e baxos
rendimentos do arroz) e com a saturaça da demanda de arroz no mercado nacional. O resultado foi uma reducáo do preco deste produto, fazendo com que a combinaça arroz/coca se transformasse numa opcao agricola que levou a fixacao do colono en sua parcela de terra, pelo menos no curto prazo.

o narcotrafico consolidou sua presenca nas proximidades de Yapacani. Instalou diversas unidades clandestimas de processamento industrial, onde as folhas de coca eram transformadas em pasta básica. A grande demanda de coca na regiao elevou o seu preşo a niveis que permitiam uma boa remuneraçao ao capital (ver quadro o3 e tabela $11,0.115$ e 117, respectivamente). Foi assim que a plantaça de coca se transformou numa atividade praticamente irresistivel para a grande maioria dos colonos de Yapacani. 
De acordo com os depoimentos dos agricultores, as vantagens da coca em relaçao as outras culturas sao as seguintes: tecnologia conhecida, baixo custo de implantaçao, alta rusticidade, precocidade, distribuiça da colneita ao longo do ano em quatro periodos, possibilidade de valorizaçă da força de trabalho familiar, baixa relaçăo peso/volume, bôa adaptaçăo as condiçós de solo da colónia de Yapacani, facilidade de transporte, facilidade de comercializaçăo, bom preço, melhor fluxo de caixa, maior rentabilidade, menor valor de capital de giro e possibilidade de obter lucro.

obviamente, nem tudo era vantagen. Existia a proibicáo a produça e comercializaça de cocaina e era por demais evidente que a demanda da folha de coca, na regiab, era destinada, principalmente, a fabricacao de pasta básica e cocaina. No entanto, ate a aprovaça da lei 1008 (vigente a partir de julho de 1988), nao existia luma proibicao legalmente explicita a producáo da coca no territorio nacional. Os colonos tamben nao achavam que era sua tunça o controle da delinquencia do Pais, menos ainda na situaço de abandono en que se encontravam. Por outro lado, a coca era considerada uma cultura tradicional na Bolivia e, portanto, nao havia razoes para eles se autodefinirem como delinquentes. Entzo, os colonos simplesmente se limitaram a seguir as sinalizaçoes de preço que o mercado emitia. Dai as plantaçoes da coca feitas, pela maioria dos colonos, em quantidades superiores as suas necessidades de autoconsumo. 


\subsection{Desenvolvimento planificado vs. desenvolvimento espontaineo}

A Colónia de Yapacani certamente seguiu a tendencia do Chapare quanto ao seu desenvolvimento económico. A preferencia pela lavoura da coca obedeceu a conjugaçao de fatores endogenos e exógenos como clima, solo, aspectos culturais, marginalizaça en relação a prestaçaode serviços públicos, mercado, entraves tecrologicos, entre outros. Sao fatores condicionantes que têm como denomiriador comum o subdesenvolvimento boliviano, onde a Estado nao tem condicdes de pôr en prática planos globais de desenvolvimento, que direciomem a iniciativa dos cidadaos.

$$
\text { Os colonos nacionais sao, em geral, }
$$

individuos que nao têm acesso as fontes de trabalho urbano e tampouco possuem, no lugar de origen, uma suficiente base de recursos para garantir a reproduço de sua forga de trabal ho familiar. Diante desta situaça; a partir de 1952, passou a existir a opça de migrar rumo as areas de colonizacao. l.a. seria possivel desenvolver estrategias de sobrevivencia. geralmente em condiçoes de extrema precariedade de recursos de capital e conhecimentos técnicos.

Por exemplo, os antigos colonizadores expontâneos, da vizinta regiao do Chapare, entraram naquela area quando nao existiam estradas. A distāncia e o clima obrigaram a maioria dos colonos, a depender da coca romo cultura comercial básica. Em tais condiçoes de isolamento, a coca era o único produto que - por sua facilidade de 
transporte, sua resistencia a perecibilidade, seu baixo peso e seu preso mais ou menos estável - garantia ao colono a possibilidade de conservar sua terra, ainda que com uma alta dose de sacrificio.

Neste ponto convém lembrar um pensamento de J.M. Keynes, durante a depressao economica mundial em 1930: "Ainda nao chegou o tempo de preferir o bom ao útil. Pór mais de cem anos, no minimo devemos simular para nos e para todos que o justo é injusta; pois a injusto é útil e o justo nao o e. Avareza, usura e precaucao ainda tem de ser nossos deuses por mais algum tempo. Pois so elas podem tirar-nos do tunel da necessidade económica para a luz do dia" e ainda acrescentou "o caminho para o ceu esta calcado de mas intençoes" (KEYNES 1930, citado por SCHUMACHER $1973,0.21$ ). Certamente esta foi a etica aplicada pelos colonos, diante de uma situacao de abandono e prostraço ma qual se encontravam. Em tais condiçoes. parece sem logica exigir deste tipo de agricultores um comportamento coerente com o "moralismo oficial". Macional. e internacional que $\equiv$ impoe na legislaçao recente.

Por outra parte. a colonia de rapacani fol parte do Projeto Nacional de Colonizaçăo que, por sua vez, fazia parte de um Plano de Desenvolvimento. Contudo, de acordo com o que foi visto no capitulo I (seçao 1.4), para que um Plano seja coerente e racional e necessário haver um processo iterativo onde o diagnostico seja constantemente reformulado a partir das periodicas avaliaçoes. 
No caso da colónia Yapacani fica claro que foi um processo de planificaça incompleto e, portarito; uma intervença estatal altamente irracional. Tanto que a presença da economia da coca na colónia foi percebida dez anos depois de estar plenamente estabelecida. Neste periodo, os agricultores ficaram praticamente sem direcionamento e sem apoio estatal.

Foi neste periodo que, diante da debilidade ou da inexistência dos subsistemas de apoio à atividade produtiva da agropecuária propriamente dita (assistencia técnica, credito, canais de comercializaço, unidades de processamento industrial de produtos agropecuarios, etc. $=1$, o narcotráfico organizou sua producáo de modo muito eficiente, aproveitando a experiencia ja existente entre os colonos com respeito lavoura da coca.

Usando a producăo e os conhecimentos tecnologicos que os colonos tinham. os "fabricantes de cocaina" se limitaram a estabelecer suas "unidades de processamento industrial" nas proximidades de rapacani. A finalidade era processar a produça de tolha de coca excedente desta colonia.

Ao mesmo tempo fol montado um eficiente subsistema de comercializaçao encarreqado da aquisiçăo da materia-prima e da posterior venda do produto processado.

o resultado foi que os agricultores optaram pelo desenvolvimento cadtico e de curto prazo no lugar de um 
desenvolvimento mal planejado e pessimamente executado. Como resultado, tem-se un paradoxo: a realidade está mostrando aos agricultores que foi graças a coca que a colônia está sendo objeto de reformulaçao do diagnóstico inicial e de execuçao de novas tentativas de desenvalvimento dirigida por instituiçôes governamentais.

Por enquanto, o que realmente aconteceu na colônia que o planejamento inicial foi inconsistente e descontinuo dando passo a "måo invissivel" que levou os colonos a produçå de coca. No momento em que os colonos ingressam num processo de acumulaçæo advindo do lucro gerado pela cultura da coca, o governo, diante. de pressaes internacionais, intervém novamente na colonia. Mas, como será visto a seguir, a improvisaço e a abordagem parcial do planejamento (desta vez chamado "desenvolvimento alternativo") novamente estao presentes nesta nova intervençå do governo.

\subsection{Resultados do estudo empirico}

De acorda com as informantes "chaves", na colonia de Yapacani existia, antes da execuça do programa de erradicaçao da coca, uma diversidade muito grande de produtores. Existiam desde aqueles que nao tinham nenhuma planta de coca, na sua unidade produtiva, até aqueles praticamente especializados nesta cultura. 


\subsubsection{Estrutura da produçăo antes da erradicaça}

Em um recente estudo de ABREgo et alli

(1990), realizado pouco antes da erradicaçao da coca em Yapacani, so 27 dos 153 agricultores entrevistados deram informaçao expontânea sobre a cultura da coca. No entanto, ficou evidente que o duplo cultivo "arroz/coca" era o mais comum nas unidades de produçæo da amostragem.

Com base na informaça das 27 colonos, do citado estudo de ABREGO et a111, que deram informaçes expontaneas sobre a lavoura da coca, encontrou-se uma area media de 0,60 ha para a cultura da coca e 2,68 ha para a cultura do arroz. No entanto, detectou-se uma certa correlaçao negativa entre a area da cultura da coca e a area da cultura de arroz; isto é, ria medida que a area media de arroz diminui, aumenta a area media plantada com coca (ver tabela 10 a seguir).

Tabela 10. Area media do Arroz e da Coca, segundo Sub-Regiaes da "Faixa Sul" da Colonia Yapacani.

\begin{tabular}{c|c|c|c|c}
\hline $\begin{array}{c}\text { Sub-regiao (*) } \\
\text { /Cultura }\end{array}$ & I & I I & II1 & $\begin{array}{c}\text { MEDIA } \\
\text { TOTAL }\end{array}$ \\
\hline ARRQZ (ha) & 3,30 & 2,78 & 1,86 & 2,68 \\
COCA (ha) & 0,30 & 0,72 & 0,69 & 0,60 \\
\hline
\end{tabular}

Fonte: ABREGO 1990: 119

(*) Neste estudo foi estudada so a "faixa sul" da colónia, a qual foi dividida em três sub-regioes: I, I I E III.

Segundo informaça verbal dos funcionários da Direçao Nacional de Reconversaa Agricola (DIRECO), orgao 
encarregado da erradicaça das plantaçoes de coca, antes da erradicaça existia una distribuiçăo bi-modal da área plantada com coca. Estes informantes mencionaram que a moda nas regibes de mais dificil acesso era maior do que a observada nas outras regibes. Nao obstante, a moda inferior éra mais importante no conjunto da colonia. Ainda de acordo com DIRECO, a área média plaritada na colonia nao superava um quarto de hectare.

A partir destes dados, pode-se concluir que ainda que a produço de coca desta area seja maior do que a necessária para o auto-consumo tradicional (estimada por DIRECO em 0,02 ha) - do ponto de vista da unidade produtiva como um todo, a cultura da coca era mais um componente da estrutura de produça do que uma monocul tura.

4.4.2. A marginalizaçáo dos naro-produtores de coca Como resultado da negociaçao entre o sindicato de camponeses produtores de coca $e$ os representantes do governo, aprovou-se um plano de erradicaçao de coca que teve inicio na colonia Yapacani. Como compensaçăo, us agricultores que optaram pela erradicaça voluntária tiveram direito a uma indenizaçao de US\$ 2.000/ha, mais uma opcao de credito ate tres vezes maior que a indenizaçăo, tendo como limite a quantidade de US\$ 6.000 por agricultor. A execuça da erradicaço e a indenizaçao foram conduzidas pela DIRECo e o crédito foi outorgado pela PL-480 (agência dependente da USAID, radicada na própria colónia). 
E interessante destacar o fato de que se outorgou um prazo aos agricultores para que eles procurassem voluntariamente o escritorio da DIRECO e declarassem a area de coca plantada e solicitassem a indenizaçao de US\$ 2000 por hectare a ser erradicado. Feito isso, os colonos recebiam da DIRECO um certificado que os convertia, automaticamente, em clientes com direito a credito na agência da PL-480.

Para a maioria dos agricultores a decisao de optar pelo esquema mencionado acima foi muito dificil. Eles estavam diante da ameaça, contida na nova lei loog, que convertia em delinquentes os agricultores que mantivessem suas plantaçoes de coca na colónia de Yapacani. Porem, segundo a informaçao fornecida pela DIRECo, em abril de 1992, mais de 40\% dos agricultores optaram por continuar com suas plantaçoses de coca desprezando, assim, a indenizaçao e o credito.

Houve agricultores mais "audazes" que optaram por ampliar imediatamente a área de coca en suas propriedades para, depois de estabelecida a plantacao, dirigir-se ao escritorio da DIRECO para solicitar a correspondente indenização.

Depois de jultho de 1990, a erradicaça das plantas de coca passou a ser forcada. Nessa situaça, o agricultor resistente perdeu o direito de compensacaa e, inclusive, da opçå de crẹdito. Muitos agricultores tiveram 
grandes prejuizos ao ficarem sem coca e sem opgao alguma para reiniciar sua atividade produtiva.

No entanto, existiam aqueles que por uma ou outra razao nunca tiveram coca na sua propriedade. Do ponto de vista destes agricultores era obvio que a politica de erradicaça da coca. era claramente absurda pois, na realidade, premiava-se o supgsto delinguerte castigando o inocerite. Dai que, diante das pressoes exercidas por estes agricultores, foi necessário que os planos de erradicacăo na colonia de Yapacani fossem reconsiderados por seus executores para incluir, no programa de credito de USAID. OS näo-produtores de coca (DIRECO, informe interno, 1991). 0 inacreditavel e que isto aconteceu em 1986 , na regiao dos Yungas de La Paz. Naquela ocasiao, un grupo de pequenos produtores de cafe - de una microregizo dos Yungas - que nazo produziam coca por oferecer esta cultura uma rentabilidade menor do que a do cafe, tiveram que introduzir. o plantio de coca para ter acesso ao Projeto "Agro-Yungas" do Programa das Nacoes Unidas para o Desenvolvimento (PNUD)

Neste detaline (repetiçao do mesmo erro) podese confirmar a falta de coerencia dos flanos do programa de "desenvolvimento alternativo". Esta atitude e tambem reveladora do carater parcial e excludenta que parece manter-se constante, apesar dos novos discursos. de "desenvolvimento alternativo" "coca de por dEsenvolvimento", tanto do governo quanto das instituicoes

3.x. Notas de campo do autor durante entrevistas realizadas com agricultores residentes na regiào dos Yungas, en $1: 87$. 
Internacionais mais interessadas na soluça definitiva deste problema.

\section{4-4.3. Renda do capital na cultura da coca}

De acordo com os dados obtidos no

"sondeio":\$4 de 1987, determinou-se a renda do capital na cultura da coca. Tanto em Yapacani quanto no Chapare o custo de implantaçao desta cultura e baixo se comparado com os custos de implantaçao da mesma cultura na regiao dos Yurgas. Naquelas regioes, a coca é implantada nas áreas desmatadas e destinadas inicialmente as culturas anuais como o arroz, o milho e a mandioca. De outro lado, a maior fertilidade do solo e a topografia plana permite sua implantaça direta, isto e, sem prévio preparo do solo. Nos quadros 03 e 04 (ver pp. 115 e 116), temos a estrutura de custos da cultura da coca para a colonia de Yapacani.

E interessante destacar o fato de que na cultura da coca o fator limitante e o controle de ervas daninhas. Dai que o controle quimico foi uma tecnologia rapidamente difundida, principalmente entre aqueles colonos desejosos de ampliar a area de cultivo. No entanto, existiam tambem aqueles produtores que nao utilizavam esta tecrologia, limitarido-se unicamente ao emprego da mao-deobra familiar ou contratada.

Para as finalidades desta analise, elaborouse o custo de produçao da coca utilizando-se dois tipos de controle de ervas daninhas: "com controle quimico" e "com

: Metodologia multidisciplinar de caracterizaça de sistemas de cultivo desenvolvida pelo Instituto de Ciencia e Tecnologia Agricolas (ICTA) de Guatemala. Trata-se de enquetes exploratórias modificadas, com caracteristicas próprias, como uma resposta as restriçoes de orçamento e de tempo. A informaçao obtida é de natureza qualitativa, a qual é posteriormente complementada do ponto de vista quantitativo (Uma maior informaçao pode ser encontrada em HILDEBRAlND e RUAMO, 1982) 
controle manual" (ver quadros 03 e 04, pp.115 e 116 , respectivamente).

Como já foi dito, a planta de coca e. uma cultura perene e a sua vida util varia segundo as condiços de clima e topografia. No caso da coca cultivada em Yapacani e Chapare, a plantaçao de coca é inicialmente consorciada com outras culturas (ver maiores detalhes, sobre os métodos de produçæo da coca, no apêndice II, p.147); conseqüentemente, os custos monetarios de implantaçao sao inexistentes. Os custos nao-monetários (canteiros, mudas e plantaçăo) de implantaçăo da coca foram estimados em US\$20 por $1 / 4$ ha. Admitindo uma vida útil de só 10 anos, teriamos uma depreciaçăo anual de USt 2 por $1 / 4$ ha de coca.

Como na colonia de Yapacani, a planta de coca começa a produzir 4 meses depois da sua implantaçao e, sendo baixo o seu custo de implantaçao (US\$ 20 por 1/4 ha), o fluxo de caixa gerado por esta cultura, nao apresenta cifras negativas mem para o primeiro ano. Nos quadros 03 a 04 apresentamos o cálculo da renda do capital ma para a cultura na coca, a qual da uma ideia da sua rentabilidade "com controle quimico" e "com controle manual".

35 Com relaçao do conceito de "renda do capital" pode-se consultar HOFFMANN et alli (1987, p. 62). 
Quadro 03. Renda do capital "com controle quimico" para a cultura da Coca em Yapacani, por 1/4 ha, 1987. (Em US\$)

I. Receita

Rendimento

Unidade

Preço

Qde. Total

( 4 safras)

Pacote * 11.96

20

239,2

II. Custos

Variáveis

165.75

Mao-de-obra

Aplic.Herbicida

Colneita

$1 H / D$

$1 H / D$

Secagem

$1 H / D$

Transporte

$1 H / D$

3.8

3.8

3.8

3.8

1.

6

1,5

2
33

1,25

Tot. Custo $M-D-O$

Insumos

Gramoxone

(1)

Custos Fixos

Depreciaçao

Ferramentas **

Asperssora ***

0,25

1,0

Custos Total

167.0

I I . Renda do capital (I-II)

72,2

Fonte: Elaboraça propria com base em CIAT, 1987: p. 42

* Um pacote equivale a 50 lbs. ou $23 \mathrm{~kg}$.

* No cálculo da depreciaça, o valor de mercado

das ferramentas (enxada e facao), foi

distribuido entre os 3 anos de vida útil

(estimado), e pela media de ha cultivadas

anualmente pelo colono.

** Neste caso, se procedeu da mesma forma que no

caso das ferramentas. So que a vida útil da

asperssora foi estimada em 5 anos.

Como a variável preço é muito sensivel, no

caso da cultura da coca, determinou-se o preço que iguala

receita e custo (o break-even-point). Assim, encontrou-se

que, ceteris paribus, o preço que iquala custo e receita

para o caso da tecnologia "com controle quimico" era de US\$

8,35/pacote. De acordo com isto, se observamos na tabela 11 
(p.117) veremos que a produça de coca, utilizando este sistema de produçăo, é uma atividade que ainda oferece altas possibilidades para se obter lucro.

Quadro 04. Renda do capital "com controle manual" para a cultura da coca en Yapacani, por 1/4 ha, 1987. (Em US\$)

I. Receita

Rendimento

(4 safras)

Unidade Preço Qde. Total

Pacote* 11.96

$20 \quad 239,2$

II. Custos

Variáveis

Mao-de-obra

Capina

Colneita

Secagem

Transporte

Tot. Custo $M-D-0$

Insumos

Gramoxone

11.96

20

Custos Fixos

Depreciaçao

Ferramentas *

Asperssora

Custos Total

$\begin{array}{ll}1 & H / D \\ 1 & H / D \\ 1 & H / D \\ 1 & H / D\end{array}$

1.
301,15

3.8
3.8
3.8
3.8

40
33
1,25
5

152,0

125,4

4,75

19,0

301,15

$-$

I I . Renda do capital (I-II)

Fonte: Elaboraçao propria com base en CIAT, 1987: p. 42 * Um pacote equivale a 50 l bs. ou $23 \mathrm{~kg}$.

* o valor das ferramentas (enxada e facao), foi

distribuido entre os 3 anos de vida util (estimado), e pela média de ha cultivados anualmente pelo colono.

No caso da cultura da coca "com controle manual", o preço que iguala custo e receita é de US\$ 15,07/pacote. Conseqüentemente, com 0 preço de US $\$ 11,96 / p a c o t e$, a renda do capital apresentou saldo negativi. No entanto, a rentabilidade nao e o único aspecto que interessava ao colono de Yapacani. Era importante também a 
propria geraça de emprego familiar (pois era uma forma de valorizaçao da måo-de-obra familiar que, em geral, tem poucas opçoes de trabaliho alternativo, sobretuido em determinadas epocas do ano). Isto explica o fato de muitos agricultores cultivarem coca ainda "com controle manual". Em ambos os sistemas de produça, se exclui o aluguel da terra. E que, em caso de nao haver coca, a invasao de ervas danintas, nas clareiras, vai impedir a continuidade das culturas anuais. Isso faz com que seja, praticamente, nulo o custo de oportunidade da terra.

Tabela 11. Preços medios da folha de coca na regiao do Chapare. Setembro/87 - Abril/92. (Em US\$/pacote)*

\begin{tabular}{|c|c|c|c|c|c|c|}
\hline MES \ANO & 1987 & 1988 & 1989 & 1990 & 1991 & 1992 \\
\hline Janeiro & & 15,23 & 30,98 & 7,61 & 12,78 & 12,64 \\
\hline Fevereiro & & 10,37 & 35,19 & 5,88 & 26,32 & 19.17 \\
\hline Mar5o & & 11,97 & 38.71 & $5,78$. & 34,13 & 22.93 \\
\hline Abri 1 & & 11,81 & 32,76 & $5,30^{\circ}$ & 25,55 & 19,88 \\
\hline Maio & & 15,87 & 31,09 & 8.65 & 19,12 & \\
\hline Juntio & & 28,06 & 30,71 & 13,97 & 26,33 & \\
\hline Jultho & & 52,15 & 36,23 & 17,53 & 17,90 & \\
\hline Agosto & & 59,05 & 43,62 & 22,42 & 21,59 & \\
\hline Setembro & 30,27 & 46,62 & 26.28 & 24,77 & 27.94 & \\
\hline Qutubro & 36,72 & 33,98 & 16,44 & 14.59 & 20.16 & \\
\hline Novembro & 33,81 & 48,05 & 14,69 & 10.29 & 25,54 & . \\
\hline Dezembro & 40,71 & 48,84 & 9,36 & 0,01 & 17.76 & \\
\hline MEDIA & 36,38 & 31,84 & 11.90 & 22,94 & 18,45 & 18.65 \\
\hline
\end{tabular}

Fonte: Elaboraça propria com base em registros da DIRECO * Un pacote equivale a $501 \mathrm{bs}$. ou $23 \mathrm{~kg}$

A tabela acima mostra que, en geral, a media anual dos preços da folna de coca, mantiveram-se ao longo dos últimos 5 anos, bem acima do ponto de equilibrio encontrado para ambos os sistemas de produça, mesmo no caso do sistema de produçao "com controle manual". 


\subsubsection{Renda do capital na cultura do arroz}

No caso da cultura do arroz, ao contrario do caso da coca, a tecnologia é praticamente homogênea. A estrutura de custos é a seguinte:

Quadro 05. Renda do capital na cultura do Arroz em Yapacani, por ha, 1987. (Em US\$)

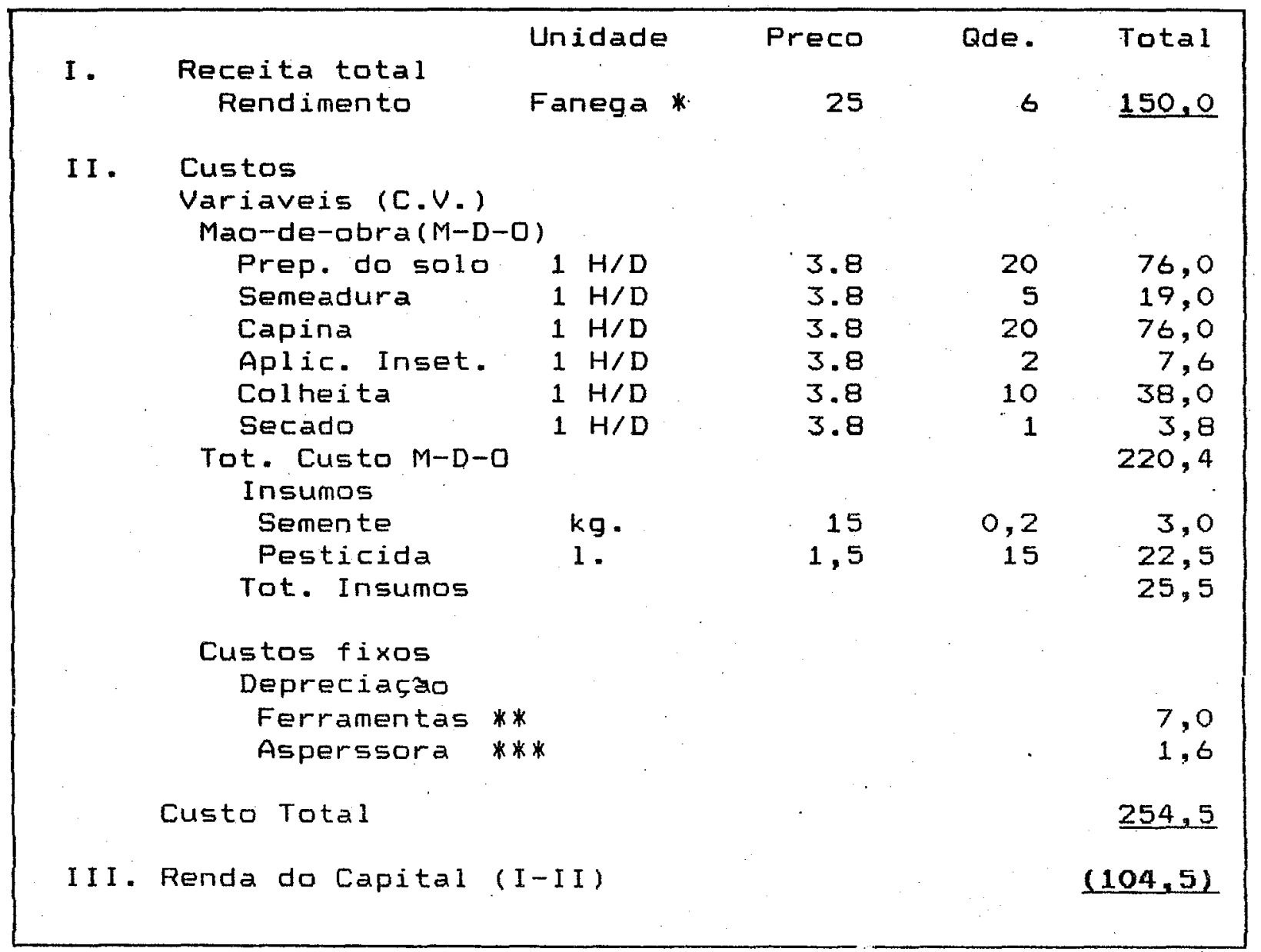

Fonte: Elaboracao propria com base em CIAT 1987

* Uma fanega equivale a $176 \mathrm{~kg}$

* No cálculo da depreciaça, a valor de mercado das ferramentas (enxada, machado, foice a facao), foi distribuido entre os 3 anos de vida útil (estimado), e pela média de ha cultivados anualmente pelo colonc.

* * Neste caso, se procedeu da mesma forme que no caso das ferramentas. So que a vida litil da asperssora foi estimada em 5 anos. 
Com os niveis de rendimento existentes na colónia, a produçao comercial desta cultura e praticamente desprezivel. Os colonos ja perceberam isso, há algum tempo. No entanto, a maioria deles mantem esta cultura como componente de subsistência, dentro de sua estrutura de producao. Como é sabido, para este tipo de produtor o objetivo da "subsistencia familiar" e talvez o mais importante. Isso explica o fato deles continuarem produzindo esta cultura, mesmo com rendimentos bem inferiores a media departamental e com "renda do capital" negativa.

\subsubsection{Dutras opçĐes de produçăo}

Entre as opçdes alternativas encontradas, em 1987, temos a criaça de gado de corte, gado de leite e banana. Atualmente, continuam as mesmas opçes de producao. mas sem a coca. Dessas alternativas so tem possibilidades de expansao a de gado de corte. De acordo com os depoimentos obtidos. no trabalino de campo. os creditos outorgados aos colonos. afetados pelo programa de erradicacalo de coca, foram aplicados, majoritariamente, na aquisiço de gado de corte e na ampliaçao de infraestrutura para esta finalidade. No entanto, a opça pelo gado de corte é de baixa rentabilidade, sendo preciso muito espaco em sistemas extensivos. As possibilidades le criaça intensiva de gado de corte nao e. sequer. considerada pelas estaçes experimentais. Dada a existencia de abundantes areas de 
terra, no Departamento de Santa Cruz, ainda e possivel produzir carne en sistemas extensivos.

Mas no caso dos colonos nacionais, se levarmos em consideraçao o fato de que as glebas são de 20 e $30 \mathrm{ha}$, e dificil pensar que esta opcao seja uma saida válida para a maioria deles. En todo caso, o que pode acontecer, nao existindo outras opçoes, é um processo de concentraçao da terra e una conseqüente diferenciaça social no interior da colônia.

No caso da produçăo de leite, existe o problema da saturaçáo do mercado. Atualmente, a produção de leite na colonia esta limitada por cotas. A indústria processadora de leite so pode comprar 4.750 litros nesta colónia. Esta cota de produço ja esta caberta pelos colonos que se encontram localizados perto da estrada central que divide a colónia.

No caso da produçao de banana, o solo limita sua produça, pois esta cultura se caracteriza por ser exigente en fertilidade. A opçao de fertilizacra artificial e considerada inviavel pelo CIAT, enquanio os preços dos fertilizantes permanecerem nos niveis atuais lo preco de fertiliząntes, no mercado boliviano, e de aproximadamente US\$ soo/tonelada).

4.4.6. Destino incerto do crédito Em conjunto com o programa de erradicacao. executado pela DIRECO, a PL-480 (instituiçao crediticia 
dependente da USAID) instalou-se ma colonia Yapacani com a finalidade de complementar o programa de erradicaça. o montante de crédito vai até US\$ 2.000 por ha, para os colonos portadores de certificados de erradicaçao, outorgados pela DIRECO. Na concessao de crédito, a preocupaçao fundamental nao era a apresentaçao, pelo beneficiario, de um projeto viavel para solicitar o credito. o que pesava era a apresentaço do certificado de erradicaçzo da DIRECO.

Esta observaçao foi confirmada nas entrevistas realizadas pelo autor, em abril de 1992. Alguns dirigentes da colónia comecam a perceber que o credito concedido tem uma finalidade implicita, que pouco tem a ver com un verdadeiro programa que possibilite aos colonos um desenvolvimento auto-sustentado. Assim, de acordo com as observaços dos entrevistados quanto a falta de planejamento e supervisao tecnica dos creditos concedidos, fica cada vez mais evidente que o objetivo implicuto do programa de credito foi principalmente exercer pressao sobre os agricultores, atraves dos mecanismos de cobrança, para impedir que eles voltassem a cultivar a coca.

De Ecordo com o relatado por alguns dirigentes da colónia, os produtores, na sua grande maioria, beneficiários da indenizaçao e do credito, fizeram péssimas alocaçoes destes recursos. E que eles nao foram acompanhados 
pela necessária orientaça técnica nem pelo fornecimento de insumos (mudas, sementes, pesticidas, etc.).

Mas a disponibilidade de crédito atraiu, como seria logico de se esperar, investidores que possuiam maior conhecimento técnico e mais informaçao de mercado. Deștarte, - que se pode esperar e o surgimento, na colonia, de um pequeno grupo de produtores (nao necessariamente colonos) que saiba tirar proveito desta conjuntura. De fato, de acordo com as informaçoses obtidas, isso já está acontecendo na colónia.

De outro lado, na epoca da entrevista (abril de 1992), alguns dos agricultores beneficiarios do crédito riao tinham condiçes de pagar os juros, depois de decorrido - primeiro ano de obtençáo do credito. .

De acordo com as informaçes obtidas junto aos entrevistados, os colonos que foram afetados por essas medidas já estáo percebendo que fizeram um péssimo negócio. Aceitaram tå facilmente a proposta da erradicaça, sem antes contar com uma atividade verdadeiramente alternativa que 1 hes permitissa uma passagem menos dramática a uma nova estrutura de produçao, sem a presença da coca. Aparentemente isto foi percebido por colonos da vizinha regizo do chapare, os quais, agora, estao adotando uma nova postura de negociaça com o governo: năo irao permitir a erradicacao da cultura da coca sem antes ter garantida uma renda satisfatoria com as opços alternativas propostas pelos agentes responsáveis. 
Na opiniao,de un colono, ex-dirigente da colónia, no momento do convênio com a governo sọbre o programa de erradicaçao da coca, os colonos pensaram só no futuro proximo e acharam interessante ter uma boa quantidade efetiva de dinheiro, que en muitos casos foi destinada ao consumo superfluo e improdutivo. Por outro lado, acreditavam que o programa de credito para a regiao teria sucesso. Existia tambem um certo temor na açao coercitiva e violenta desencadeada pelos orgaos de repressao ao narcotráfico.

\subsubsection{A opçao de continuar produzindo coca no}

\section{Chapare}

Um outro fenomeno previsivel era o de que os agricultores, que tinham um certo dominio na conducao da cultura da coca, isto e, aqueles que so viam na coca uma via de rapida capitalizaça, decidissem migrar à vizinha regiao do Chapare para continuar com a cultura da coca, uma vez que, nesta regiao, ainda e permitido o seu cultivo. No entanto, esta tendencia aparentemente foi menor do que se podia esperar. Indagando-se, sobre as possiveis explicaças para este fato, chegou-se a conclusaro de que nas últimas duas safras surgiram outras variáveis: a melhora substancial do preço do arroz nos últimos 2 anos (praticamente foi o dobro do ano anterior) e a queda do preço da folla da coca. Este último fenomeno foi devido a forte interdiça aos traficantes realizada na Colómbia en 1990 e 1991. 
Tamberm se deve citar a construço da estrada Chimore-Yapacani coma um importante fator de retença dos colonos, uma vez que houve uma revalorizaçăo automática das terras por causa das expectativas de um maior dinamismo comercial na colônia.

No entanto, num trabalio de tese realizado por CHAVEZ e HERRERA (1991), relata-se que 6 dos 18 agricultores entrevistados, nesta colónia, possuiam uma outra parcela na localidade de Bulo-Bulo, na área de influência do Chapare.

$$
\text { Isto significa que a opgao de continuar }
$$
produzindo coca naquela regiăo é perfeitamente viável para os colonos de Yapacani, principalmente depois da construçao da estrada que liga as duas areas. Um aprofundamento da crise tornará essa opçao mais viável ainda.

\subsubsection{A dificuldade da erradicaçăo definitiva da} coca

Segundo informacoes proporcionadas pelos funcionarios da DIRECO, que tambem operam na região do Chapare, atualmente é um fato evidente a existencia de uma "correlaçăo positive" entre interdiçăo e solicitaçao de erradicaçao voluntária de plantaçoes da coca. Isto é, quanto maior a interdicao aos traficantes de cocaina maior o numero de agricultores que procuram o escritorio da DIRECO para solicitar a erradicaça voluntária. Isto se deve ao baixo 
preço da folha da coca, resultante da repressao aos narcotraficantes, que diminuiu a demanda de coca.

Contudo, apesar das poucas plantaçoes de coca restantes na colonia de Yapacani (aproximadamente 50 ha, segundo os funcionários de DIRECO), está muito claro que o problema aindạ e latente. Por exemplo, existe a possibilidade dos agricultores voltarem a plantar coca depois da saida dos funcionários da DIRECO da colónia. E que ainda nao existem alternativas viaveis para a substituiça da coca na colônia. De outro lado, é provável que a volta da coca seja a única forma de pagar seus compromissos financeiros, já assumidos e, em muitos casos, sem respaldo produtivo. 


\section{CONCLUSÖES}

Ds resultadas do presente trabalino sugerem que: o problema da mudança na estrutura produtiva das unidades da colonia de Yapacani, onde a cultura da coca passou a ter uma maior importancia relativa, nos últimos quinze anos, foi devido a conjugaçăo de múltiplos fatores. Em ordem de importancia, temos os seguintes: planos do governo incoerentes e interrompidos, demanda crescente por coca, deterioraçao da terra depois do desmatamento inicial praticado pelos colonos (a terra tornou-se marginal para a cultura comercial do arrozl, condicoes agro-ecologicas favoraveis para a cultura da coca, escassez de opcoes agricolas técnica e economicamente viáveis, tradiçáo - dos colonos de Yapacani - de mastigaçăo da folha de coca.

\section{Planos incoerentes}

Us planos de governo, que deram orjgen a colonia estudada, partiram de diagndsticos parciais que posteriomente nao foram retro-alimentados, dado que a propria implementaça do plano foi interrompida. Somente quinze anos depois é que o governo descobriu que a cultura da coca tinha-se convertido na melhor opcao técnica e economica para os colonos. Na tentativa de redirecionar o rumo de desenvolvimento que estava seguindo a colania, elaborou-se um novo plano que tinha como objetivos 
explicitos promover o desenvolvimento auto-sustentado. No entanto, o que se observou foi que a principal preocupaçao do "novo plano de desenvolvimento" eira, simplesmente, a erradicaça da cultura da coca.

o que se pode apreender da experiencia da colonia Yapacani e a importancia de ser elaborado o "planejamento" da economia de um pais. As distorçoes que podem acarretar o laissez faire, podem ser perigosas, como no caso de Yapacani. Portanto, se o governo insiste em confundir "plano" com "planejamento" os resultados só podem ser parciais e efemeros. No entanto, pela forma como está sendo tratado o problema da coca no ambito nacional, tornase evidente a insistencia na execusao de "planos" desarticulados do contexto da economia departamental $e$ nacional.

A crescente demanda de folhas de coca

A demanda de folnas de coca para a elaboraça de cocainae, talvez, a variável que mais afetou o aumento da area plantada com coca na colonia de Yapacani. Sendo esta variável, determinada, em grande parte, por fatores exogenos, torna-se dificil o seu controle. Isto requer algumas reflexees. Segundo o ponto de vista do autor, a propensao ao consumo de um produto como a cocaina esta relacionada com certos aspectos estruturais do proprio sistema de produçao capitalista: A exagerada credibilidade 
no "sistema de preços", como mecanismo ideal de organizaçao da sociedade e de alocaça de recursos no sistema capitalista mundial, conduziu algumas sociedades aquilo que se conhece como a "moderna sociedade de consumo". Para satisfazer esta crescente demanda, as firmas tem que elevar sua produtividade. A concorrencia de mercado, onde em muitos casos a etica tem pouca relevancia prática, obriga as firmas a pensar no curto prazo, com o proposito de satisfazer a voracidade dos consumidores.

Esta estreita relaçao entre produça e consumo, já foi percebida por K. Marx. Ele disse: "A produça nao produz, pois unicamente o objeto do consumo, mas tambem o modo de consumo, ou seja, nao so objetiva, como subjetivamente. Logo a producao cria o consumidor;... Portanto, a produçáo náo cria somente um objeto para o sujeito, mas também um sujeito para o objeto" (MARX 1978 , P.110).

No entanto, ate agora, este problema fol encarado como um fenameno externo, tanto pelos paises "consumidores" quanto pelos paises "produtores". Esta visao caracteriza-se por ser dualista, parcial consequentemente, excludente. Sob esta visao, as paises demandantes de cocaina acham que se naa existisse a oferta da materia-prima (folhas de coca), nao haveria a demanda. De outro lado, os paises produtores de coca, seguindo o mesmo raciocinio, estao convencidas do contrário, isto e, acham 
que se nao existisse a procura por cocaina, no mercado mundial, a tradicional produçao de coca estaria limitada as necessidades de auto-consumo doméstico, no seu estado natural, nao existindo nenhum incentivo para aumentar a sua oferta.

Obviamente, nesta briga, como é natural que aconteça, o ponto de vista do mais forte que acaba prevalecendo. Diante deste impasse, é logico supor que a visao com que se está enxergando o problema é inadequada. Isto pode ser confirmado na pratica: o problema da produça, do comercio e do consumo de cocaina, longe de ter sido solucionado está tornando-se cada vez mais complexo e incontrolável.

Retomando o conceito de "planejamento", usado no presente trabalio, a forma como está sendo tratado o problema da coca excedente, na Bolivia, ainda permanece enquadrada nos antigos moldes, prevalecendo a parcialidade do enfoque. Destarte, pode-se concluir que: apesar de ter sido possivel eliminar a maior parte das plantaçdes de coca na colonia de Yapacani, o problema da coca excedente, no ambito nacional, ainda está longe de ter sido resolvido. Nada impede a mobilizaça geográfica dos agentes produtores. se isso for compensado economicamente. Isto nao é dificil diante da carencia de opçoes produtivas e/ou de emprego.

Baseado no que até agora aconteceu, pode-se predizer que o máximo que poderá acontecer ladmitindo o 
sucesso na "luta contra a cocaina", na Bolivial e uma mudariça na localizaçao geográfica do narcotráfico, isto é, um deslocamento da produçao para novos atores, novas regieges elou novos paises de mais dificil controle, ou entao, uma mudança nos gostos e preferencias dos consumidores para outras novas drogas provavelmente nao menos nocivas do que a cocaina.

Finalmente, de acordo com una visao sistêmica do planejamento, vemos que no ambito do desenvolvimento socio-económico mundial, nao adianta esquecer a existência de menhum pais, por pequeno que ele seja, pois a realidade esta mostrando que no interior de um sistema tudo encontrase inter-relacionado e em interaço.

Assim, enquanto, nao for bem entendido este conceito, a condenaçăo da produçăo de cocaina e ainda da coca, mesmo que ela esteja repleta de boas intençaes, está claramente desfocada. Em todo caso, o problema do tráfico de drogas deve ser considerado como uma grande advertencia ao grave perigo decorrente da visao reducionista, dualista, parcial e excludente embutida na tradicional forma de encarar o desenvolvimento, tanto no centro quanto da periférià do sistema capitalista atual.

\section{Vantagens comparativas da cultura da coca}

As vantagens comparativas da cultura da coca na colónia de rapacani ficaram evidentes. Até se poderia afirmar, dada a baixa fertilidade do solo da maior parcela 
da colônia de Yapacani, que será bem dificil encontrar, no curto e medio prazo, uma cultura com vantagens semelhantes. Uma vez erradicada a coca em Yapacani, nao apareceram, na colania, opçbes agricolas "democraticas", isto e, acessivel a maioria dos colonos. Nestas condiçoes, existe o perigo evidente de que os programas de desenvolvimento alternativo estimulem um processo de concentraçao da terra. Isto porque os colonos de Yapacani tem interesse na criaça de gado bovino. No entanto, pelos argumentos apontados, esta atividade requer uma extensao de terra bem maior do que aquela possuida pelos colonos.

Este conflito de interesses é un outro aspecto que deve ser levado em conta, tambem, na hora de o governo elaborar seus planos. Dar soluçao ao problema para um reduzido grupo de colonos implicaria em um simples deslocamento espacial do problema original.

A logica sugere, entao, que devem ser feitos verdadeiros esforgos nesta colonia, principalmente na pesquisa de alternativas agricolas acessiveis a maioria dos colonos. Esta pesquisa deve abranger desde o mercado até a pesquisa agronômica das alternativas selecionadas.

Tradiçăo de mastigaçăo da coca

Esta variável, ainda que importante pelo fato de ser a causa original da introduça pioneira das plantas de coca, nao tem muito a ver com o aumento da área plantada 
com coca na colónia de Yapacani. A área necessária de coca para o auto-abastecimento familiar é muito pequena.

No entanto, a erradicaçao total das plantaçoes de coca realizadas na colonia de Yapacani, negando inclusive uma pequena área para auto-consumo, contitui uma falta de sensibilidade e respeito ao hábito milenar destes colonos. A erradicaçao total nao é posivel. Tentar impor um comportamento impossivel de ser cumprido so conduz à hipocrisia.

\section{Visăo Nacional}

Na Bolivia, e necessario pôr un freio a produçao de coca excedente nao pelo simples afä de responder ao "moralismo oficial", claramente tendencioso dos paises centrais, mas sim como uma forma de liberar a populaçao rural do virus do dinheiro facil, da enganosa e perigosa ideia do "usufruto" sem "sacrificio", sem "processo. educativo". Esta expectativa ilusoria está afetando negativamente o sistema de valores de trabalho de boa parte da sociedade boliviana. o futuro de um individuo, de uma familia, de uma comunidade ou de uma naça, nao deve basearse en uma atividade envilecedora e subordinada ao capital internacional do narcotráfico. 


\section{REFERENCIA BIBLIQGRÁFICA}

ABREGO, G.; GAYA, E.; CLAURE, E. El impacto de la miqración Y la producción de coca en la zona de colonización Yapacani-Puerto Grether. La paz, Bolivia, AIPE/PROCOMCEDLA, $1990.189 \mathrm{p}$.

ARNT, R. Droga despertou o entusiasmo de Freud, que depois se arrependeu. Folha de Sao Paulo, Sao Paulo, 1 Nov.,

1991. (seção ciência) p.6

ARRIETA, M.; ABREGO, G.; CASTILLO, A.; DE LA FUeNTE, M. Aqricultura en Santa Cruz: de la encomienda colonial a la empresa modernizada (1559-1985). La Paz, Bolivia, ILDIS, $1990.374 \mathrm{p}$.

BALCAZAR, J.M. Historia de la medicina en Bolivia. La Paz, Bolivia, Ed. Juventud, 1956. $615 \mathrm{p}$.

BASCOPE, R. La veta blanca. Coca e cocaina en Bolivia. La Paz, Bolivia, Aqui, 1982. $189 \mathrm{p}$.

BOHAN, M. Informe de la Misión Económica de los EE.UU. a Bolivia. La Paz, Bolivia, 1942. 150.p. (mimea)

BOSERUP, E. Evolução agrária e pressão demográfica. Săo Paulo, Hucitec, 1987. $141 \mathrm{P}$.

BURCHARD, R.E. Una nueva perspectiva sobre la masticación de la hoja de coca. In: Carter $w$. (compilador). Ensayos cientificos sobre la coca. La Paz, Bolivia, Ed. Juventud, 1983. P.147-70.

CAMACHO, E. El narcotráfico es un problema social y politico que no se resuelve con la fuerza de las armas. In: Centro para el Estudio de las Relaciones Internacionales $y$ el Desarrollo (CERID). El impacto de capital financiero del narcotráfico en America Latina. La Paz, Bolivia, CERID, 1991.p.97-104. 
CANELAS, A.; CANELAS J.C. Bolivia: coca cocaina. Amigos del Libro, Cochabamba, Bolivia, 1983. $526 \mathrm{p}$.

CARTER, W.; MAMANI, M. Coca en Bolivia. La Paz, Bolivia, Editora Juventud, $1986.530 \mathrm{P}$.

CASTILLO, A.; CAMPEN, R. Apuntes sobre colonización. Centro de Estudios y Proyectos (CEP). Santa Cruz, Bolivia, Ed. Critica, 1981. $71 \mathrm{P}$.

CASTRO, J.L. La colonización y su impacto al ambiente. Enfogue agroecologico. Documento de campo $n .21$, Santa Cruz, Bolivia, PROGRAMA de las NACIONES UNIDAS para el DESARROLLO (PNUD)/FAO/BOLIVIA, 1986. $52 \mathrm{p}$.

CHAVEZ, L.; HERRERA, E. Sistema mejorado de produccion agricola: una alternativa al sistema de corte y quema para pequeños aqricultores de la zona de Yapacani. Santa Cruz, Bolivia, UNIVERȘIdAD AUTONOMA GABRIEL RENE MORENO, 1991. $203 \mathrm{P}$.

CORPORACION REGIONAL DE DESARROLLO DE SANTA CRUZ

(CORDECRUZ). Macrodiagnóstico regional de Santa Cruz. Santa Cruz, Bolivia, CORDECRUZ, 1975. $175 \mathrm{p}$.

DALENCE, J.M. Bosquejo estadistico de Bolivia (1846). La Paz, Bolivia, Edit. Universitaria, 1975. 369 P.

DANDLER, J. El desarrolio de la agricultura, politicas estatales $y$ el proceso de acumulación en Bolivia. In: Estudios rurales Latinoamericanos. Bogota, Colombia, Ed. Impresora Gráfica Ltda., 1984, v.7, n.2, p.20-39.

DEL OLMO, R. La geopolitica del narcotráfico en. America Latina. In: Centro para el Estudio de las Relaciones Internacionales $y$ el Desarrolio (CERID). El impacto del capital financiero del narcotráfico en America Latina. La Paz, Bolivia, CERID, 1991. P.29-67.

DIRECCION NACIONAL DE RECONVERSION AGRICOLA (DIRECO). Informe qestion 1991. Santa Cruz, Bolivia, DIRECO. Yapacani, 1991.23 p. (mimeo).

DUKE, J.; AULIK, D.; PLOWMAN, T."Nutritional value of coca". Botanical Museum Leaflets, Harvard. University, 1975, $v$. 24, n. 6, p. 113-19.

LA ECONOMIA de la coca en Bolivia: Plaga o salvacion? La Paz, Bolivia, Müller \& Asociados, 1991. 22 p. 
ESCOBAR, J.; SAMANIEGO, C. Agricultura, requerimientos y disponibilidad de fuerza de trabajo en Santa cruz, Bolivia. Ministerio de Trabajo y Desarrollo Laboral, Proyecto Migraciones y Empleo Rural y Urbano (OIT/FNUAP), Serie Resultados n.2, La Paz, Bolivia, 1981. 177 p.

FLORES, G. e BLANES J. Donde vá el Chapare?. Cochabamba, Bolivia, Ediciones CERES, 1984. $273 \mathrm{p}$ :

FERNANDEZ, J.; PACHECO, P.; SCHULZE, J.C. Marco de interpretación de la cuestion agraria en Bolivia. La Paz, Bolivia, CEDLA, $1991.98 \mathrm{p}$.

FERNANDEZ N. La coca boliviana: maravillosas propiedades y cualidades de la coca. Opiniones de prestiqiosos medicos y naturalistas acerca de la planta sagrada de los Incas del Perú.La Paz, Bolivia, Ed. América, 1932. 153 p.

FRANCO, M. Informe gestión 1991. Santa Cruz, Bolivia, DIRECO, 1991. 23 P. (mimeo)

FURTADO, C. A economia latino-americana. Sao Paulo, Companhia Editora Nacional, 1978. $339 \mathrm{p}$. .

Gagliano, J. A. "The coca debate in colonial Peru" The Americas, July, $1963,0.43-63$.

GARCIA, A. Modelos operacionales de reforma agrária y desarrollo rural en America Latina. Costa Rica, IICA, 1985. $196 \mathrm{P}$.

GUTIERREZ N., C. Acción de la coca sobre la actividad mental de sujetos habituados. Revista de medicina experimental, Lima, $v$. III, n.1, P. 1-18, 1944 .

HILDEBRAND, P.; RUANO, S. El sondeg. INSTITUTO DE CIENCIA Y TECNOLOGIA AGRICOLAS (ICTA), Guatemala, 1982. $15 \mathrm{p}$.

HOYOS, F.; THIELLE, G.; CHOCLO, D.; ARDAYA, D. SOndeO Yapacani Sur: Resultados y recomendaciones para $1 a$ investiqacion $y$ extension. Documento n. 67, Santa Cruz, Bolivia, CENTRO DE INVESTIGACION AGRICOLA TROPICAL (CIAT), 1987. $65 \mathrm{p}$.

HOYOS, F.; DAVIES, P.; REYES, N.; GONZALES, G.; TANAKA, T. Dominios de recomendación para la investiqacion en las zonas arroceras de Santa Cruz. Documento $n .75$, Santa Cruz, Dolivia, CIAT, 1990. $77 \mathrm{p}$.

HUNT, E. Historia do pensamento econômico. Rio de Janeiro, Editora Campus, 1989. 541 P. 
IGLESIA EVANGELICA METODISTA EN BOLIVIA. La vida agricola en las colónias: un estudio econômico de diez colónias al Norte de Santa Cruz. Santa Cruz, Bolivia, 1972. 83 P.

INSTITUTO NACIONAL DE ESTADISTICA (INE). Resultados del censo nacional de poblacion $y$ vivienda 1976, Departamento de Santa Cruz. Vol.7, Talleres Gráficos Offset INE. República de Bolivia, 1981.

INE. Resultados provisionales del Departamento de Santa Cruz. I I censo nacional agropecuario. Santa Cruz, INE, 1987. $82 \mathrm{P}$.

INE. Resultados provisionales del Departamento de Santa Cruz por cantones de Provincias (1992). Santa Cruz, INE, 1992. $75 \mathrm{P}$.

JORDAN P., R. Coca, cocaina, interdicción y narcotráfico: prevención, curación, represión, militarización, desarrollo, legalizacion y cocaina sintetica: crisis. Revista Estado Sociedad, La Paz, Bolivia, n.7, p.11-58, 1990.

LORA, G. Formación de la clase obrera boliviana. La Paz, Bolivia, Ed. Masas, 1980. $171 \mathrm{p}$.

LANGE, $\quad 0$. Economia socialista e planeamiento economico. Buenos Aires, Ed. Rodalfo Alonso, 1972. 86 P.

MANSILLA, F.; TORANZO, C. Economia informal y narcotráficon. La Paz, Bolivia, Instituto Latinoamericano de Investigaaciones Sociales (ILDIS), 1991. $113 \mathrm{p}$.

MANZANO, A. Capacidad agricola de las tierras de colonización Yapacani-Puerto Grether. La Paz, Bolivia, Ministerio de Agricultura, 1964. 100 p.

MARX, K. Para a critica da economia politica. In: Os Pensadores. Ed. Abril Cultural, Să Paulo, 1978. 404 P.

MAXWELL, S. Colonos marginalizados al norte de Santa Cruz: averidas de escape a la crisis de barbecho. Santa Cruz, Bolivia, CIAT/MISION BRITANICA (MB), 1979. 58 p. (Documento de trabajo $\pi .4$ )

MAYER, E. El uso social de la coca en el mundo andino: contribucion a un debate y toma de posicion. In: Carter w. (compilador). Ensayos cientificos sobre la coca. La Paz, Bolivia, 1983. P.211-28. 
MERIDA, A.; : SALDIAS, E. Migración hacia la ciudad de Santa Cruz. Santa Cruz, Bolivia, CORDECRUZ/PREAL/OIT, 1991. 334 P.

MENDOZA, G. "El empleo de la coca en Bolivia". Estudios Sociales. La Paz, Bolivia, 1941, n.2, p.76-81.

MORTIMER, G.W. History of coca "the divine plant of de Incas". San Fransisco, EUA, Fitz Hugh Ludlow Memorial Library Edition, 1974. $385 \mathrm{P}$.

NACIONES UNIDAS. "Informe de la Comision de Estudio de las hojas de coca, mayo de 1950". Lake success, New York: Consejo Económico y Social. Actas oficiales, duodécimo periodo de sesiones. Suplemento especial n.1, 1950. 135 P.

NACIONES UNIDAS. "The Commission of enquiry on the coca leaf". Bulletin on Narcotics n.1., 1950, p.39-41.

NELSON, M. The develoment of tropical lands: policy issues in Latin America. Baltimore, United State of America, The Johns Hopkins University Press, 1973.. 306 p.

QUIROGA, J.A. Coca/cocaina: una visión boliviana. La Paz, Bolivia, AIPE/PROCOM-CEDLA, 1990. $129 \mathrm{p}$.

RAMOS, P. Qbjetivos e instrumentos de la politica económica. La Paz, Bolivia, 1983. $133 \mathrm{p}$.

SCHULTZ, G. Minicenso Antofagasta. Santa Cruz, Bolivia, PNUD/FAO, 1983. $55 \mathrm{P}$.

SCHUMACHER, E.F. Q negdcio é ser pequeno. Sao Paulo, Ed. Circulo do Livro, 1973. 271 p.

SCHWARTZ, G. Droga cria nova economia. Folha de Sao Paulo. Sao Paulo, 26 Jan., 1992, p.5 (seçăo 4).

SOCIEDAD de Propietarios de Yungas (SPY). Informe del señor Ezequiel Romecin C. a la junta qeneral de 11 de febrero de 1928. La Paz, Bolivia, Imprenta Cervantes, 1928. 81 p.

SPY. Memoria presentada a la junta general ordinaria del dia 6 de marzo de 1933 por su presidente Sr. Abel Soliz S. La Paz, Balivia, Ed. America, 1933. $415 \mathrm{p}$.

SOLIZ, E. Tierras, campesinos y capitalismo en Santa cruz. Santa Cruz, Bolivia, Editurial Universitaria, 1991. 103 p. 
STUTLEY, C. Estudio sobre 105 problemas de destronque $y$ mecanización en la zona de colonización de Chane-Pirai al Norte de Santa Cruz. Documento n.34, Santa Cruz, Bolivia, CIAT/MB, 1982. $78 \mathrm{p}$.

SZMRECSÁNYI, T. Q planejamento da agroindústria canavieira do Brasil (1930-1975). Sao Paulo, Hucitec/UNICAMP, 1979. $540 \mathrm{P}$.

THIELE, G. Revision de literatura de la zona de colonización de Santa Cruz -Parte I Deste. Santa Cruz, Bolivia, CIAT, 1990, DOC. ח.78. $51 \mathrm{P}$.

THIELE, G. La crisis de barbecho: una re-evaluacion. Santa Cruz, Bolivia, CIAT, 1991. 63 P. (Informe tecnico, n.1)

TORANZO, C. Bolivia: reproducción de capital y politica. Santa Cruz, Bolivia, Ed. Universitaria, 1989. 306 P.

VARGAS, M.; MANSILLA, A.;JUSTINIANO, J.C. Vivienda, pobreza $y$ condiciones de vida. Santa Cruz, Bolivia, CORDECRUZ/FNUAP/OIT/PREALC, 1991. 182 P.

WHITAKER, M; VILLEGAS, c. Perspectivas económicas de la substitucion de coca por frutas citricas y cafe en el área de Chulumani, Yungas en Bolivia. La Paz, Bolivia, Documento de trabajo No.007/76, Ago., 1976. 29 p. 


\section{APENDICE 1 (Tabelas)}


Tabela I.1 Número e área das unidades agropecuárias, por Provincia e segundo uso agricola.

\begin{tabular}{|c|c|c|c|c|c|c|}
\hline \multirow{2}{*}{ Provincias } & \multicolumn{3}{|c|}{ Area tota 1} & \multicolumn{3}{|c|}{ Área agricola } \\
\hline & $\begin{array}{l}\text { Unidades } \\
\text { censadas }\end{array}$ & ha & $\%$ & $\begin{array}{l}\text { Unidades } \\
\text { censadas }\end{array}$ & ha & $\%$ \\
\hline Total Dpto & 42.345 & 5.525 .095 & 100 & 38.488 & 614.321 & 100 \\
\hline A. Ibañez & 5.969 & 226.620 & 4,1 & 5.425 & 91.155 & 14,8 \\
\hline Warnes & 2.988 & 113.450 & 2,05 & 1.496 & 44.958 & 7,32 \\
\hline Velasco & 3.827 & 1.026 .028 & 18,57 & 2.693 & 20.396 & 3,32 \\
\hline Ichilo & 4.605 & 220.264 & 3,99 & 4.266 & 106.486 & 17.33 \\
\hline Chiquitos & 2.213 & 866.977 & 15.69 & 1.638 & 25.030 & 4,07 \\
\hline Sara & 1.814 & 150.231 & 2.72 & 1.534 & 48.262 & 7,86 \\
\hline Cordillera & 4.297 & 1.018 .790 & 18,44 & 3.739 & 50.903 & 8,29 \\
\hline Val legrande & 3.532 & 118.240 & 2,14 & 3.477 & 19.555 & 3,18 \\
\hline Florida & 2.955 & 80.010 & 1,45 & 2.834 & 12.389 & 2,34 \\
\hline Santiesteban & 3.228 & 189.003 & 3,42 & 3,011 & 87,766 & 14,29 \\
\hline$\tilde{N}$. de Chavez & 6.801 & 1.014 .099 & $18 ; 35$ & 6,582 & 74,234 & 12,08 \\
\hline A. Sandoval & 820 & 459.834 & 8,32 & 579 & 26.015 & 4.23 \\
\hline M. Caballero & 1.306 & 41.558 & 0,75 & 1.214 & 5.171 & 0,84 \\
\hline
\end{tabular}

Fonte: elaboraça propria com base em dados preliminares do segundo censo nacional agropecuario (INE, 1987). 
Tabela I.2. Provincia Ichilo: número e área das unidades agropecuárias por tamanto das propriedades e segundo uso agricola

\begin{tabular}{|c|c|c|c|c|}
\hline \multirow[b]{2}{*}{$\begin{array}{l}\text { Tamanho das } \\
\text { Unidades (ha) }\end{array}$} & \multicolumn{2}{|c|}{ Area total } & \multicolumn{2}{|c|}{ Área agricola } \\
\hline & $\begin{array}{l}\text { Unidades } \\
\text { censadas }\end{array}$ & ha & $\begin{array}{l}\text { Unidades } \\
\text { censadas }\end{array}$ & ha \\
\hline Total Provincia & 4.605 & 220.264 & 4.266 & 106.486 \\
\hline Sen terra & 8 & - & - & - \\
\hline Menor de 0,10 & 202 & 11,7 & 6 & 0,5 \\
\hline De 0,10 a 0,19 & 10 & 1,2 & 10 & 1,2 \\
\hline De 0,20 a 0,49 & 39 & 9,7 & 34 & 8,4 \\
\hline De 0,50 a 0,99 & 86 & 48,4 & 73 & 41,2 \\
\hline De 1 a & 143 & 169,8 & 130 & 142,6 \\
\hline a 2,99 & 81 & 168,4 & 77 & 149,8 \\
\hline a 3,99 & 56 & 171,6 & 52 & 142,5 \\
\hline 4,99 & 34 & 138,7 & 33 & 122,7 \\
\hline 529,99 & 114 & 724,9 & 110 & 608,8 \\
\hline 10 a 19,99 & 276 & $3.807,7$ & 272 & $2.463,9$ \\
\hline De 20 a 49,99 & 2.053 & $57.875,7$ & 2.007 & $36.398,3$ \\
\hline De 50 a 99,99 & 1.194 & $64.620,7$ & 1.162 & $32.081,9$ \\
\hline De 100 a 199,99 & 201 & 23.954 .9 & 195 & $13.859,0$ \\
\hline De 200 a 499,99 & 68 & $18.768,7$ & 68 & 8.553 .7 \\
\hline De 500 a 999,99 & 21 & $12.402,0$ & 20 & $3.199,0$ \\
\hline De 1000 a 2.499 & 14 & $18.859,5$ & 13 & 4.300 .5 \\
\hline De 2500 a 4.999 & 3 & $8.100,0$ & 2 & $1.832,0$ \\
\hline De 5.000 ou mais & 2 & $10.420,0$ & 2 & $2.580,0$ \\
\hline
\end{tabular}

Fonte: elaboraça propria com base em dados preliminares do segundo censo nacional agropecuário (INE, 1987). 
Tabela 1.3. Evoluça da populaçao das áreas urbanas do Cantao Sao Carlos, Provincia Ichilo. Periodo 1976-1992.

\begin{tabular}{l|ll|l}
\hline Localidade & 1976 & 1992 & Taxa de Cresc. \\
\hline Villa Busch & 3135 & 8535 & $6,46 \%$ \\
(Yapacani) & & & \\
Sao Carlos & 2015 & 3219 & $2,97 \%$ \\
Santa Fé & 1681 & 4013 & $5,59 \%$ \\
San Juan & 1263 & 2630 & $4,69 \%$ \\
\hline
\end{tabular}

Fonte: Elaboraçao propria com base em INE, 1992: 39 
Tabela. I.4. Santa Cruz: participaçao no PIB nacional, periodo 1970-1980 (em milhoes de pesos:1970)

\begin{tabular}{llll}
\hline Ano & Bolivia & Santa Cruz & $\%$ \\
\hline 1970 & 12.374 & 2.019 .2 & 16.3 \\
1971 & 12.985 & 2.210 .3 & 17.0 \\
1972 & 13.732 & 2.373 .9 & 17.3 \\
1973 & 14.668 & 2.677 .8 & 18.2 \\
1974 & 15.563 & 2.811 .7 & 18.1 \\
1975 & 16.353 & 2.998 .8 & 18.3 \\
1976 & 17.469 & 3.296 .1 & 18.9 \\
1977 & 18.064 & 3.463 .7 & 19.2 \\
1978 & 18.628 & 3.475 .9 & 18.7 \\
1979 & 19.007 & 3.574 .0 & 18.8 \\
1980 & 19.161 & 3.591 .0 & 18.7 \\
\hline \hline
\end{tabular}

Fonte: Arrieta 1990: 195 
Tabela 1.5. Preços do Arroz e valor da diária (Em dólares constantes de 1985)

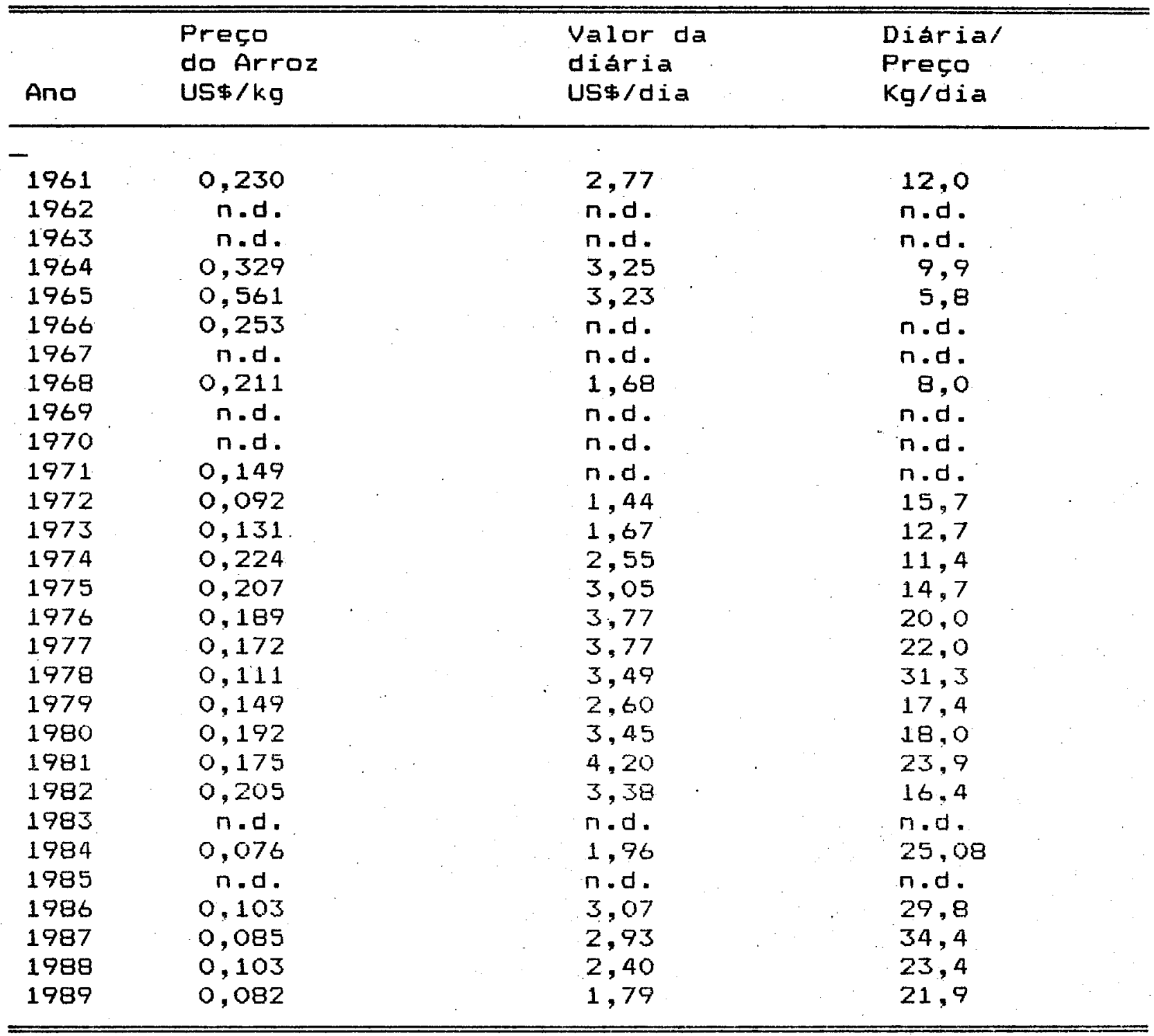

Fonte: Thielle 1991: 38 
Tabela I.6. Moradias segundo carência de serviços básicos na cidade de Sarita Cruz (Porcentagens)

\begin{tabular}{|c|c|c|c|c|c|c|}
\hline \multirow{2}{*}{$\begin{array}{l}\text { AREA DE } \\
\text { RESIDENCIA }\end{array}$} & \multicolumn{2}{|c|}{ SERVISOS } & \multicolumn{3}{|c|}{ NAOO DISPONÍVEIS NA MORADIA } & \\
\hline & $\begin{array}{l}\text { Bantiei- } \\
\text { ro }\end{array}$ & Agua & Esgato & $\begin{array}{l}\text { Energia } \\
\text { eletrica }\end{array}$ & $\begin{array}{l}\text { s/agua, } \\
\text { banheiro } \\
\text { e esgato }\end{array}$ & $\begin{array}{r}\text { Sem } \\
\text { nada }\end{array}$ \\
\hline $\begin{array}{l}\text { TOTAL } \\
\% \text { sobre o } \\
\text { total mor. }\end{array}$ & $\begin{array}{r}51.846 \\
43,2\end{array}$ & $\begin{array}{r}53.810 \\
44,9\end{array}$ & $\begin{array}{c}89.605 \\
74.7\end{array}$ & $\begin{array}{r}17.467 \\
14,6\end{array}$ & $\begin{array}{r}35.585 \\
31,3\end{array}$ & $\begin{array}{r}11.911 \\
9.9\end{array}$ \\
\hline $\begin{array}{l}\text { Total } \\
\text { Ate anel } 2 \\
\text { Entre anel } \\
2-4 \\
\text { Fora anel } 4\end{array}$ & $\begin{array}{r}100,0 \\
10,6 \\
39,7 \\
49,7\end{array}$ & $\begin{array}{r}100,0 \\
6,6 \\
34,1 \\
59,3\end{array}$ & $\begin{array}{r}100,0 \\
1,6 \\
50,5 \\
47,9\end{array}$ & $\begin{array}{r}100,0 \\
2,4 \\
9,4 \\
88,2\end{array}$ & $\begin{array}{r}100,0 \\
3,4 \\
38,1 \\
58,5\end{array}$ & $\begin{array}{r}100,0 \\
2,3 \\
7,6 \\
90,1\end{array}$ \\
\hline
\end{tabular}

Fonte: VARGAS 1991: $\underline{50}$ 
Tabela I.7. Populaçao segundo niveis de pobreza, tamanho e renda media mensal em US\$ por familia e "per cápita"

\begin{tabular}{|c|c|c|c|c|c|}
\hline \multirow[t]{2}{*}{ NIVEL DE POBREZA } & \multicolumn{2}{|c|}{ POPULACÃO } & \multirow{2}{*}{$\begin{array}{l}\text { TAMANHO } \\
\text { PROMEDIO } \\
\text { POR FAM. }\end{array}$} & \multicolumn{2}{|c|}{$\begin{array}{l}\text { RENDA PROMEDIO } \\
\text { MENSAL EM US\$ }\end{array}$} \\
\hline & Número & $\%$ & & FAMIL. & PER CAP. \\
\hline TOTAL & 556.937 & 100,0 & 4,81 & 215,0 & 152,5 \\
\hline $\begin{array}{l}\text { Indigentes } \\
\text { Pobres }\end{array}$ & $\begin{array}{r}36.688 \\
244.121\end{array}$ & $\begin{array}{r}6,6 \\
43,8\end{array}$ & $\begin{array}{l}6,95 \\
5,66\end{array}$ & $\begin{array}{r}76,8 \\
134,6\end{array}$ & $\begin{array}{l}11,1 \\
23,6\end{array}$ \\
\hline Nao-potres & 276.128 & 49,6 & 4,10 & 277,5 & 74,3 \\
\hline
\end{tabular}

Fonte: VARGAS $1991: \underline{70}$ 
APENDICE 2 


\title{
A botânica e os métodos de produça da coca
}

\begin{abstract}
0 que se conhece por "coca" e uma planta pantropical do tipo arbustivo. A altura varia, dependendo da regiao e da especie ou variedade, de so centimetros até mais ou menos 2,5 metros. A familia das Erythroxylaceas pertencem ao genero Erythroxylum e compreende aproximadamente 250 especies. De todas as espécies que crescem na America, perto de 200, so duas sao cultivadas: a Erythroxylum novogranatense, com uma variedade mais importante, a $E$. novogranatense var Truxillense; $e$ a Erythroxilum Coca 1 am, com uma gama de variedades ainda nao bem identificadas (CANELAS E CANELAS 1983, P.57):
\end{abstract}

A distribuiçao geográfica das duas especies cultivaveis de coca, devido as suas preferencias ecologicas, e diferente. A E. Coca, tamben conhecida como "coca huanuco" ou "boliviana", na atualidade e a mais importante do ponto de vista economico e se encontra distribuida ao longo das vertentes orientais dos Andes, desde a Bolivia até o Equador, incluindo tamben parte da Amazônia. 
A coca e uma planta que quando cultivada na forma tradicional a para o consumo humano, precisa enorme cuidado no seu cultivo e ainda mais na deshidrataçao e empacotamento. Do ponto de vista dos cultivadores tradicionais da regiao dos Yungas, o calor excessivo estimula o crescimento da planta com exagerada precocidade, mas em detrimento da qualidade da folha, isto é, de seu conteúdo de cocaina.

Do ponto de vista do consumidor tradicional, a qualidade da folha da coca esta associada com a sabor doce que por sua vez se relaciona ao baixo conteúdo de cocaina. E por esta razao que este tipo de consumidor prefere a coca produzida nos Yungas de La Paz aquela produzida no Chapare ou Yapacani. Obviamente, a preferencia é inversa no caso dos interessados na obtenço de cocaina. Segundo QuIROGA (1990, p.88) a coca dos Yungas tem aproximadamente um rendimento $30 \%$ menor de cocaina do que a coca do Chapare ou Yapacani

Aparentemente, na regiao dos Yungas, os metados de cultivo tem sofrido poucas mudanças ao longo do tempo. Primeiramente se faz germinar as sementes en pequenos canteiros, onde as mudas jovers permanecem entre 12 e 18 meses antes de serem transplantadas para o lugar definitivo. 
Nos morites escarpados dos Yungas de La Paz, planta-se a coca em terraços, seguindo uma curva de nivel. A boa preparaça dos terraços reduz a necessidade de capinas, permitindo ao mesmo tempo uma utilizaçao mais eficaz da terra cultivável.

Com um cuidado apropriado, as plantas podem produzir durante um periodo de 20 a 40 anos, e em casos excepcionais até um século; contudo, os melhores rendimentos se obtém entre o terceiro e sexto ano. A colheita é efetuada a cada 4 meses nos rungas e a cada 3 meses no Chapare e Yapacani.

Ds métodos de produção no chapare e Yapacani diferem em boa medida dos descritos para os Yungas. devido as diferenças de clima e de topografia. Sendo os primeiros mais planos, se prescinde dos terracos, plantando as mudas de coca sobre sulcos adubados com materia organica e cinza. o intervalo entre plantas é de aproximadamente 30 a $45 \mathrm{~cm} e$ de um metro entre sulcos. Com freqüencia. se consorcia com mandioca, pratica nao adotada pelos agricultores dos Yungas

mo Notas de campo obtidas, atraves de entrevistas informais com agricultores en visitas as regices produtoras de coca, entre 1987 e 1989 


\section{A coca e a nutriçao}

No citado estudo de CARTER a MAMANI (p.438), foi constatado que os horarios de mastigaço da coca nåo precedem as refeiçoes. Na realidade, săo posteriores a elas. o que na cultura ocidental urbana e uma sobremesa, para os camponeses é a hora do "acul1i", um tempo de avaliaçáo e cálculo de tarefas por fazer. Na opiniao deles, o "aculli" da coca, mais do que abrandar a fome, facilita a digestao.

\section{Eles acrescentam que nas suas pesquisas} nao conseguiram detectar a coca como uma necessidade básica, mas como un luxo que acompanta as cerimonias de maior transcendencia e que atua no incentivo ao trabaliho. Esta apreciaça e coincidente com a do antropdlogo peruano E. MAYER (1983, p.214-5): "... as artigos de luxo så bens relativamente escassos que produzem satisfaça e prazer pessoais. Sao utilizados năo só como autogratificaçao, mas como veiculas no estabelecimento de laços de amizade e boa vontade quando sao presenteados e compartilhados na convivencia social. Existe, portanto, uma atitude diferente 
em relaçæo a esses tipos de bens. Na nossa cultura ensinamos aos nossos filhos esta atitude ao aconselhar-lhes que nao devem desfrutar seus "artigos" sozintios, senzo campartilhar com irmåos e amigos. Mas tambem vemos que os nossos filhos convertem esse "artigo" em meio de intercambio: um deles o troca por um piao e outro utiliza para ganhar-se un aliado permanente. Portanto, estes beris tem um valor de gratificaçao pessoal e un valor social. En tal sentido se emprega a coca no mundo andino".

De acordo com DUKE et alli (1975), comparando as folhas de coca com so produtos vegetais latino-americanos, estas folhas resultam ser mais ricas en calorias, proteinas, carboidratos, fibra, cinza, cálcio, fosfora, ferro, vitamina $A$, vitamina $B 2$, vitamina $E$ e riboflavina. A coca apresenta um conteudo mais baixo de oleo, agua, niacina e acido ascorbico. Portanto, a ingestao de 100 gramas de folhas de coca ultrapassaria a quantidade diária recomendada, para o homem ou mulher adultos, em termos de cálcio, ferro, fósforo e as vitaminas assinaladas acima. 